PONTIFÍCIA UNIVERSIDADE CATÓLICA DO RIO DE JANEIRO

\title{
A importância de uma gestão profissional para 0 desempenho dos clubes de futebol- Estudo de caso do CR Flamengo
}

\section{Daniel Miller Tenenbaum}

Trabalho de Conclusão de Curso

Centro de CIÊNCIAS SOCIAIS - CCS

DEPARTAMENTO de ADMINISTRAÇÃO

Graduação em Administração de Empresas 
Daniel Miller Tenenbaum

A importância de uma gestão profissional para o desempenho dos clubes de futebol Estudo de caso do CR Flamengo

Trabalho de Conclusão de Curso

Trabalho de Conclusão de Curso, apresentado ao programa de graduação em Administração da PUC-Rio como requisito parcial para a obtenção do titulo de graduação em Administração.

Orientadora: Lygia Magacho

Rio de Janeiro, Novembro de 2015. 


\section{Agradecimentos}

Primeiramente, compartilho meu sentimento de alegria por concluir mais uma etapa importante da minha vida. Finalizo a minha Graduação, sendo capaz de superar muitos obstáculos. Em seguida, agradeço as pessoas que contribuíram para que isso fosse possível:

Aos meus pais, Suzanne e Vitor, pelo amor incondicional, formação e apoio incansável a toda minha trajetória.

Às minhas irmãs, Eduarda e Rafaela, pelo fato de existirem e tornarem meus dias mais completos e felizes.

Aos meus avós, Alexandre (in memorian) e Genny, Jacob e Fany, meus tios, André e Sonia, Fernando e Ylana, e meus primos, Rachel, Michel, Alessandra e Carolina, pelos ensinamentos, companheirismo, amor e amizade.

Em especial, à tia Ylana, pela paciência, disponibilidade e colaboração ao longo de toda a faculdade. Sem ela, a realização desse sonho seria inviável.

À minha namorada, Carolline, pela ajuda em diversas disciplinas do curso, paciência nas ocasiões que abriu mão da minha companhia e pela assistência em todos os momentos.

À orientadora, Prof ${ }^{a}$. Lygia Magacho, pelas contribuições, disponibilidade e parceria ao longo da elaboração deste trabalho.

Ao meu staff, Jô, Dedê e Jorge, pelo suporte, atenção e carinho no meu dia a dia.

Aos meus amigos, pela força e companheirismo ao longo da minha vida.

Aos entrevistados, em especial os profissionais do CR Flamengo, pela disponibilidade em fornecer as informações.

Por fim, a todos aqueles que fizeram parte dessa jornada acadêmica com um conselho, uma dica, um abraço, uma pergunta ou um sorriso. 


\section{Resumo}

Tenenbaum, Daniel Miller. A importância de uma gestão profissional para o desempenho dos clubes de futebol - Estudo de caso do CR Flamengo. Rio de Janeiro, 2015. Número de páginas p. 83 Trabalho de Conclusão de Curso Departamento de Administração. Pontifícia Universidade Católica do Rio de Janeiro.

O presente trabalho tem como principal objetivo analisar como uma gestão profissional dos clubes esportivos influencia nos resultados de um time de futebol. Além disso, comparar uma administração já consolidada, do Real Madrid CF com a do CR Flamengo, iniciando seu processo de profissionalização. Através de pesquisas em livros, sites, artigos, bem como, pesquisas com gestores e jogadores do Flamengo foi possível avaliar o atual cenário do clube no que diz respeito às estratégias e práticas do dia a dia. Assim, sugerindo como as ações do Real Madrid CF e as expectativas dos jogadores podem melhorar o desempenho do clube.

Palavras- chave

Futebol, Gestão Profissional, Planejamento estratégico, Cultura Organizacional, Real Madrid CF, CR Flamengo, Gestores, Jogadores.

\section{Abstract}

Tenenbaum, Daniel Miller. The importance of professional management to the performance of soccer clubs - Case Study of CR Flamengo. Rio de Janeiro, ano. Número de páginas p. 83 Trabalho de Conclusão de Curso - Departamento de Administração. Pontifícia Universidade Católica do Rio de Janeiro.

This study aims to analyze how professional management of sports clubs influence the results of a soccer team. Also, compare a consolidated administration of Real Madrid CF with the CR Flamengo, starting its professionalization process. Through research in books, websites, articles, as well as research with managers and players of Flamengo was possible to evaluate the current situation of the club with respect to the strategies and practices of everyday life. So, can suggest how the actions of Real Madrid CF and expectations of players can improve the performance of the club.

Key-words

Soccer, Professional Management, Strategic Planning, Organizational Culture, Real Madrid CF, CR Flamengo, Managers, Players 


\section{SUMÁRIO}

1. O problema 1

1.1. Introdução 1

1.2. Objetivo Final 2

1.3. Objetivos intermediários do estudo 3

1.4. Delimitação do estudo 3

1.5. Relevância do estudo 3

2. Revisão da Literatura 4

2.1. O contexto atual do futebol brasileiro 4

2.2. Conceitos fundamentais 5

2.2.1. Gestão Profissional 5

2.2.1.1. Importância de uma gestão profissional em uma organização 6

2.2.1.2. Gestão Profissional em Clubes de Futebol 7

2.2.2. Planejamento Estratégico 8

2.2.2.1. Planejamento Estratégico em Clubes de Futebol 10

2.2.3. Cultura organizacional 11

2.2.4. Clima Organizacional 13

2.2.5. Comunicação 15

2.2.6. Liderança 16

2.2.6.1. Conceito de Liderança 16

2.2.6.2. Estilos de liderança e impactos no desenvolvimento da equipe 18

$\begin{array}{ll}\text { 2.2.7. Motivação } & 20\end{array}$

3. Metodologia 23

3.1. Tipo de Pesquisa 23

3.2. Pesquisa-Ação 23

3.3. Procedimentos e instrumentos de coleta de dados utilizados no estudo e Etapas de coleta de dados $\quad 24$

3.4. Fontes de informação selecionadas para coleta de dados no estudo 25

3.5. Limitações para o estudo 26

4. Análise e Resultados 27

4.1. Benchmarking Real Madrid 27 
4.1.1. Histórico 27

4.1.2. A estratégia utilizada 28

4.1.3. Panorama atual 32

4.2. Flamengo 34

4.2.1. Histórico 34

4.2.2. Visão dos gestores 34

4.2.2.1. Importância de uma gestão profissional 35

$\begin{array}{ll}\text { 4.2.2.2. Planejamento Estratégico } 36 & 36\end{array}$

4.2.2.3. Relacionamento com os jogadores $\quad 40$

4.2.3. Visão dos jogadores 43

4.2.4. Panorama Atual 52

4.3. Comparação entre Real Madrid e Flamengo 54

4.4. Comparação entre a visão dos gestores e jogadores do Flamengo 56

5. Conclusões 58

5.1. Sugestões e recomendações para novas pesquisas 59

$\begin{array}{ll}\text { 6. Bibliografia } & 60\end{array}$

7. Apêndices 66

7.1. Roteiro de Entrevista com Gestores do Flamengo 66

$\begin{array}{ll}\text { 7.2. Questionário para Jogadores } & 67\end{array}$

7.3. Transcrições das Entrevistas 69 


\section{Lista de Figura}

Figura 1: Pilares e objetivos estratégicos do Real Madrid 28

Figura 2: Ranking das maiores receitas dos clubes de futebol 2013/2014

\section{Lista de Gráficos}

Gráfico 1: Evolução das receitas do Real Madrid entre 2000 e 2005 em Euros

Gráfico 2: Quanto tempo joga profissionalmente? 43

Gráfico 3: Quanto tempo joga no Flamengo? 44

Gráfico 4: Conhece a história do Flamengo? 44

Gráfico 5: Objetivos e metas do Flamengo em 2015

Gráfico 6: As orientações são claras e objetivas? 45

Gráfico 7: O clube é aberto a receber e reconhecer as críticas, opiniões e contribuições de seus jogadores? 46

Gráfico 8: O jogador tem a responsabilidade de contribuir para o sucesso do clube?

Gráfico 9: Relacionamento entre os jogadores $\quad 47$

Gráfico 10: Estilos de liderança $\quad 47$

Gráfico 11: Insatisfação Jogadores 48

Gráfico 12: Fatores de motivação dos jogadores 49

Gráfico 13: Se sente realizado jogando futebol? 50

Gráfico 14: Satisfação com o salário $\quad 50$

Gráfico 15: O Flamengo é um bom lugar para trabalhar? 51

Gráfico 16: Avaliação da atual gestão do Flamengo 51

Gráfico 17: Evolução de receitas do Flamengo entre 2009 e 2014 em Reais 52

Gráfico 19: As 5 maiores receitas do Brasil em milhões de reais nos últimos 4 anos 53

Gráfico 18: As 5 maiores dívidas do Brasil em milhões de reais nos últimos 4 anos 


\section{O problema}

\subsection{Introdução}

Ao longo das últimas décadas, o esporte vem se desenvolvendo e se modificando de forma que passa a ser encarado como um negócio lucrativo para as partes envolvidas: clubes, jogadores, empresários, patrocinadores, sócios e cidades. Hoje em dia, o futebol é muito mais que um esporte, há toda uma indústria por trás de um jogo.

Quando o assunto é o futebol, o primeiro país que pensamos é o Brasil, "o país do futebol", que possui um altíssimo potencial de rentabilidade. Entretanto, em todo o mundo, o setor movimenta cerca de 250 bilhões de dólares, sendo que o Brasil representa menos de $1 \%$ de participação desse total (SEIXAS, 2011).

O brasileiro, desde seu nascimento, já tem uma relação muito próxima com o futebol, nomes inspirados em jogadores de futebol, a bola como primeiro brinquedo, adultos colecionando álbuns de figurinhas, tatuagens, entre outras ações que demonstram a paixão dos brasileiros pela bola. A partir dos gestos mais simples, podemos perceber o quanto o esporte está embutido no nosso dia-a-dia. Seja no cinema, teatro, músicas, livros, o futebol faz parte da formação social do brasileiro e da cultura do país.

"Posso morrer pelo meu time

Se ele perder, que dor, imenso crime

Mas se ele ganha, não adianta

Não há garganta que não pare de berrar."

(Samuel Rosa e Nando Reis, 1996)

Este trecho da música do Skank, "É uma partida de futebol", analisa de uma forma simples, mas muito correta como o esporte é visto no Brasil. O futebol se caracteriza por ser uma forma de linguagem aonde a sociedade pode expressar suas facetas emocionais, como, por exemplo, paixão, felicidade, tristeza, coragem, dor, entre outras. O brasileiro consegue se identificar com as questões oferecidas pelo jogo, as alegrias, as superações, e assim, relacioná-las com o cotidiano. Isso é perceptível em certas ocasiões, como a forma 
de se comunicar, já incorporamos ao nosso vocabulário frases típicas do futebol, como, por exemplo, quando fazemos algo de errado, falamos que "pisamos na bola" ou quando estamos em uma situação adversa, desvantajosa, falamos que "vamos virar o jogo".

Podemos concluir que mesmo em um país cercado por crises, o povo busca alegria no futebol. Portanto, esse esporte é uma paixão nacional e um elemento identificador do povo brasileiro.

Atualmente, podemos observar que o futebol formou um mercado de entretenimento, onde os jogadores se tornaram celebridades e ícones para o mundo todo. Nesse sentido, com o futebol se inserindo nessa indústria forma-se um setor competitivo e promissor entre os clubes e surge a necessidade da implementação de modelos administrativos visando aprimorar o seu desempenho.

Para os amantes do esporte é notável o desenvolvimento de práticas de gestão das entidades de futebol ao longo do tempo. Por exemplo, a fonte de receita dos clubes, antes basicamente composta por bilheteria e venda de jogadores, hoje em dia é composta por bilheteria, transferência de jogadores, programa de sócio torcedor, produtos personalizados com a marca do time, cotas de TV, patrocínios, entre outros.

Nesse processo de profissionalização podemos identificar clubes, principalmente alguns europeus, como Real Madrid, Barcelona e Manchester United, que já têm modelos de gestão bem definidos e profissionais. Entretanto, aqui no Brasil as entidades têm dificuldade em desenvolver e/ou implantar a gestão profissional. Além disso, é evidente que muitas organizações esportivas brasileiras são utilizadas como um sistema político e um instrumento de domínio no sentido de favorecer a defesa dos próprios presidentes e elites envolvidas, muitas vezes permanecendo com "cadeira cativa" por muito tempo (SEIXAS, 2011).

É diante deste cenário, que o presente trabalho pretende estudar como uma administração eficiente, com gestão profissional, planejamento estratégico e cultura bem definidos pode ser aproveitada por clubes brasileiros a fim de melhorar o desempenho de suas equipes, tanto em quantidade de vitórias como em resultados financeiros. Para tanto, o estudo utiliza como referência o caso do Real Madrid CF (benchmarking objeto de estudo) e pesquisa e compara com a atual gestão de futebol do C.R. Flamengo, que vem se profissionalizando nos últimos 2 (dois) anos.

\subsection{0bjetivo Final}

O presente trabalho se propõe analisar como uma gestão profissional dos clubes esportivos influencia na cultura e no clima de um time de futebol e na satisfação dos 
jogadores. Comparando a gestão consolidada de um clube europeu, Real Madrid CF, com a gestão do C.R. Flamengo, ainda iniciando seu processo de profissionalização.

\subsection{Objetivos intermediários do estudo}

Para complementar o objetivo principal, há alguns mais específicos que fazem parte deste estudo, sendo eles:

- Analisar a atual gestão praticada pelos clubes brasileiros de futebol;

- Identificar as vantagens e desvantagens de uma gestão profissional;

- Identificar como o planejamento estratégico em clubes de futebol é realizado e apóia a gestão profissional dos clubes;

- Identificar a influência da cultura e do clima organizacional nos jogadores e consequentemente nos resultados alcançados;

- Analisar o caso do Real Madrid CF e o caso do C.R. Flamengo;

\subsection{Delimitação do estudo}

Este trabalho está delimitado ao estudo da gestão profissional esportiva nos últimos 10 anos, já que se trata de um assunto recente no Brasil. Além disso, foram analisados dois clubes de futebol, o Real Madrid e o Flamengo. O caso do Real Madrid foi analisado a partir de 2001 até 2006, período em que o trabalho de reestruturação das estratégias do clube foi realizado. E o do Flamengo foi analisado a partir de 2013, ano que iniciou a gestão atual, focada na profissionalização da gestão do clube.

\subsection{Relevância do estudo}

Este estudo é importante para clubes esportivos em geral, e em especial para os clubes brasileiros de futebol, visto que nos últimos anos a gestão do esporte vem evoluindo para uma gestão profissional, com visão empresarial. Em função disso, esse trabalho pode despertar o interesse de alunos de administração, administradores, estudiosos de gestão estratégica, além de gestores dos clubes, patrocinadores e jogadores.

Com o estudo, os cartolas poderão aprimorar seus processos, e direcionar esforços para as ações principais, que impactam em resultados para o clube e que atendam as expectativas dos jogadores, motivando-os para o alcance de resultados. Os jogadores poderão usufruir de melhores benefícios proporcionados pela gestão profissional. 


\section{Revisão da Literatura}

\subsection{O contexto atual do futebol brasileiro}

O Brasil, como analisado anteriormente, tem uma população apaixonada pelo futebol e um clima muito favorável à prática desse esporte. Entretanto, depois da derrota de $7 \times 1$ do Brasil para a Alemanha, na semifinal da Copa do Mundo em 2014, muitas questões foram levantadas sobre o futebol brasileiro e a maneira como vem sendo conduzido.

Primeiro é relevante fazer uma análise sobre a CBF (Confederação Brasileira de Futebol), entidade máxima do futebol brasileiro. A sua principal atribuição é administrar o futebol brasileiro, seja criando regulamentos, campeonatos, seja cuidando da modernização e desenvolvimento do futebol brasileiro, seja aplicando penalidades a clubes.

Atualmente, o calendário brasileiro de futebol tem dois campeonatos de abrangência nacional, organizados pela CBF. São eles: "Campeonato Brasileiro" e "Copa do Brasil". O primeiro é dividido em quatro divisões, aonde as duas principais divisões, A e B, são disputadas em formato de "pontos corridos", onde todos os times jogam contra todos, ida e volta, ao longo de todo o ano. Já, a "Copa do Brasil" é disputada em formato de "mata a mata" por 86 clubes de todo o país. Além deles, ainda há campeonatos estaduais, organizados pelas federações de cada estado, cada um com formatação própria. (CBF.com.br, 2015)

Com a seleção brasileira como seu principal produto, a CBF conseguiu aumentar seus ganhos consideravelmente, de 263 milhões de reais para 519 milhões de reais nos últimos 5 (cinco) anos. (Extra.globo.com, 2015)

Porém, a Entidade se encontra em crise, com muitos casos de corrupção, com o presidente atual, Marco Polo Del Nero, supostamente envolvido em escândalos internacionais de propinas e uma CPI (Comissão Parlamentar de Inquerito) no Senado Federal para investigar irregularidades em contratos da CBF, a CPI do futebol. (Globo.com, 2015)

Nesse cenário, onde os cartolas da CBF estão mais preocupados em obter lucros para a organização do que desenvolver o futebol brasileiro, no final de 2013, alguns atletas criaram o movimento Bom Senso FC com o intuito de pressionar a CBF a promover mudanças nos campeonatos, com temporadas mais curtas, além de fair play nas finanças dos clubes, entre outras propostas. Hoje, o movimento já conta com mais de 1.000 atletas de futebol nacional. (BomSensoFC, 2015) 
A situação dos clubes brasileiros não é muito diferente, com práticas antiquadas de se administrar, estagnação de ideias e a grande maioria dos clubes muito endividados (como confirma o estudo feito pelo blog do Rodrigo Mattos, os 12 (doze) grandes clubes brasileiros possuem uma dívida de mais de 5 (cinco) bilhões de reais), torna-se impossível a modernização desses. (MATTOS, 2015)

O futebol brasileiro está em crise e uma das causas é a falta de uma gestão profissional. Esta afirmativa pode ser feita, pois analisando a evolução do futebol europeu é possível perceber o salto dado por clubes de futebol que adotaram a gestão profissional nos últimos 10 (dez) anos. A gestão profissional é um aspecto fundamental para que o futebol possa se desenvolver, não só nos clubes, mas também nas federações e confederações.

\subsection{Conceitos fundamentais}

\subsubsection{Gestão Profissional}

Para Sobral (2008), "gestão é um processo que consiste na coordenação do trabalho dos membros da organização e na alocação dos recursos organizacionais para alcançar os objetivos de uma forma eficaz e eficiente". Uma administração de sucesso consiste em obter ao mesmo tempo eficácia e eficiência na utilização dos recursos organizacionais, ou seja, escolher os objetivos certos e conseguir atingi-los, minimizando a utilização dos seus recursos (tempo, capital, pessoas, equipamentos).

Ainda segundo o autor, "os membros que têm como função guiar as organizações de forma a alcançar seu propósito são os gestores. Esses que decidem onde e como aplicar os recursos de forma a assegurar que a organização atinja seus objetivos".

Segundo Sobral (2008) as principais funções da administração são:

1) Planejamento: definir objetivos e desenvolver estratégias e ações para alcançálos;

2) Organização: determinar o que deve ser feito, como deve ser feito e quem deve fazer;

3) Dirigir: liderar e motivar os membros da organização;

4) Controlar: monitorar o desempenho para garantir que os objetivos sejam alcançados.

Uma gestão profissional contempla o estabelecimento de objetivos organizacionais e realimenta o processo contínuo da estratégia. Serra (2004) defende que empresas que buscam vantagem competitiva definem objetivos estratégicos, metas e são focadas em 
resultados. Ao se posicionarem estrategicamente as empresas adotam uma gestão profissional, com um dinamismo diferenciado, além de orientação aos resultados e às pessoas.

Segundo um estudo feito pelo Serviço Brasileiro de Apoio a Empresa (Sebrae) em 2011, aproximadamente $30 \%$ dos novos negócios falham nos dois primeiros anos de atividade, principalmente devido ao amadorismo gerencial, levando a falhas na gestão do negócio. (Sebrae, 2011)

\subsubsection{Importância de uma gestão profissional em uma organização}

Para Sobral (2008), independentemente do tipo de empresa é importante analisar que no mundo atual se vive em ambiente globalizado e em uma dinâmica de constante transformações. As principais mudanças e tendências impactam o dia-a-dia das empresas e trazem novos desafios aos gestores.

Chiavenato (2000) identifica quais serão os desafios da administração nas próximas décadas. Segundo ele, "mudanças rápidas e bruscas, o crescimento organizacional, a concorrência das demais organizações, o desenvolvimento tecnológico, os fenômenos econômicos da inflação, a internacionalização das atividades, a visibilidade e interferência da opinião pública" serão os principais desafios. O autor analisa que esses desafios farão com que as organizações atuais passem a lidar com a imprevisibilidade, descontinuidade e instabilidade, o que era incomum nas empresas do século XX. Portanto, novas formas e modelos de organização serão necessários bem como uma administração bem definida será imprescindível para a atualidade.

Sobral (2008) diz que para enfrentar esses desafios:

\footnotetext{
... os administradores precisam desenvolver uma nova visão para suas organizações, apostar na flexibilidade e rapidez de resposta, estar atentos à diversidade cultural, considerar ética e a responsabilidade social nas suas decisões, focalizar a estratégia na satisfação dos clientes e, acima de tudo, investir no treinamento e desenvolvimento contínuo do seu principal ativo: o capital humano de suas organizações. (SOBRAL, 2008, p.22)
}

Chiavenato (2000) afirma que todos esses desafios trarão uma consequência para a administração das organizações: a administração da incerteza. E com isso, segundo o 
autor, a gestão na sociedade moderna se torna ainda mais vital e indispensável para as empresas.

\subsubsection{Gestão Profissional em Clubes de Futebol}

Em 1998 foi criada a Lei n9.615 de 24 de março de 1998, mais conhecida como Lei Pelé, que tinha o objetivo de tornar obrigatória a transformação dos clubes associativos em clubes-empresas, ou seja, sociedades que visam lucros. (PLANALTO)

A expectativa no momento da criação desta lei era de que os clubes buscariam a direção de uma gestão mais efetiva, uma vez que teriam que perseguir suas próprias viabilidades econômico-financeiras, sob o risco de, no caso de insucesso, além de colocarem em risco suas próprias existências, seus dirigentes também responderiam com seus bens particulares, pelos prejuízos eventualmente causados. Isso tenderia a elevar o grau de responsabilidade, assertividade e comprometimento de seus dirigentes no que se refere à maneira de administrar o clube, além de, como empresa suas contas seriam fiscalizadas mais facilmente. (MATTAR, 2014)

Os clubes se manifestaram contra a essa exigência da lei, pois estão acostumados com a permissividade com que são tratados no modelo associativo, além do fator tributário, que deixariam de contar com uma série de isenções e benefícios fiscais no caso de alteração do modelo. E assim, a lei, teve seu texto original alterado, tornando não mais obrigatória, mas sim facultativa a adoção do modelo empresarial. (MATTAR, 2014)

\footnotetext{
Um clube de futebol que assuma o modelo de sociedade empresarial tende a ter impulsionada uma mudança contundente no comportamento e postura gerencial de seus dirigentes. (...) os clubes passam a viver uma realidade - em termos de ter uma postura orientada para negócios, praticar uma interface mais profissional para o mercado, buscar equilíbrio financeiro de suas operações, assumir riscos das decisões tomadas - muito semelhantes às enfrentadas com aquela enfrentada por empresas normais de outros setores, o que exigiria uma postura muito mais eficaz dos dirigentes. (MATTAR, 2014, p.75)
}

Entretanto, o mesmo autor diz que há controvérsias, uma vez que defende que uma boa gestão é representada por atributos sólidos, dentre os quais responsabilidade, assertividade e transparência. Não representa a realidade afirmar que só seria possível a mudança de conduta dos dirigentes por meio da adoção de um formato empresarial. Barcelona e Real Madrid, clubes associativos, praticam uma gestão moderna e invejável. 
Para o autor, o sucesso está na transparência da gestão praticada pelos dirigentes, independente da forma jurídica de clube-empresa ou não.

O futebol brasileiro ainda precisa de uma gestão mais profissional, com diretores remunerados, vinculados aos resultados e que atendam por seus atos. Este é um aspecto fundamental para que o futebol possa se desenvolver.

\subsubsection{Planejamento Estratégico}

Planejamento é um processo contínuo que contempla um conjunto de ações integradas, e orientadas para tornar realidade um objetivo futuro, contribuindo para a tomada de decisões de forma antecipada. Estas ações devem ser definidas considerando aspectos como: custos, prazo, qualidade, segurança, desempenho e outras condicionantes (SERRA, 2004).

Kotler (1999) propôs que: "O Planejamento Estratégico é uma metodologia gerencial que permite estabelecer a direção a ser seguida pela Organização, visando maior grau de interação com o ambiente". O mesmo autor explica que direção engloba: âmbito de atuação, macro políticas, políticas funcionais, filosofia de atuação, macro estratégia, estratégias funcionais, macro-objetivos, objetivos funcionais.

Planejamento Estratégico é uma ferramenta de gestão empresarial utilizada nas organizações. Oliveira (1991) considera como um instrumento relacionado à estratégia empresarial que contribui para o seu desenvolvimento e sustentação.

Para Serra (2004) planejamento estratégico é o instrumento que ordena o que se pretende que aconteça. $O$ autor ainda complementa afirmando que é o processo pelo qual acontecimentos futuros são antecipados, de forma que ações sejam implementadas para atingir os objetivos de uma organização.

A elaboração de um planejamento estratégico deve refletir o raciocínio estratégico de uma organização. Segundo Kotler (1999) um planejamento estratégico deve contemplar a missão e visão do negócio; análise do ambiente externo (oportunidades e ameaças); análise do ambiente interno (forças e fraquezas); formulação de estratégias; implementação; feedback e controle.

Serra (2004) define visão como sendo a "percepção das necessidades do mercado e os métodos pelos quais uma organização pode satisfazê-las". A visão se torna tangível com a definição da missão, que é a declaração das intenções e aspirações da organização. Segundo o mesmo autor é a razão de ser de uma organização.

Drucker (2006) defende que para alcançar o sucesso, cada organização deve definira sua missão. Serve de estrutura para uma organização, objetivando o alcance de seus 
objetivos. O autor alerta que a missão deve ser amplamente divulgada a todos os colaboradores da organização.

Organizações são sistemas abertos, que sofrem influências externas. A análise do ambiente externo contribui para a identificação de oportunidades e ameaças. De acordo com Chiavenato (2000), as condições externas impõem às empresas desafios e oportunidades. O autor exemplifica como fatores externos a concorrência ou competição; tendências políticas, sociais e culturais, que afetam a sociedade, em geral.

Serra (2004) exemplifica como fatores externos que influenciam os negócios os de origem econômica (taxa de juros, fontes de financiamento, política ambiental, inflação, dentre outros fatores de tributação); tecnológicos, políticos legais (política internacional do governo, regulamentação comercial e técnica); socioculturais (fatores demográficos, fenômenos de moda, hábitos de consumo e de compra).

Conforme Chiavenato (2003), o nível de ambiente externo de uma organização que contém componentes em geral com implicações relativamente específicas e imediatas para gerenciar a organização é o ambiente operacional. Ele é composto pelos seguintes componentes: clientes, concorrência, mão-de-obra, fornecedores e agências reguladoras.

Segundo Ferrell (2000), a análise do ambiente interno se refere à revisão das metas, objetivos e desempenho da organização; à revisão dos recursos organizacionais atuais e previstos e revisão dos problemas estruturais atuais e previstos. Os dados e informações podem ser coletados através de fontes internas, periódicos, livros e pesquisas.

Para Chiavenato (2000), a análise do ambiente interno permite uma análise dos pontos fortes e fracos de uma organização. Pontos fortes são as forças propulsoras da organização que promovem e facilitam o alcance dos objetivos da organização e os pontos fracos são os que impedem ou podem dificultar o seu alcance.

Serra (2004) define a implementação e execução da estratégia como um processo orientado para a ação e envolve as pessoas, o desenvolvimento de competências, orçamento, construção de cultura e liderança. E o autor ainda ressalta que para uma estratégia ser bem sucedida é imprescindível que a alta gestão da organização exerça liderança se empenhando nesse processo bem complexo.

De acordo com Harrison (2005), o Planejamento Estratégico envolve um processo incluindo as seguintes etapas:

Execução de uma análise do ambiente: é o monitoramento do ambiente organizacional para identificar os riscos e as oportunidades presentes e futuros. Nesse contexto, o ambiente organizacional encerra todos os fatores, tanto internos como externos à organização, que podem influenciar o progresso obtido através da realização de objetivos da organização. 
Estabelecimento de uma diretriz organizacional: há dois indicadores principais de direção para os quais uma organização é levada: a missão e os objetivos organizacionais. A missão é a finalidade de uma organização ou a razão de sua existência. Os objetivos são as metas das organizações. Há outros dois indicadores de direção que, as organizações estabelecem: a visão, que é o que as empresas aspiram a ser ou se tornar, e os valores, que retratam a filosofia que norteia a empresa a diferenciando das demais.

Formulação de uma estratégia organizacional: definida como um curso de ação visando garantir que a organização alcance seus objetivos. Formular estratégias é projetar e selecionar estratégias que levem à realização dos objetivos organizacionais.

Implementação da estratégia organizacional: esta quarta etapa o foco são as estratégias desenvolvidas, que emergiram de etapas anteriores ao processo de administração estratégica. Sem a implementação efetiva da estratégia, as organizações são incapazes de obter os benefícios da realização de uma análise organizacional, do estabelecimento de uma diretriz organizacional e da formulação da estratégia organizacional.

Controle estratégico: etapa concentrada no monitoramento e avaliação do processo de administração estratégica no sentido de melhorá-lo e assegurar um funcionamento adequado.

\subsubsection{Planejamento Estratégico em Clubes de Futebol}

Como em qualquer organização, os clubes de futebol podem valorizar mais a importância do planejamento no desenvolvimento de suas equipes, assim como, organizar seus processos e métodos focados em metas. Sendo assim, as ações serão realizadas de forma mais eficiente e com maior segurança. (BRUNORO E AFIF, 1997)

Para que equipes de futebol apliquem o planejamento estratégico é importante que estabeleçam sua missão, ou seja, definir a razão pela qual o clube existe e então identificar a visão, que vem a ser o que a entidade busca ganhar e para onde deve alocar seus recursos. Por último os valores, que são os ideais que regem as tomadas de decisões dos clubes, que necessitam ser definidos para que o planejamento estratégico tenha uma essência rígida. (BRUNORO E AFIF, 1997)

A função do planejamento é bem singular e deve traçar os objetivos que a instituição pretende alcançar, tanto dentro como fora de campo. Deve ficar compreensível qual a conduta que o clube deve assumir para atingir suas metas. (BRUNORO E AFIF, 1997)

O compromisso pelo planejamento deve ser dos gestores, e deve ser feito com a comissão técnica incluindo tudo o que diz respeito ao time durante uma temporada. As 
questões aqui envolvidas envolvem aspectos táticos, técnicos, físicos e psicológicos. (BRUNORO E AFIF, 1997)

Dessa forma, segundo Brunoro e Afif (1997), as finalidades devem ser divididas por todos e a parte de cada indivíduo deve ser bem esclarecida:

- Diretoria - entre diversas atividades, responder às necessidades e administrar o relacionamento com federações, confederações, torcedores, imprensa e outros clubes

- Comissão técnica - examinar as carências de cada profissional e fazer o planejamento;

- Atletas - Centrar a atenção na meta traçada depois da definição da premiação em caso de obtenção de títulos.

Estes são os aspectos essenciais para basear a definição de um planejamento estratégico em clubes de futebol.

\subsubsection{Cultura organizacional}

O conceito de cultura organizacional é complexo e são diversas as abordagens sobre o tema. Dentre os pesquisadores destacam-se Geertz (1989), que define cultura como o resultado da história particular de uma organização e de seus símbolos criados e mantidos pela sua liderança.

Schein (1986) defende que a cultura organizacional é como um padrão de pressupostos básicos compartilhados os quais o grupo adquiriu à medida que resolveu seus problemas de adaptação externa e integração interna. Complementa afirmando que é uma experiência que pode ser ensinada aos novos integrantes como forma correta de perceber, pensar e sentir-se em relação a esses problemas.

Segundo o mesmo autor pode-se enumerar como indicadores da cultura organizacional os seguintes atributos:

- Iniciativa individual: nível de responsabilidade, liberdade e independência das pessoas;

- Tolerância ao risco;

- Direção em relação aos objetivos e expectativas de desempenho;

- Integração das áreas para trabalharem de maneira coordenada;

- Contatos gerenciais: disposição dos gerentes para fornecer comunicações claras, assistência e apoio aos subordinados;

- Controle de regras e regulamentos que se usa para supervisionar e controlar o comportamento dos empregados; 
- Identidade: grau de identificação das pessoas com a organização como um todo;

- Sistema de recompensa e desempenho;

- Tolerância ao conflito e críticas;

- Padrões de comunicação entre os diversos canais hierárquicos.

Para Robbins (2004) a cultura organizacional se refere a um sistema de valores compartilhado pelos membros que diferencia uma organização da outra. Assim sendo, indivíduos com históricos diferentes, em diversos níveis da organização, descrevem a cultura organizacional em termos semelhantes.

Segundo Schein (1986), se a organização como um todo vivenciou experiências comuns, pode existir uma forte cultura organizacional que prevaleça sobre as várias subculturas das unidades. Grupos com experiência ocupacional semelhante tendem a desenvolver culturas próprias nas organizações, por exemplo: a cultura dos gerentes, a dos profissionais de marketing, de recursos humanos, dentre outros.

Para Robbins (2004) uma cultura começa com os costumes, rituais e tradições. Os fundadores de uma empresa são os responsáveis pelo impacto sobre a cultura inicial. As premissas dos fundadores serão fundamentais na definição da cultura. E depois de estabelecida, as práticas de gestão organizacional reforçarão a cultura.

Cultura organizacional tem diversas funções em uma organização. Segundo Robbins (2004) primeiramente desempenha o papel de definidora de fronteiras, isto é, distingue uma organização de outras. Em seguida, proporciona uma identidade para os membros da organização. Uma terceira função é ser uma facilitadora do comprometimento com algo que se sobrepõe aos interesses individuais. A quarta função é estimular a estabilidade do sistema social e por último o autor ressalta que ela atua como um mecanismo de controle orientando e dando forma aos comportamentos dos profissionais. Em resumo, a cultura organizacional define as regras do jogo.

Através da cultura - particularmente uma forte e efetiva - a organização define a realidade com a qual os seus membros irão viver. Inexiste juízo de valor, isto é, cultura boa ou ruim. Sua função principal é melhorar o comprometimento organizacional e aumentar a consistência do comportamento.

A maior consequência negativa da cultura organizacional é a de criar barreiras à mudança. Paradoxalmente, uma cultura forte pode produzir rigidez na organização, dificultando as necessárias mudanças para as novas condições. Outra disfunção da cultura é que ela pode criar conflitos dentro da própria organização, em especial quando os valores são compartilhados de forma inadequada, com ruídos na comunicação. (ROBBINS, 2004) 
No futebol, cada clube tem um estilo próprio, uma identidade. A cultura de cada clube brasileiro tem peculiaridades relacionadas à sua história, com valores e crenças bem particulares. Quando se trata de países diferentes, essas diferenças culturais são ainda maiores. O fundamental é o respeito a essas diferenças culturais das entidades e, em especial a compreensão dos valores que fazem parte da cultura de cada uma dessas organizações. (BASÁGLIA, 2012)

Atletas da categoria de base se inserem desde cedo na cultura de um clube, aprendendo seus valores e, em geral, têm mais amor à camisa e, por consequência, ascendência em relação ao grupo. Isto justifica ainda mais o forte investimento em jovens jogadores. (BASÁGLIA, 2012)

É chegado o momento dos clubes brasileiros entenderem que a cultura organizacional, quando bem gerenciada, pode ser um diferencial para o alcance dos resultados de um clube de futebol. O ideal para o futebol brasileiro é que os clubes invistam na formação e capacitação dos atletas e membros da comissão técnica, de forma que os recém-chegados pudessem assimilar a cultura do clube para o qual estão sendo contratados, fortalecendo o orgulho e a satisfação do trabalho diário. (BASÁGLIA, 2012)

A transmissão da cultura organizacional, por parte de um clube e sua assimilação por parte dos atletas, contribui para a geração de bons resultados aos clubes de futebol num curto espaço de tempo. O fato de se sentirem familiarizados com a cultura do clube pelo qual estão atuando possibilita o estabelecimento de um sentimento de pertencimento àquela organização, que refletirá no seu rendimento dentro de campo. Muitos clubes de futebol deixam de obter melhores resultados e mais lucratividade na venda de atletas com potencial por não darem a devida importância à sua cultura organizacional. (BASÁGLIA, 2012)

\subsubsection{Clima Organizacional}

Assim como acontece com o conceito de cultura organizacional, existem várias definições de clima organizacional. Para Bennis (1996) "clima significa um conjunto de valores ou atitudes que afetam a maneira pela qual as pessoas se relacionam uma com as outras, tais como: sinceridade, padrões de autoridade, relações sociais, etc."

Abbey \& Dickson (1983) definem como "a qualidade de um ambiente interno de uma organização, advinda do comportamento e conduta dos seus membros, servindo como uma base para interpretar a situação e agindo como uma fonte de pressão direcionando as atividades".

O clima organizacional é um indicador do grau de satisfação dos colaboradores de uma organização, com referencia aos aspectos da cultura ou realidade aparente da 
organização. Segundo Luz (2001), o clima retrata o grau de satisfação material e emocional das pessoas no trabalho, influencia profundamente a produtividade do empregado. Ele proporciona a possibilidade da empresa de atrair e reter funcionários competentes que realmente contribuam com os resultados desejados.

Segundo Robbins (2004), uma pessoa que encontra um clima positivo de desempenho pensará em fazer um bom trabalho com mais frequência e acreditará que os outros apoiarão o sucesso dele ou dela. Assim como, aqueles que encontrarem um clima de diversidade positivo se sentirão mais confortáveis em colaborar com seus colegas de trabalho independentemente do contexto demográfico. Entretanto, de acordo com o autor, uma mesma organização pode possuir vários climas em diferentes setores, mas possui uma única cultura.

A partir das definições dos diversos autores, pode-se concluir que clima organizacional é o reflexo do ânimo das pessoas, que predomina numa organização, em um determinado período, proveniente da cultura da organização, sendo refletido no ambiente que se apresenta. Os membros de uma organização e seus estados de ânimo são os indicadores do grau de qualidade desse ambiente, podendo ser mensurado por meio da percepção dos sentimentos, motivação e desempenho. O resultado desse clima afeta positiva ou negativamente, em determinado período, o comportamento das pessoas e o seu grau de satisfação em relação ao trabalho.

Para Chiavenato (2003) as dimensões do clima Organizacional são:

- Estrutura organizacional - dar liberdade ou definir limites de ação para as pessoas através de regras, regulamentos, autoridade, especialização etc.

- Recompensas - a organização pode criticar ou incentivar os colaboradores pelos resultados alcançados, sendo que quanto mais estímulo e incentivo melhor será o clima organizacional.

- Calor e apoio - a organização pode manter um clima de cooperação ou de negativismo, entretanto quanto melhor o companheirismo melhor será o clima.

- Responsabilidade - pode reprimir ou incentivar o comportamento das pessoas por meio da negação de iniciativa, restrição quanto à decisão pessoal etc.

- Risco - a situação de trabalho pode estimular no sentido de assumir novos desafios ou como protetora para evitar riscos, sendo que quanto maior o estímulo melhor será o clima.

- Conflitos - a organização pode estabelecer regras e procedimentos, gerenciando os conflitos por meio da confrontação. 
O mesmo autor defende que o clima organizacional tem grande influência na motivação, satisfação e desempenho sobre as pessoas e por meio de variações em algumas dessas dimensões pode ser criado diferentes climas.

Para Bittencourt (2008), as pessoas são as responsáveis pela composição do clima organizacional, portanto pode-se afirmar que os fatores externos (problemas de relacionamento familiar e social, condições de saúde, habitação e lazer, por exemplo) também podem influenciar o ambiente de uma organização. Ainda segundo o autor, alguns fatores internos nas organizações interferem diretamente no clima organizacional, dentre eles: conflitos pessoais; comunicação deficiente; falha na condução das interfaces dos processos de trabalho; sistema de funções gratificadas; grau de satisfação dos servidores; equipe desmotivada; falta de harmonia entre as áreas de trabalho; dificuldades de relacionamento entre líderes e liderados etc.

No futebol, diferentemente de outros setores, o clima organizacional é muito variável. Soriano (2010) analisa que é preciso ganhar sempre, porém nem sempre se pode ganhar. Além disso, ainda segundo o autor, a avaliação é feita semana por semana, partida por partida e não anual, como em uma empresa privada ou trimestral em uma de capital aberto. E ainda, essa avaliação é pública, onde qualquer pessoa considera ter o direito e o conhecimento suficiente para emitir juízo de valor sobre o trabalho do atleta. Assim, percebemos que o clima organizacional de um clube de futebol é diretamente relacionado ao desempenho dentro de campo.

\subsubsection{Comunicação}

Para Robbins (2010) "a comunicação precisa incluir a transferência e a compreensão do significado. A comunicação deficiente é provavelmente a principal fonte de conflitos interpessoais no trabalho".

A habilidade de comunicação é uma competência essencial do líder, que deve transmitir com clareza e assertividade a sua mensagem. Castellani (2012) defende que a comunicação é um dos elementos que mais influenciam a liderança, ou seja, para que um jovem atleta se sinta seguro para fazer a sua atividade, terá que ser esclarecida de forma clara e perceptível. $O$ fato de o atleta se sentir apoiado e motivado pelo treinador, determinando uma boa comunicação, eleva o seu rendimento e desempenho.

Segundo Robbins (2010), a comunicação tem quatro funções básicas: controle, motivação, expressão emocional e informação.

A comunicação age no controle do comportamento das pessoas, também facilita a motivação por esclarecer aos funcionários o que 
deve ser feito, qual a qualidade de seu desempenho e como melhorá-lo se estiver abaixo do esperado. Para muitos funcionários, a comunicação possibilita a expressão emocional de sentimentos e a satisfação de necessidades sociais. E a função final da comunicação é facilitar a tomada de decisões, proporcionando informações de que as pessoas precisam para tomar decisões ao transmitir dados para que se identifiquem e avaliem alternativas. (ROBBINS, 2010, p.326)

Além disso, Robbins (2010), afirma que a comunicação pode fluir em sentido vertical, sendo subdividida em ascendente ou descendente e, também, sentido horizontal.

A comunicação descendente, segundo o autor, é a que flui dos níveis mais altos para os mais baixos. É usada pelos gestores e líderes que se comunicam com os funcionários para atribuir tarefas, fornecer instruções de trabalho, informar políticas e procedimentos. $O$ canal pode variar, tanto oral, face a face, quanto e-mails, correspondências.

A comunicação ascendente, segundo o autor, é utilizada para fornecer feedback aos gestores, mantém os dirigentes informados acerca de como os funcionários se sentem em relação ao trabalho, ao colega e à organização em geral. De preferência o canal para esse tipo de comunicação é o face a face.

Já, a comunicação lateral, segundo o autor, se dá entre os membros de um mesmo grupo, de um mesmo nível. Esse tipo de comunicação economiza tempo e facilita a coordenação.

E por último o autor traz algumas barreiras para a comunicação eficaz, que são elas: a filtragem; percepção seletiva; sobrecarga de informação; emoções; idioma; silêncio; medo de comunicação; diferenças de gênero; e a comunicação 'politicamente correta'.

\subsubsection{Liderança}

\subsubsection{Conceito de Liderança}

Liderança tem sido definida e caracterizada por diversos autores oriundos de áreas que variam da psicologia à administração. Quando pesquisado tem sido associada à motivação, trabalho em equipe, orientação para resultados e desenvolvimento de pessoas.

Inexiste uma única definição que aborde o tema de forma plena. Por vezes o termo liderança é confundido com administração e/ou gestão. Entretanto, temos que distingui-los. Liderança se refere ao estabelecimento de direções por meio do desenvolvimento de uma 
visão do futuro; engajamento de pessoas inspirando-as a superar obstáculos visando tornar esta visão uma realidade em um determinado período de tempo (KOTLER, 1999). Enquanto que a administração diz respeito às estruturas organizacionais, planejamento, gestão e monitoramento de resultados.

Para Hersey e Blanchard (1986) liderança é quando alguém influencia o comportamento de um indivíduo ou de um grupo, visando qualquer objetivo final, seja pessoal ou de terceiros, coerentes ou não com os objetivos organizacionais.

Um das definições de Bergamini (1994) é que "o líder é aquele que inicia e facilita a interação entre os membros do grupo".

A liderança pode ser exercida por pessoas que não ocupem cargos de liderança. Naturalmente, um indivíduo pode desempenhar o papel de líder. Segundo Hunter (2004) "liderança representa a sua capacidade de influenciar pessoas a agir".

Maxwell (2008) defende o conceito de liderança de forma abrangente: disposição de assumir riscos, desejo apaixonado de fazer a diferença, se sentir incomodado com a realidade, assumir responsabilidades, enxergar as possibilidades de uma situação enquanto outros focam apenas nas dificuldades, disposição de se destacar no meio da multidão, inspirar outras pessoas com uma visão da contribuição que podem oferecer, integração do coração da mente e da alma, além da coragem e vontade de transformar sonho em realidade.

Drucker (1996) defende a existência de seguidores como princípio indispensável para ser um líder: Para ele, "a única definição de líder é alguém que possui seguidores. Algumas pessoas são pensadoras. Outras, profetas. Os dois papéis são importantes e muito necessários. Mas, sem seguidores, não podem existir líderes".

Frente aos conceitos relatados pode-se concluir que, a liderança é um processo, que envolve duas ou mais pessoas, provocado intencionalmente pelo líder sobre seus liderados.

No futebol, a liderança está associada à transmissão de informação e à forma como é transmitida, quer seja pelos gestores, treinadores, ou jogadores. Entretanto, a percepção e o entendimento da informação podem não ser os mais corretos, conduzindo a diferentes tipos de comportamentos. A coesão de grupo é um fator importante na medida em que todos os elementos da equipe estão focados em atingir os objetivos delineados pelo líder. Assim, caso o líder não tenha a habilidade de comunicação mais adequada, ou até mesmo se não se integrar convenientemente, a comunicação dos objetivos à equipe pode falhar, sendo um dos fatores de insucesso.

Em um grupo de futebol a liderança não é exercida somente pelo treinador e capitão, qualquer membro pode assumir certo grau de liderança, seja ou não indicado formalmente para uma posição ou 
um posto, e que demais funcionários e outros jogadores também exerçam, em suas devidas proporções, as funções de líder. (CASTELLANI, 2012, p.435)

O autor pesquisou o tema e identificou que diversos funcionários têm e/ou podem vir a ter características de liderança. No grupo de dirigentes há os que se destacam nessa habilidade. Da mesma forma, isto ocorre com os funcionários da assessoria de imprensa, equipe médica e no grupo de jogadores. Entretanto, o papel desses líderes é variado como, por exemplo, na comissão técnica a liderança é exercida pelo treinador.

\subsubsection{Estilos de liderança e impactos no desenvolvimento da equipe}

Autores e pesquisadores sobre o assunto defendem que há diversos estilos de liderança. A seguir, as principais características de cada estilo e como influenciam no desenvolvimento das equipes e no alcance dos resultados.

Segundo Fachada (2003) o líder autocrático determina as metas e diretrizes sem a participação do grupo, inclusive não dá liberdade de escolha em relação às ferramentas e técnicas na execução das tarefas. É um estilo de liderança que limita a liberdade dos seguidores a escolherem quais tarefas Ihes interessam e com quais membros irão trabalhar. O líder se coloca de forma inflexível e dominador, e liderados têm sua criatividade limitada pela postura diretiva do líder. A consequência deste estilo está relacionada à ausência de iniciativa da equipe, além de provocar um distanciamento do grupo em suas relações interpessoais podendo comprometer o trabalho em equipe e o alcance dos resultados.

O líder liberal dá liberdade para os seguidores tomarem decisões. O grupo decide sobre a divisão das tarefas e com quem irão trabalhar $O$ líder não se demonstra tão presente, resultando numa produção insatisfatória. Muito tempo é perdido com discussões e questões pessoais. Fachada (2003) denomina este estilo como o pior a ser adotado.

E o líder democrático é aquele que torna as decisões parte da discussão do grupo. Seus seguidores esboçam técnicas para o alcance das metas propostas. O líder procura ser um membro igual aos outros, sendo objetivo e fazendo críticas apoiado em fatos. É um estilo que promove um bom relacionamento entre os seguidores, transformando o ritmo do trabalho em algo suave, seguro e de qualidade, mesmo na ausência do líder. Segundo Fachada (2003), o líder adota o papel de apoiador e orientador e os resultados são alcançados com mais qualidade.

É importante ressaltar que cada estilo tem características bem distintas. Inexiste um estilo de liderança perfeito, pois depende da situação que o líder enfrenta. Segundo Hersey 
e Blanchard (1986), a relação entre o líder e seus seguidores é baseado na otimização, pois deve haver um alinhamento entre a maturidade do grupo para o alcance de resultados juntamente com o estilo de liderança mais adequado para esta situação. Nesta teoria são estudos de liderança: a persuasão, o compartilhamento, a delegação e a determinação. Dentro desta abordagem, o resultado positivo está diretamente ligado à habilidade do líder em se adequar a um estilo alinhado à maturidade do indivíduo para oferecer recursos e ambiente positivo necessário para o seguidor desenvolver e realizar suas tarefas da melhor maneira.

Hersey e Blanchard (1986) sugerem um modelo de liderança capaz de avaliar o líder em diferentes situações. Nas avaliações de um líder, duas variáveis são importantes para este julgamento, a primeira é como o líder se comporta (como se orienta para cumprir trabalhos e como se relaciona com seus subordinados) e a segunda é a maturidade dos seguidores (como desempenham para cumprir as tarefas solicitadas).

Os autores complementam afirmando que algumas pessoas não são capazes de se adequar a diferentes estilos e adotam um único estilo. Já outros, conseguem adotar dois ou três estilos a depender da situação. Líderes mais flexíveis têm potencial de serem mais eficazes em diferentes situações. Esta habilidade do líder em variar adequadamente ao estilo é denominada adaptabilidade de estilo, de acordo com a Liderança Situacional.

Segundo os autores, liderança é um processo e não, um traço ou característica que o líder tem. É um evento que ocorre entre o líder e seus seguidores e implica na qualidade do relacionamento entre eles. Envolve influenciar um grupo de indivíduos em torno de um objetivo comum. O engajamento dos seguidores fortalece a equipe como um todo e cria um ambiente positivo, que impactará diretamente nos resultados.

Além da liderança situacional há duas teorias contemporâneas, segundo Robbins (2004), que são a Carismática e a Transformacional. House (1977) foi um dos primeiros autores a explicar o impacto psicológico dos líderes carismáticos nos seguidores. São líderes que incitam o poder e a afiliação visando concretizar a visão em função das exigências da missão. Para o autor esses líderes se constituem modelo e objeto de identificação dos seguidores. São identificados como: corajosos, autoconfiantes e moralmente convictos.

Já a liderança transformacional é um processo que transforma as pessoas, segundo Lowe e Gardner (1993). Está relacionada com as emoções, ética, padrões e objetivos de longo prazo. Inclui a avaliação das motivações dos seguidores, satisfazendo as suas necessidades. É um estilo de liderança que motiva os seguidores a fazerem mais do que as expectativas, transcendam seus próprios interesses para o bem da equipe ou da organização. 


\subsubsection{Motivação}

Robbins (2004) define motivação como sendo uma disposição para fazer algo, condicionada pela capacidade dessa ação satisfazer uma necessidade do indivíduo. Referese à necessidade como sendo uma deficiência física ou psicológica que faz um resultado parecer atraente. Quando uma necessidade não é satisfeita gera tensão.

São diversas as teorias sobre motivação, dentre elas a mais conhecida, a Teoria da Hierarquia das Necessidades, de Abraham Maslow na década de 1950. Segundo o autor, cada ser humano tem uma hierarquia de cinco necessidades, sendo elas: (ROBBINS, 2004)

- Fisiológicas: fome, sede, abrigo, sexo e outras necessidades corporais.

- Segurança: proteção e segurança contra danos físicos e emocionais.

- Sociais: afeição, amizade, aceitação.

- Estima: fatores internos (respeito próprio, autonomia e realização) e fatores externos (status, reconhecimento e atenção).

- Autorrealização: crescimento, conquista pessoal e autodesenvolvimento.

À medida que cada necessidade é atendida, a próxima se torna a dominante. Aos poucos o indivíduo se move para o topo dessa hierarquia de necessidades. Maslow ressaltou que nenhuma necessidade é satisfeita em sua totalidade.

Frederick Herzberg, em 1959 propôs a Teoria dos Dois Fatores, Higiene-Motivação. Segundo Herzberg os fatores higiênicos afetam diretamente a insatisfação com o trabalho, sendo eles a qualidade da supervisão; a remuneração; políticas da organização; condições físicas do trabalho; relacionamento com os colegas e segurança no emprego. Já os motivacionais afetam a satisfação com o trabalho, pois são as oportunidades de promoção e de crescimento pessoal; reconhecimento; responsabilidade e realização. (ROBBINS, 2004)

As Teorias Comportamentais sobre Motivação são a Teoria das Necessidades de McClelland; Teoria da Fixação de Objetivos; Teoria do Reforço; Teoria da Equidade e Teoria da Expectativa. (ROBBINS, 2004)

David McClelland, em 1961 e sua equipe concluíram que são três os principais motivos ou necessidades de trabalho. São eles: necessidade de realização (busca da excelência); necessidade de poder (necessidade de fazer as pessoas se comportarem de maneira que não é própria do comportamento delas) e necessidade de associação (desejo de relacionamentos interpessoais próximos e amigáveis). (ROBBINS, 2004)

Segundo Robbins (2004), a Teoria da Fixação de Objetivos propõe que as intenções podem ser fonte principal de motivação no trabalho. Objetivos específicos contribuem para o aprimoramento do desempenho e que objetivos difíceis, se aceitos, acarretam melhor desempenho do que metas mais fáceis de serem alcançadas. 
Para o mesmo autor, a Teoria do Reforço vê o comportamento como causa do ambiente. Ignora o interior do indivíduo, se concentra no que acontece quando realiza qualquer ação.

E Robbins (2004) também cita que de acordo com a Teoria da Equidade os trabalhadores avaliam o esforço que se dedicaram a uma atividade e o resultado que obtiveram. Reconhece que as pessoas não estão preocupadas com a recompensa e sim, com a relação entre quantidade e a recebida pelos outros.

A Teoria da Expectativa, segundo Robbins (2004) defende que a força da tendência para agir de determinada forma depende da força da expectativa de que a ação trará um resultado esperado e da atração que o resultado exercerá sobre a pessoa. O foco dessa teoria são três variáveis: atração (importância que se dá ao resultado ou à recompensa potencial que será alcançado no trabalho); relação desempenho-recompensa (grau em que o indivíduo acredita que determinado nível de desempenho levará à obtenção do resultado esperado) e relação esforço-desempenho (probabilidade do indivíduo de que uma quantidade específica de esforço o conduzirá ao desempenho).

Para o mesmo autor, todas essas Teorias têm premissas relevantes, mas é essencial que um líder reconheça as diferenças individuais, individualizando as recompensas e vinculando ao desempenho, assegurando que os resultados serão alcançados. É importante motivar as pessoas de forma diferenciada, considerando os impactos e resultados que se pretende.

Marcos Chitolina, ex-diretor de futebol do Grêmio, explica como motivar um jogador:

Eu comparo um jogador com a motivação de um vendedor. Um vendedor, um representante comercial, a motivação dele é ganhar mais, é vender mais. E o jogador, a motivação dele, quanto mais ele jogar, melhor ele apresentar, mais ele vai ganhar. Mesma coisa depende dele. Agora, depende também, parte dele, grande parte eu diria dele, mas depende também em dar a estrutura para ele. Não adianta botar um jogar por exemplo, que tenha motivação, que tem potencial, no meio de um time "falido". Aí ele vai sucumbir junto. Então temos que criar uma estrutura de companheirismo, de atletas, um grupo que essa motivação que ele tem, ela junte com os demais jogadores e ai sim, faça um grupo motivado. E, dentro de um grupo pode ter jogadores motivados e jogadores desmotivados. Temos que resgatar os que estão desmotivados, para junto dos motivados. Isso é papel da direção, é papel de quem trabalha no futebol, nosso papel e da comissão técnica, do treinador e dos seus auxiliares. Isso funciona. $O$ jogador tem a sua motivação, mas 
temos que mexer nela. Temos que buscar a motivação dele para ele botar para fora. Se deixar a motivação do jogador só dentro dele, não acontece. (Site Queroserjogador.com.br, 2014)

Correia (2013) cita algumas medidas que podem motivar um jogador de futebol, como, por exemplo: um discurso motivador, uma compensação financeira por vitória, e em determinados casos, a troca no comando. 


\section{Metodologia}

\subsection{Tipo de Pesquisa}

A pesquisa realizada trata-se de um estudo de caso, de natureza descritiva e exploratória. Este método foi adotado por ser o mais adequado, segundo Yin (2001) para analisar situações em que se colocam questões do tipo "como" e "por que" e quando o pesquisador tem pouco controle sobre os fenômenos em questão por conta da contemporaneidade e do contexto da vida real.

O estudo de caso representa uma maneira de investigar um determinado assunto empírico seguindo-se procedimentos especificados, contribuindo para a compreensão de fenômenos individuais, organizacionais, sociais e políticos. (YIN, 2001)

Foram adotadas as pesquisas quantitativa e qualitativa, em função do objeto de estudo e dos objetivos definidos. A pesquisa quantitativa é apropriada para medir tanto opiniões, atitudes e preferências como comportamentos. Já a pesquisa qualitativa permite a análise de variáveis, um estudo da complexidade de um problema e a identificação de processos dinâmicos vividos por grupos, de forma a ampliar a compreensão das questões comportamentais (RUIZ, 1991).

Como unidade de análise foi escolhido o Clube de Regatas do Flamengo e como benchmarking o Real Madrid Futebol Clube.

Para o Referencial Teórico foi realizada uma pesquisa bibliográfica, com base em livros, artigos e reportagens.

\subsection{Pesquisa-Ação}

A participação do autor do trabalho como um dos jogadores do time CR Flamengo possibilitou a identificação da oportunidade de realizar um estudo de caso utilizando os conceitos da pesquisa-ação.

A pesquisa-ação surgiu nos anos 40 , como "um processo de espiral que envolve três fases: planejamento, tomada de decisão e encontro de fatos sobre o resultado da ação" (LEWIN, 1946, apud FRANCO, 2005) 
A pesquisa-ação é um tipo de pesquisa com base empírica na qual o pesquisador e participante do problema estão envolvidos diretamente no modo cooperativo ou participativo (THIOLLENT, 1988)

O papel do pesquisador, segundo o mesmo autor, é:

-Ser ativo nos problemas, avaliações e ações;

-Estabelecer comunicação com os atores;

-Ser flexível perante as situações e ao ambiente estudado;

-Ser capaz de reconhecer as características de cada situação;

-Manter a imparcialidade perante os fatos.

Melo (1988) diz que o pesquisador na pesquisa-ação assume um papel ativo de participante observador. Neste sentido, o trabalho caracteriza-se como uma pesquisa-ação, uma vez que o pesquisador é jogador do time e participa ativamente como ator da organização estudada.

\subsection{Procedimentos e instrumentos de coleta de dados utilizados no estudo e Etapas de coleta de dados}

Cooper e Schindler (2002) definem a pesquisa em administração como "uma investigação sistemática que fornece informações para orientar as decisões empresariais". Cada vez mais as técnicas e métodos analíticos contribuem para uma maior compreensão de seus princípios básicos.

A fase de coleta de dados objetiva a obtenção de informações da realidade (RUDIO, 1986).

Para a realização do referencial teórico foram consultados livros, artigos, teses de doutorado. Todas essas pesquisas bibliográficas foram importantes para o maior aprofundamento sobre o tema em questão como também contribuiu para a elaboração do roteiro de entrevistas feitas durante a fase de pesquisa de campo.

Foi analisado como benchmarking o time de futebol espanhol Real Madrid, com base em livros e artigos, a fim de conhecer, consolidar e analisar as principais estratégias que o clube desenvolveu de 2001 a 2006 para alavancar o valor de sua instituição no mercado.

Como fontes primárias foram realizadas entrevistas semiestruturadas com os principais gestores da organização CR Flamengo. As entrevistas foram realizadas no mês de outubro de 2015 e tiveram duração em média de trinta minutos.

Foram entrevistados os principais responsáveis pela gestão do Clube de Regatas do Flamengo. O vice-presidente de futebol, Gerson Biscotto; o CEO, Fred Luz; e o técnico Oswaldo de Oliveira. 
O roteiro contemplou perguntas base com o objetivo de obter informações sobre a gestão implementada nos últimos 2 anos, assim como a obtenção de informações passiveis de cruzamento com as informações levantadas junto aos jogadores (pesquisa quantitativa)

Conforme citado, as entrevistas foram realizadas no período de Outubro de 2015, no Estado do Rio de Janeiro, através de meios presenciais. No capítulo 4 serão transcritos os principais trechos para analise e conclusão do estudo.

Além disso, foi realizada uma pesquisa quantitativa com os jogadores do Flamengo, através de um questionário fechado, que tem como objetivo entender um pouco das expectativas e experiências desses jogadores diante da nova gestão do clube. Vale ressaltar que antes da aplicação do questionário foi realizado um teste com dois exjogadores do time com o objetivo de validar o entendimento das perguntas e eliminar possíveis dúvidas no momento da respostas.

A aplicação ocorreu no período de outubro de 2015, no Estado do Rio de Janeiro. Foram distribuídos 23 questionários, onde a aplicação foi por meio da plataforma do Google. Os jogadores responderam o questionário durante a concentração para um jogo do Campeonato Brasileiro, ou seja, período em que o atleta fica em um hotel, descansando para o próximo jogo. Dessa forma, conseguiam se concentrar ao fornecer as respostas, e assim, todos foram respondidos corretamente, sendo todos aceitos para análise. Após a coleta de dados, todas as informações foram compiladas para análise dos resultados e conclusões.

\subsection{Fontes de informação selecionadas para coleta de dados no estudo}

Para o Referencial Teórico foram utilizadas diversas bibliografias com variados autores, como, por exemplo, Chiavenato, Drucker, Mattar, Robbins, Sobral. Na análise do benchmarking, Real Madrid FC, foi utilizado um artigo dos autores Callejo e Forcadell do ano de 2006.

As entrevistas foram feitas com gestores do C.R. do Flamengo. Com o atual VicePresidente, Gerson Biscotto, com o CEO, Fred Luz e com o técnico Oswaldo de Oliveira.

Os questionários foram realizados com 23 jogadores, todos do time principal do CR Flamengo.

A interpretação dos dados foi realizada após a aplicação das entrevistas e dos questionários.

O tratamento dos resultados deve ser significativo e válido. Assim sendo, as informações podem ser interpretadas, através de quadros de resultados, figuras e modelos, 
de acordo com os objetivos propostos ou que apontem descobertas inesperadas (BARDIN, 2004).

A análise foi realizada através da interpretação dos dados obtidos na pesquisa de campo, relacionando-os com os conceitos levantados na revisão bibliográfica.

\subsection{Limitações para o estudo}

A realização de um estudo de caso, segundo Gil (2002) pode levar a algumas objeções quando aplicado, como a falta de rigor metodológico, pois para a realização do estudo de caso não foi definido procedimentos metodológicos rígidos. Assim, podem ter sido frequentes os vieses nos estudos de caso, os quais podem ter comprometido a qualidade dos resultados.

Outra objeção refere-se à dificuldade de generalização. Existe, também, a objeção referente ao tempo destinado à pesquisa, alega-se que os estudos de caso demandam muito tempo para serem realizados e que frequentemente seus resultados tornam-se pouco consistentes. Neste caso, o tempo destinado a esta pesquisa foi relativamente curto em função da proximidade do pesquisador com o objeto de estudo. (GIL, 2002).

A existência de poucos livros e documentação formal sobre a gestão profissional de clubes de futebol, bem como a limitação de informações históricas sobre a gestão dos clubes, Real Madrid FC e CR Flamengo dificultaram a comparação com outras épocas e gestões dos clubes.

E por se tratar de um método que envolve entrevista e a participação dos entrevistados, existe um limitante de interesse e de possibilidade de inverdades. 


\section{Análise e Resultados}

\subsection{Benchmarking Real Madrid}

É notório que o futebol europeu, assim como a sua gestão, está mais desenvolvido do que os demais do mundo, por isso escolheu-se aprofundar o estudo sobre esse benchmarking.

\subsubsection{Histórico}

Até o ano de 2000, o clube oscilou entre bons e maus momentos. Real Madrid F.C. tem mais de 110 anos de história e o futebol é a sua principal atividade. Sempre com bons elencos, grandes astros do futebol, o Real foi nomeado pela FIFA (Fédération Internationale de Football Association) como o melhor time de futebol do século XX. Entretanto, a entidade passou por um período de 32 anos sem conquistar a Liga dos Campeões, considerada a principal competição da Europa. (Realmadrid.com, 2015)

Nas eleições presidenciais do clube em 2000, o então presidente Lorenzo Sanz era o favorito, pois o clube tinha conquistado a Liga dos Campeões por duas vezes (1998 e 2000) em sua gestão, acabando com o jejum do clube. Entretanto, Florentino Pérez, focado no discurso de uma crise financeira muito grande e uma má administração, foi eleito naquele ano. (CALLEJO E FORCADELL, 2006)

A partir do mandato de Florentino, o clube iniciou a sua mudança estratégica. Seu principal objetivo era fazer com que o clube virasse "a melhor empresa esportiva na Europa", com uma instituição rentável e livre de dívidas. Desde então, o Real Madrid conseguiu se reestruturar e, assim, se equilibrar financeiramente se tornando hoje em dia, segundo um estudo feito pela revista "Forbes" em 2014, a equipe com maior valor de mercado entre os principais esportes do mundo. Os objetivos que gostariam de alcançar eram, além da conquista de títulos, um desempenho fora das quatro linhas que encantasse. E assim foi feito. (CALLEJO E FORCADELL, 2006) 


\subsubsection{A estratégia utilizada}

No Real Madrid, a transformação estratégica está relacionada à chegada de Florentino Pérez à presidência, em 2000. O principal objetivo era fazer com que o clube virasse "a melhor empresa esportiva na Europa", com uma instituição rentável e livre de dívidas. (CALLEJO e FORCADELL, 2006)

$\mathrm{Na}$ época, havia a necessidade por uma adoção de um novo modelo de negócios nos clubes de futebol devido a uma crise evidente na geração e crescimento da renda. Perante essa situação, a nova gestão estratégica do Real Madrid foi baseada nos seguintes pilares: o esportivo, o marketing e a estratégia social. (Imagem 1) Em qualquer caso, toda a visão estratégica do clube está focada na base de um duplo objetivo: sucesso econômico e sucesso esportivo. No entanto, dentro desse modelo, o clube considerava que era impossível de alcançar sucesso esportivo sem a obtenção de um bom desempenho econômico e, vice e versa. (CALLEJO e FORCADELL, 2006)

Figura 1: Pilares e objetivos estratégicos do Real Madrid

REAL MADRID STRATEGY

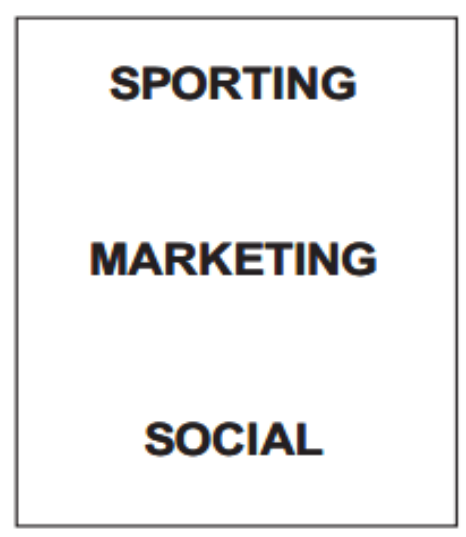

\section{OBJECTIVES}

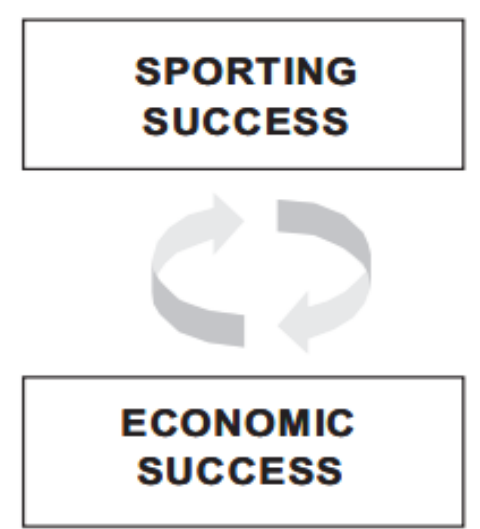

Fonte: Callejo e Forcadell, 2006

1) Esportivo:

A estratégia esportiva estava baseada em dois principais campos de ação: contratar jogadores com um impacto significativo de mídia, e promover jovens jogadores, a partir do trabalho das categorias de base. Ao contratar os melhores jogadores, além de aumentar a qualidade técnica de seu elenco, conseguiria obter um importante impacto na imprensa, podendo explorar a publicidade, aumentando seu valor de marca. Ao mesmo tempo, o Real 
Madrid visava promover para o seu time profissional, time principal, os jovens de suas categorias de base, os quais contêm valores e identidade do clube, e assim, investiram ainda mais no desenvolvimento desses jovens. (CALLEJO e FORCADELL, 2006)

\section{2) Social:}

A estratégia social do Real Madrid consiste em três aspectos: gestão de sócios do clube; política de imagem pública, articulada através da sua fundação; e promover um modelo de comportamento pacífico entre seus espectadores, eliminando toda a violência. (CALLEJO e FORCADELL, 2006)

Em primeiro lugar, o clube tem uma política de transparência nas informações no que diz respeito aos seus membros, além do cuidado na proteção de seus direitos. Os membros deram uma excelente avaliação à instituição (O clube informou que a partir de uma base de aproximadamente 82.000 membros, 97 por cento acharam que eles foram bem tratados por seu clube). (CALLEJO e FORCADELL, 2006)

Em segundo lugar, o Real Madrid tenta transmitir uma imagem pública de solidariedade e compromisso com a sociedade, fundamentalmente, através de sua fundação. Na época, o clube era embaixador da UNICEF (Fundo das Nações Unidas para a Infância), com preocupações em atividades de integração social e de caráter educativo, e colaborações em uma grande variedade de programas em todo o mundo para arrecadar fundos para ajudar a aliviar desastres naturais e outras tragédias. (CALLEJO e FORCADELL, 2006)

Finalmente, o confronto em um jogo de futebol está limitado somente dentro do campo de futebol e não nas arquibancadas. Isto levou o clube a estabelecer um programa de reeducação de seus torcedores o que levou a uma redução enorme no número de atos violentos dentro do estádio. (CALLEJO e FORCADELL, 2006)

3) Marketing:

No que diz respeito à estratégia de marketing do clube, a prioridade do Real Madrid era promover a exploração de sua marca, transformando os seus torcedores em clientes fiéis de seus produtos e serviços. O clube considerava que a marca era seu melhor ativo e por isso seria a melhor garantia para o clube no futuro. A utilização da marca fazia parte de um plano comercial bem planejado e desenvolvido que seguia essas principais estratégias (CALLEJO e FORCADELL, 2006):

a) Contratação de grandes jogadores: $O$ clube negociava com grandes estrelas do futebol, como, por exemplo, David Beckham, Figo, Ronaldo, os quais possuíam grandes impactos midiáticos e, assim, explorava a imagem desse jogador. 
b) Desenvolvimento de parcerias internacionais: a exploração do Real Madri não se limitou à Espanha. O clube procurou desenvolver parcerias internacionais para exploração de sua imagem ao redor do mundo. Como, por exemplo, Pegaso no México, Platia no Japão e Citic Conglomerate na China.

c) A exploração da marca em mercados emergentes no futebol. Os principais mercados emergentes do futebol eram e são o sudeste da Ásia (China, Japão e Coréia do Sul), o mundo árabe, e a Índia. Estes mercados eram e são praticamente inexplorados, assim os torcedores nessas áreas serão facilmente capturados, e com isso, tornando-se fãs fiéis. Para obter esse objetivo, o Real Madrid realizou pré-temporadas em viagens internacionais, especialmente na Ásia.

d) Patrocínio: o Real Madrid assinou contrato com um patrocinador principal, a Siemens IC Mobile. Além desse, assinou pacotes secundários de patrocínios com empresas como Pepsico, Audi, Adidas. Esse sistema de patrocínio era baseado em um sistema de parcerias aonde as instituições geravam uma sinergia buscando conquistar novos mercados estratégicos.

e) Novas tecnologias: o clube utilizou uma estratégia multicanal para explorar a sua imagem. Utilizou novas tecnologias baseadas na Internet, onde fornecia informações na sua página da Web e incentivava a venda online. Além disso, também focou na transmissão de informações do clube para telefones celulares, assinando contrato com a empresa de telecomunicações Telefônica.

f) "Real Madrid FanCard": o objetivo desse cartão é para ser um meio de gestão do clube com seus torcedores na Espanha e no mundo todo, projetado para fortalecer a fidelidade desses fãs. Esses titulares do cartão contaram com uma assinatura gratuita da revista Hala Madrid (grosso modo, "Vamos Madrid!"), descontos em lojas e produtos do clube, bem como prioridade na aquisição de bilhetes para os jogos.

g) Venda de produtos: primeiro, com a contratação de grandes estrelas do futebol, as vendas de camisas do time cresceu exponencialmente. Esta situação permitiu ao clube renegociar e aumentar o seu contrato com as marcas esportivas. Além disso, o clube também tinha um programa de licenciamento de produtos em níveis nacionais e internacionais.

h) Distribuição e comercialização: o clube se utilizou de dois tipos de estabelecimento para vender seus produtos, lojas próprias e franquias. O foco está na expansão da marca no país e fora dele.

Além dessas estratégias, esportivo, social e marketing, o clube se preocupou em melhorar a gestão do modelo tradicional do futebol. Historicamente, a indústria do futebol 
era baseada na exploração do evento esportivo, aonde a geração de renda a partir desta fonte era muito restrita, uma vez que, por um lado, os estádios possuem capacidades limitadas em termos de número de espectadores, e por outro, o mercado dos direitos televisivos e audiovisuais estavam em declínio. (CALLEJO E FORCADELL, 2006)

A gestão tradicional pode ser dividida nas seguintes categorias: exploração do estádio em si, junto com os torcedores e da transmissão desses jogos através da mídia de televisão.

a) Estádio / Torcedores

No ano de 2000, o clube promoveu uma renovação profunda no estádio do Real Madrid, Santiago Bernabéu, tendo em vista a completa exploração do mesmo. Este plano permitiu um aumento de receita de US\$28.5 milhões entre as temporadas de 2000-2001 e 2004-2005. Esse crescimento não está ligado ao aumento de taxas de adesão dos torcedores, e sim à melhoria na gestão das áreas VIP do estádio. (CALLEJO E FORCADELL, 2006)

O clube percebeu que poderiam explorar comercialmente o estádio o ano todo, tendo jogo de futebol ou não. No dia de uma partida, as receitas eram normalmente geradas por ingressos ou os serviços dentro do estádio como bares, lojinhas etc. Então, o clube criou pacotes turísticos com tudo incluído para torcedores VIP, desde ingresso para o jogo até serviços como hotéis de luxo e limusine. (CALLEJO E FORCADELL, 2006)

Outra medida criada foi limitar o número de pacotes de ingresso por temporada (prática comum na Europa, aonde os torcedores compram um pacote, dando direito ao ingresso para todos os jogos do time na temporada), assim, limitando 60.000 pacotes e restando aproximadamente 20.000 lugares (capacidade do estádio aproximadamente 80.000 torcedores) para torcedores ocasionais assistirem o jogo. O raciocínio era que esses torcedores ocasionais gastam mais com produtos e serviços do clube. (CALLEJO E FORCADELL, 2006)

Além disso, criaram um serviço inovador para esses clientes, que possuíam o pacote da temporada, permitindo que esses devolvessem seus ingressos caso não fossem utilizar, para que o clube revendesse, e assim, o torcedor ganhava desconto para a renovação de seu pacote no ano seguinte. Tiveram um retorno de aproximadamente US\$180 mil. (CALLEJO E FORCADELL, 2006)

Fora dos dias das partidas, o clube organizou dois tipos de visitas turísticas, a visita para a sala de troféus e um tour pelo estádio. Além disso, criou todo um serviço para empresas, as quais podiam comprar camarotes para dias de jogos, ou para somente fazer reuniões ali. Também, construíram dois restaurantes dentro do estádio, sendo um temático e o outro de alto nível. (CALLEJO E FORCADELL, 2006) 
b) Exploração da TV

As transmissões de televisão significam atingir um número muito maior de espectadores, permitindo que o clube ganhe um retorno sobre os direitos televisivos. $\mathrm{Na}$ época, o Real Madrid recebia cerca de US\$65 milhões por temporada. Em 2003, o clube tomou total controle sobre seu canal de televisão, o "Real Madrid TV", assim possuindo uma renda estimada de US\$ 7,2 milhões, incluindo assinaturas, publicidade e acordos. (CALLEJO E FORCADELL, 2006)

\subsubsection{Panorama atual}

A partir dessa renovação da estrutura do clube com o alinhamento de suas finanças, o clube só cresceu e a tendência é que cresça cada vez mais. No inicio do mandato de Pérez, as receitas do clube eram de 137.9 milhões de Euros, já no final, cresceram para 275.7 milhões de euros, como mostra o gráfico abaixo: (Deloitte.com, 2015)

\section{Gráfico 1: Evolução das receitas do Real Madrid entre 2000 e 2005 em Euros}

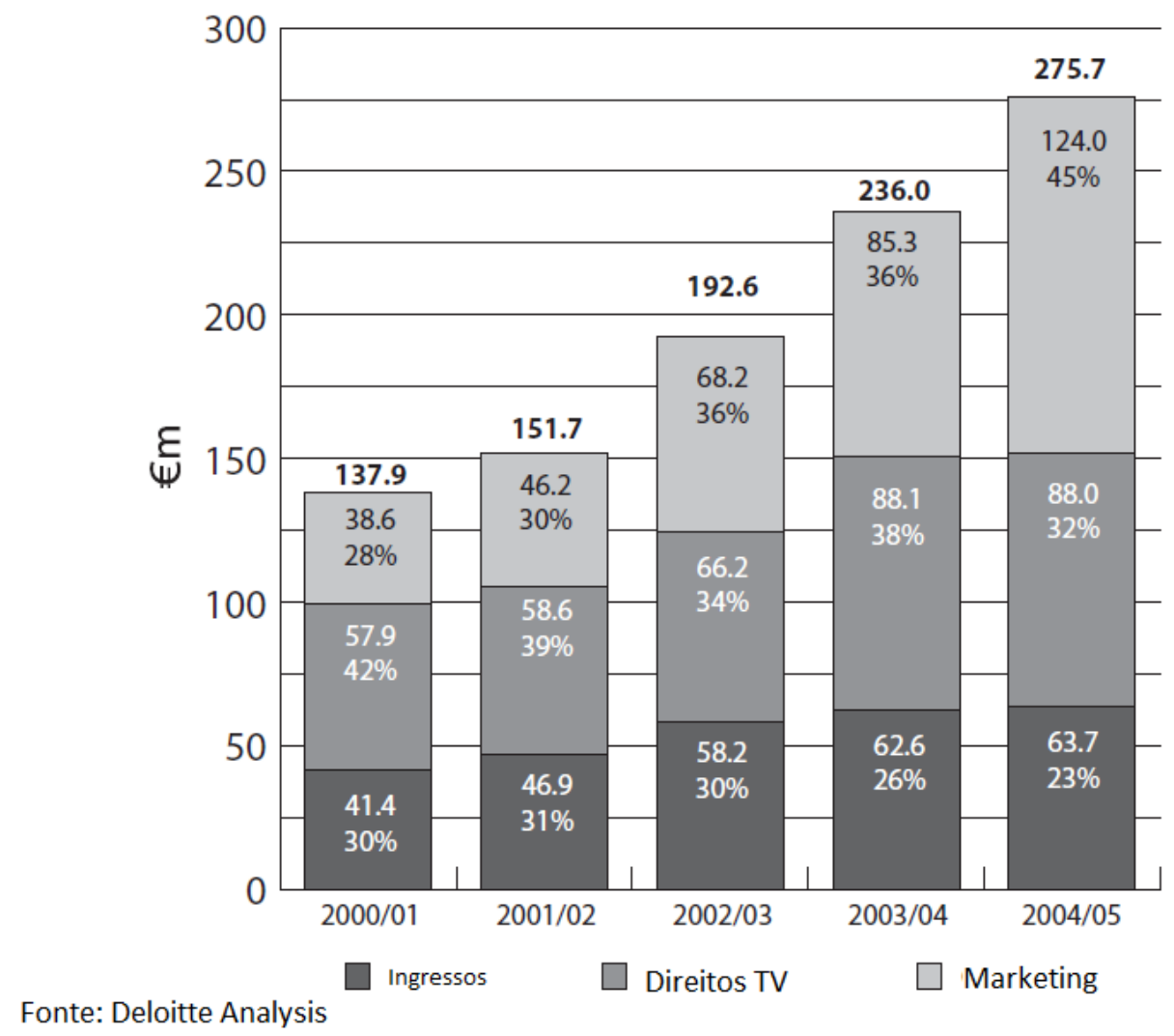

Segundo informação da Football Money League, publicada pela consultora Deloitte, atualmente o Real Madrid é o clube que lidera o ranking de receitas de todos os outros no mundo. Segundo informa a Deloitte, em ingressos o Real Madrid obteve 113,8 milhões de euros. Em transmissões televisivas e na UEFA Champions League, alcançou os 204,2 
milhões de euros, 15,9 milhões de euros a mais que no ano anterior, e em marketing o Real Madrid rendeu 231,5 milhões de euros, mais 20 milhões do que no ano anterior. (Site Deloitte.com, 2015)

Figura 2: Ranking das maiores receitas dos clubes de futebol 2013/2014

\begin{tabular}{ccc} 
POSIÇÄO & CLUBE & $\begin{array}{c}\text { RENDIMENTOS } \\
\text { MILHÕES } € \\
\text { TEMP. 13/14 }\end{array}$ \\
\hline 1 & Real Madrid & 549,5 \\
\hline 2 & Man. United & 518,0 \\
\hline 3 & Bayern Munique & 487,5 \\
\hline 4 & Barcelona & 484,6 \\
\hline 5 & PSG & 474,2 \\
\hline 6 & Man. City & 414,4 \\
\hline 7 & Chelsea & 387,9 \\
\hline 8 & Arsenal & 359,3 \\
\hline 9 & Liverpool & 305,9 \\
\hline 10 & Juventus & 279,4 \\
\hline
\end{tabular}

\section{Fonte: Deloitte.com}

Além desses ótimos resultados financeiros, o Real Madrid vem conquistando bons resultados dentro de campo também, como a conquista da décima Liga dos Campeões da Europa.

Portanto, como visto na análise acima, pode-se observar a importância de um planejamento estratégico junto com uma gestão profissional para um clube futebol. 


\subsection{Flamengo}

\subsubsection{Histórico}

O Clube de Regatas do Flamengo é o maior clube do Brasil no que diz respeito ao número de torcedores. Segundo uma pesquisa feita pelo jornal Lance junto com o lbope, o clube conta com aproximadamente 33 milhões de torcedores. (Lancenet.com.br, 2014)

Possuindo 120 anos de história, já contou com a presença de grandes ídolos no seu elenco, como Zico e Ronaldinho Gaúcho. O principal esporte é o futebol, porém o clube conta com diversas modalidades olímpicas, como, por exemplo, o remo e o basquete.

O Flamengo era conhecido pelo histórico de completa desorganização financeira. Entretanto, em 2013, a chapa liderada pelo presidente Eduardo Bandeira de Mello foi eleita com um discurso de reorganizar as contas rubro negras, pautando-se pelos princípios de austeridade financeira, responsabilidade fiscal, planejamento, ou seja, tornando profissional a gestão do clube.

Desde então, o Flamengo vem conseguindo se reestruturar e, assim, se equilibrar financeiramente se tornando hoje em dia um exemplo de administração no cenário brasileiro. Esse ano foi o grande vencedor do prêmio Brasil Sport Market, que reconhece as melhores práticas esportivas no país. O clube levou os troféus de "Melhor Gestão", "Transparência Financeira", e ainda teve seu atual CEO, Fred Luz, eleito o melhor do futebol brasileiro. Isso demonstra que fora das quatro linhas, o clube está se desenvolvendo. Entretanto, o que vem sendo questionado é o resultado dentro de campo, que não está acompanhando esse crescimento organizacional. (Flamengo.com.br, 2015)

\subsubsection{Visão dos gestores}

Foram realizadas três entrevistas em profundidade com gestores do departamento de futebol do Flamengo:

- Gerson Biscotto- Vice-Presidente de Futebol do Flamengo

- Fred Luz - CEO do Flamengo

- Oswaldo de Oliveira - Técnico do Flamengo

A partir das respostas coletadas, pode-se conhecer um pouco mais sobre a realidade e as estratégias do clube que são apresentadas e analisadas a seguir. 


\subsubsection{Importância de uma gestão profissional}

O início desta atual reestruturação está ligada à chegada do Eduardo Bandeira de Mello á presidência. Eduardo, formado em Administração de Empresas na UFRJ (Universidade Federal do Rio de Janeiro), trabalhou durante 35 anos no BNDES (Banco Nacional de Desenvolvimento Econômico e Social). Junto a ele, executivos de peso como, Luiz Eduardo Baptista, presidente da Sky Brasil, Carlos Langoni, ex-Banco do Brasil; e Flavio Godinho, executivo no Grupo EBX entraram no poder com o objetivo de modernizar os métodos e as práticas de gestão do clube, e assim, obter a profissionalização no triênio de 2013 a 2015.

O atual Vice Presidente de Futebol do clube, Gerson Biscotto, conta uma experiência vivida por ele, onde podemos observar a diferença de como era antes da gestão atual.

"Em 2003, fui candidato à Presidência do Flamengo, disputei com o Marcio, e no dia da eleição, ele me convidou para ser Vice Presidente de Remo. A princípio não aceitei, pois não conhecia nada de remo, não iria assumir uma coisa que não entendo. Mas o grupo achou interessante que eu assumisse, e quando você não entende, tem que por gente que entende ao seu lado. E eu fui muito feliz, pois coloquei o Ronaldo Carvalho, ao meu lado, medalhista de remo, e fizemos um bom trabalho. Depois, fui para a Vice Presidência de Esportes Olímpicos e em 2005, fui para a Vice Presidência de Futebol. Fiz todo esse histórico, pois hoje o Flamengo é completamente diferente. Hoje, o Flamengo está mais para uma empresa, e acredito que os clubes que não forem nessa linha de profissionalismo, como eu disse, era muito amadorismo, muitos diretores que passavam por lá sem saber o que estavam fazendo. Mas hoje não, hoje o Flamengo tem uma espinha dorsal de executivos aonde não pode voltar como que era. Estamos em uma nova maneira de administrar, e isso é muito importante". (Gerson Biscotto, Vice-Presidente de Futebol)

Uma das primeiras ações de profissionalização do grupo foi contratar um CEO para o clube. Fred Luz foi contratado. Formado em Administração de Empresas na PUC-RIO, e com vasta experiência no setor de varejo, Fred destaca a importância de uma gestão profissional para um clube de futebol:

"Em qualquer atividade econômica, empresarial, e o futebol não deixa de ser uma atividade empresarial, organizacional, você ter uma gestão profissional significa estar em busca dos melhores profissionais para executar aquela função do negócio. No caso do futebol, é o desempenho esportivo, a empatia com a torcida, quer dizer, o desenvolvimento da torcida, os "fãs", que é a grande fonte de recurso do futebol, e de você ir criando uma escola de aprendizado. O profissionalismo diz isso, é uma especialização para determinados assuntos. Quando você fala de uma gestão amadora, você está falando de pessoas que amam aquilo, aquela atividade, mas que não tem a experiência continuada no 
exercício. Um dos maiores custos do aprendizado é o erro, para você aprender, você comete erros. É assim, na medida em que você tem uma filosofia de administração amadora, você tem um rodízio das pessoas sem criar os degraus necessários de aprendizado. Enquanto quando você tem um profissional em qualquer atividade, esse vai se especializando, vai tendo uma exposição aos problemas e assim o aprendizado é continuado. Por isso que é melhor sempre, a longo prazo, você ter um profissional cuidando das tarefas, do que ter um amador em qualquer atividade" (Fred Luz, CEO)

Um fator que poderia atrapalhar essa profissionalização do clube era o modelo associativo do Flamengo, ou seja, uma organização sem fins lucrativos. Dentre as diversas características do associativismo, uma das principais é o trabalho voluntário de seus dirigentes, isso significa que o trabalho é executado com dedicação parcial, de maneira não remunerada e não necessariamente especializada. $O$ artigo 162 do Estatuto do clube confirma isso, "Os membros dos Poderes não poderão ser remunerados". (Estatuto Flamengo, 1992). Entretanto, Fred explica como a modernização da gestão não é prejudicada por esse modelo.

"Na medida em que o clube for construindo o processo da participação dos armadores em um tipo de conselho de administração, que dá os objetivos, as metas, aprova os orçamentos para que o grupo de executivos profissionais entregue, iremos chegar em um modelo que concilia a questão da propriedade, que é a dos sócios, representados por uma diretoria, uma administração escolhida por eles, com uma equipe profissional. $E$ isso que o Flamengo está tentando montar. Na medida em que seja estruturado, o fato de ser uma instituição associativa não prejudica em nada" (Fred Luz, CEO)

\subsubsection{Planejamento Estratégico}

Para Serra (2004) planejamento estratégico é o instrumento que ordena o que se pretende que aconteça. $\mathrm{O}$ autor ainda complementa afirmando que é o processo pelo qual acontecimentos futuros são antecipados, de forma que ações sejam implementadas para atingir os objetivos de uma organização. A elaboração de um planejamento estratégico deve refletir o raciocínio estratégico de uma organização.

Assim como em qualquer organização, um clube de futebol deve realizar o processo de planejamento estratégico. O primeiro passo para isso é a definição da missão e da visão da empresa. O Flamengo não possui esses atributos especificados e Fred Luz explica o por que:

“Nós temos uma visão e uma missão, mas ainda não está devidamente aprovada pela diretoria. Nessa administração tentamos fazer os primeiros passos de um planejamento 
estratégico, o que acabou que não aconteceu. Está nos nossos objetivos a gente fazer essas seções de definição estratégica do Flamengo, aonde você define a missão, a visão, os valores. Para 2016, já estamos criando as condições para isso". (Fred Luz, CEO)

Entretanto, existe outro indicador de direção, que são os objetivos estratégicos. E segundo Fred, o Flamengo define objetivos estratégicos. O planejamento do clube funciona a partir da definição de metas, a partir do conselho diretor e aprovação de orçamento. Vale ressaltar que muitas das decisões são tomadas com a pressão do dia a dia, pois o resultado do time influencia diretamente na aceitação das ações planejadas.

"O clube define sim, esses objetivos são os objetivos do Flamengo, que tem objetivos do futebol profissional, objetivos do futebol de base, objetivos da área de finanças, objetivos da área de marketing, objetivos dos esportes olímpicos, aonde que cada diretor dessas áreas conhece seus objetivos, negociou esses objetivos. O departamento de futebol, você desdobra objetivos que são do técnico, desempenho desportivo; da área de logística, otimização da sistemática de viagens, redução de custos, otimização, conforto para os jogadores. Têm os objetivos das categorias de base, formação de atletas de base, número de atletas de base nas seleções das categorias. Como você tem objetivos financeiros, como o marketing, você tem uma meta de receitas, tem que ter $X$ milhões de receita de patrocínio, $X$ milhões de receita de sócio torcedor, $X$ milhões de receita de bilheteria dos jogos e assim você começa a ver que possui uma interligação entre esses objetivos. Mas hoje, já temos essas metas todas, e estamos no momento de montar essas metas para 2016 e o orçamento". (Fred Luz, CEO)

Dessa forma, percebemos que as áreas de marketing, finanças e futebol devem estar sempre alinhadas. Biscotto afirma que antigamente o departamento de marketing era quase imperceptível no Flamengo, e hoje em dia, está muito mais integrado, pois um departamento depende do outro. Entretanto, Fred diz que esse alinhamento, essa integração é um aspecto em que o clube precisa melhorar bastante ainda. Ele ainda dá um exemplo de como é feita essa integração.

"A pré-temporada. O marketing tem um objetivo de fazer uma receita de bilheteria, 0 futebol tem toda sua estrutura da pré-temporada, mas esse período do ano como não tem jogos de campeonato oficial, estamos usando para fazer alguns amistosos que são extremamente rentáveis para o Flamengo. O clube tem uma característica especial de ser um clube nacional, onde tem torcedor em todos os cantos do país. Assim, tenho uma grande oferta para fazer uma arrecadação de $X$ milhões de reais em 2 jogos em Teresina, 0 que é superior ao que ganho no Campeonato Carioca inteiro, então o Flamengo não pode abrir mão de fazer isso, mas tem que combinar o marketing com o diretor de futebol. $O$ marketing não pode ficar marcando partidas para o time de futebol sem estar alinhado, pois, 
primeiro, tem o objetivo financeiro e o outro tem o objetivo esportivo. Eventualmente, se você vai para gerar receita prejudicando o desempenho esportivo, não vale a pena, então temos que alinhar". (Fred Luz, CEO)

O departamento de Marketing do Flamengo foi completamente reestruturado nessa gestão. Foi encontrado sem qualquer planejamento, nem ao menos um patrocinador master. Além disso, não havia um projeto consistente de licenciamento de produtos e os poucos patrocinadores existentes teriam seus contratos expirados entre fevereiro e abril de 2013 e não seriam renovados. A partir do desafio de mudar a cara do Marketing do Flamengo, foi promovida a montagem de uma equipe coesa, com a contratação de profissionais do mercado.

Foi criado o conceito de "loja oficial do Flamengo", em um processo inédito no clube. Foi feita uma negociação com parte das lojas revendedoras exclusivas de produtos Flamengo, transformando-as em 22 lojas oficiais do clube (não havia nenhuma), que têm descontos para os sócios torcedores e recebem auxílio do clube. Cada uma paga royalties por uso da imagem do Flamengo, se tornando uma importante fonte de arrecadação.

O programa sócio torcedor foi criado em tempo recorde e em menos de um mês de existência já era um dos 10 maiores programas do Brasil. O programa tem o nome de Nação Rubro-Negra e conta com sete categorias: tradição, raça, raça+, amor, amor+, paixão e paixão+, variando o preço mensal de $\mathrm{R} \$ 29,90$ a 199,90, Um ponto positivo desse programa é o cartão ingresso. Com ele o torcedor não precisa retirar o ingresso na bilheteria do estádio. A própria carteirinha de afiliado do programa serve como entrada para o jogo, e é carregada depois da compra online. Entretanto, esse programa ainda tem muito que melhorar. O que falta para o Sócio Torcedor Flamengo tornar-se um programa melhor é que o clube entenda o que de fato a imensa torcida flamenguista enxerga como vantagem, quais oportunidades farão com que ela se afilie. Não se atrelando apenas ao fato de construir uma equipe melhor a partir do investimento do torcedor. Sabendo disso, Fred comenta alguns pontos que o Flamengo está tentando melhorar nesse programa e explica como continuar crescendo com o programa mesmo que o time não vença suas partidas.

"A relação do sócio torcedor com o clube se dá na medida em que ele consiga ter uma relação com o clube próximo de onde ele vive. Então, imagina o cara que mora em Manaus, onde mais de 50\% da população é Flamengo, quase não tem jogo do Flamengo lá. Então, ele vai em um bar, ou algo do tipo para assistir os jogos. Dessa forma, o Flamengo tem que começar a criar uns ambientes do Flamengo em que o cara vá, e ai que eu consiga em uma Tv digital colocar os jogadores se comunicando de alguma forma com esses torcedores. $E$ assim, o cara vai querer ir mais a esse bar do que a um bar comum, pois é um bar onde ele interage com o Flamengo. E assim, para ele ir, ele terá que ser sócio torcedor, e sendo sócio ele tem descontos, mesmo ele não tendo o jogo, ele tem a relação. Porque nem 
sempre se precisa estar ganhando para ter a relação. Agora, quando você não tem uma forma estruturada de ter essa relação, só sobra o jogo, e com isso, o resultado esportivo tem uma interferência direta nesse processo. Então, nossa visão é um clube de descontos, associado a pontos de relacionamento que vão alavancar o sócio torcedor. Estamos criando um instrumento básico de relacionamento que é um cartão pré-pago, que devemos lançar ainda esse ano, para todos os torcedores do Flamengo terem acesso, mesmo não sendo sócio torcedor. Com esse cartão, poderemos estabelecer um programa de milhagem, na medida que a pessoa faz transações com aquele cartão, ele começa a ter um bônus, ele pode até pagar o programa sócio torcedor com esse bônus. E a gente vai começar a montar redes de descontos regionais, em que a pessoa vai com aquele cartão, por exemplo, se for em uma drogaria com aquele cartão, ele terá desconto. Dessa forma, o Flamengo terá parcerias com as entidades comerciais". (Fred Luz, CEO)

Gerson afirma que hoje em dia, o torcedor está mais próximo do clube, muito devido ao sócio torcedor. Entretanto, Fred diz que o clube ainda não tem muitas medidas de monitoramento da satisfação e desejos dos seus torcedores. Apenas algumas pesquisas junto ao sócio torcedor, possuem uma sensibilidade da pesquisa da torcida, e ano passado fizeram uma pesquisa com os sócios do clube (sócio da sede social), que é o fórum de propriedade do grupo e quem elege.

Hoje o clube conta com diversos parceiros estratégicos, dos mais variados segmentos, que também buscam no clube uma forma de promoção já que é um dos maiores clubes do Brasil. Os principais parceiros são: Adidas, Jeep, Caixa (patrocínio máster), Tim, Ambev, Herbalife e Guaravita. Na grande maioria dos casos, são patrocinadores e geram parte da receita para o funcionamento do clube.

Outro ponto importante para o clube é a questão do próprio estádio. Perguntado sobre isso Fred analisou da seguinte forma:

“Então, isso já está no radar e o Flamengo já está entrando numa fase de se capacitar a ter um estádio. Isso poderá ser o próprio Maracanã, pois tem toda a questão do contrato do consórcio do Maracanã que ele não consegue se viabilizar financeiramente, e no nosso entendimento, o Maracanã não se viabiliza sem o Flamengo. E se o Flamengo fizer um outro estádio sem ser o Maracanã, o que irá acontecer com o Maracanã? Então, essa é a discussão. Já temos alguns sites, grupos financeiros interessados em analisar projetos para o Flamengo, para o estádio". (Fred Luz, CEO)

Perguntado se existe alguma ação de internacionalização da marca do clube, Fred afirma que hoje em dia existe mais uma intenção, do que uma realização. Entretanto, o Flamengo possui algumas iniciativas relacionadas ao tema, como, por exemplo, o contrato com a Adidas, onde a empresa é obrigada a distribuir camisas do time em cerca de 1500 
lojas espalhadas pelo mundo. Outra iniciativa foi o convite recebido para uma prétemporada nos EUA, porém ainda não se concretizou. E, também, o clube pretende participar de torneios fora do país nas categorias de base.

Além disso, o Flamengo monitora o que os outros clubes estão fazendo para atingirem melhores resultados. Uma prática realizada por eles foi visitar o Centro de Treinamento de outras entidades, como o Corinthians. Também, contrataram o serviço de uma empresa de consultoria americana chamada "EXOS", para mapear todos os processos do clube em relação ao desempenho esportivo e fazer sugestões e criticas. Essa consultoria já está no Atlético-PR desde o início do ano.

Em relação à CBF, órgão responsável pelo futebol no país, Fred afirmou que o clube monitora as ações da confederação fazendo visitas periodicamente na sede, seja ele ou o Presidente. Entretanto, Gerson disse que hoje em dia, a CBF está uma confusão, como está envolvida em alguns escândalos de corrupção, fazer um acompanhamento fica complicado.

Por último, o clube realiza o controle desses objetivos. Fred comentou que existe um processo estruturado de acompanhamento das metas ainda de 2015, já foram treinados mais de 100 pessoas para o Flamengo, do grupo profissional, para aprenderem a registrar o acompanhamento dos objetivos, somente no futebol mais de 40 pessoas.

\subsubsection{Relacionamento com os jogadores}

Um dos principais fatores para que um clube de futebol tenha resultados favoráveis, se não for o principal fator, é o jogador. Saber montar um bom elenco, liderar, motivar, treinar, manter um bom clima entre o grupo de jogadores não é uma tarefa fácil. Portanto, os clubes que possuem essa capacidade e exercem essas tarefas da melhor maneira possível, saem ganhando.

Primeiro, a comunicação entre os gestores e os jogadores deve ser eficiente. O clube deve passar objetivamente as tarefas a serem cumpridas pelos jogadores. Para Oswaldo de Oliveira, técnico do Flamengo, o clube ainda está evoluindo nesse sentido, está se desenvolvendo em vários setores para que essa troca de informações seja o mais claro possível.

Consequentemente, para que os jogadores possam ser eficazes ao realizar suas tarefas, eles devem saber com que propósito estava fazendo aquilo, ou seja, devem conhecer os objetivos e as metas da organização. Para Fred Luz, os jogadores não precisam saber os objetivos gerais da organização, como, por exemplo, quanto o clube deve lucrar, e sim, as metas e objetivos relacionados a eles. Dessa forma, ele afirma que os 
jogadores possuem metas esportivas, ou seja, ganhar os jogos, bom desempenho nas competições e, também, a melhoria continua.

Oswaldo acredita que de uma forma geral, os atletas conhecem os objetivos e as metas do clube, porém afirma que a rotatividade do elenco dificulta esse conhecimento.

"Ocorre que as mudanças são muito grandes, os elencos são mutáveis, a cada ano, as vezes nem anualmente, semestralmente jogador se vai e vem. Isso se torna esse conhecimento muito limitado. Os que permanecem mais tempo e conseguem transmitir aos companheiros, facilita muito". (Oswaldo de Oliveira, técnico de futebol)

Já Biscotto, tem uma visão diferente sobre o assunto. Para ele, os jogadores desconhecem e afirma que falta responsabilidade dos atletas.

"Infelizmente não (conhecem), e acredito que isso falta. Na verdade, o Flamengo é diferente, a torcida é diferente, a força é diferente e não basta você ser um bom jogador, com qualidade técnica, precisa de um algo mais. Precisa ser mais atleta. Acredito que seja importante que eles conheçam esses objetivos, até pelas responsabilidades, hoje a gente sente essa falta de responsabilidade, são poucos que tem perfil, potencial de ver e enxergar que muitos não tem. E para jogar no Flamengo, não adianta só ser bom de bola, o craque, tem que ter um perfil mais de responsabilidade, de atleta". (Gerson Biscotto, Vice-Presidente de Futebol)

Por outro lado, perguntados se o clube é aberto a receber e reconhecer críticas, opiniões e contribuições de seus jogadores, os três entrevistados responderam que consideram o Flamengo acessível a esse comportamento.

Além disso, um aspecto importante dentro da organização é o clima. Analisando as respostas dos três entrevistados sobre quais fatores mais impactam o clima organizacional, percebe-se opiniões diferentes sobre o assunto. Biscotto afirma que a credibilidade da diretoria é hoje um fator muito importante.

"O Flamengo hoje tem uma moeda hoje muito forte que não existia antigamente. Como, por exemplo, em 2005, quando assumi, tive uma dificuldade absurda de contratar jogadores, pois ninguém queria jogar aqui, uma situação financeira muito ruim. Hoje os jogadores querem vir para o Flamengo, pois o Flamengo tem credibilidade, está pagando em dia, esta pagando suas dividas. Isso para você poder cobrar o profissional, seja atleta ou qualquer profissional você tem que fazer sua parte. Acredito que a credibilidade hoje do clube é um fator muito importante para o clima". (Gerson Biscotto, Vice-Presidente de Futebol)

Fred Luz afirma que a transparência, a honestidade, a sinceridade são fatores fundamentais para o relacionamento saudável entre as pessoas e, assim, um bom clima organizacional. Já, Oswaldo acredita que no Flamengo o que mais impacta o clima 
organizacional é a torcida. Para ele, o que rege o clube é a massa de torcedores que a entidade possui.

O relacionamento entre os dirigentes e os jogadores, na visão do Oswaldo, é excelente. O técnico está no comando do time a cerca de 2 meses e afirma que foi muito bem recebido por todos e está procurando retribuir essa receptividade. Aliás, o treinador também comentou que o relacionamento entre os próprios jogadores é muito bom, um grande indicador disso é que nas concentrações, quando terminam as refeições, permanece um grande número de jogadores conversando, trocando idéias. Ele já trabalhou em diversos clubes e diz que nem todo o clube tem essa prática. Ele pensa que isso é muito importante.

A liderança dentro de um time de futebol é muito importante como em qualquer empresa. No clube é fácil de identificar três diferentes lideres: o gestor, o técnico e um jogador, normalmente o capitão, porém, podendo ter mais de uma liderança dentro de um grupo. Dessa forma foi perguntado aos três entrevistados quais eram as principais características de um líder.

Para Fred Luz, um bom líder deve ter a capacidade de transmitir com clareza os objetivos, sendo também um grande motivador, para tirar o melhor de cada pessoa. Então, o líder deve passar os objetivos, motivar e dar o feedback.

Biscotto compara o líder de antigamente com o da atualidade, onde nos velhos tempos comandava na força, e hoje em dia, é na base da conversa, ajudando e motivando. Além disso, para ele, ser líder é um dom, a pessoa já nasce com essa característica. Oswaldo também acredita que liderança é um dom, mas afirma que podemos desenvolver essa aptidão. Em sua opinião, o líder tem que ser uma pessoa digna que consiga motivar o grupo em uma direção favorável.

Por último, foi pedido que os entrevistados citassem os fatores que, para eles, mais motivam os jogadores e os fatores que mais geram insatisfação desses.

Para Biscotto os fatores que motivam os jogadores são salário em dia, assim como, respeito e condições de trabalho adequadas. E o que gera insatisfação é a falta desses.

Para Fred o que mais motiva uma pessoa é ela perceber que está evoluindo e que está também em um grupo que é vencedor. $\mathrm{E}$ o que faz a pessoa ficar descontente é não estar ganhando e não ser reconhecido como acha que deveria dentro daquele ambiente.

E o Oswaldo acredita que o amor pela profissão, por aquilo que ele faz, o prazer de jogar futebol, de buscar vitorias é a grande motivação. Já o que gera aborrecimento, ele afirma:

"Acredito que tenha várias coisas que geram insatisfação em um jogador. Hoje, no esquema profissional, acredito que quando um árbitro erra injustamente e altera muito em um resultado do jogo, salários atrasados também mexem muito e também as concentrações 
são bem desagradáveis para quem joga 70 vezes por ano, é uma rotina bem desagradável". (Oswaldo de Oliveira, Técnico de futebol)

Todos esses fatores analisados são importantes para fortalecer a cultura organizacional do clube e, assim, melhorando o comportamento organizacional e aumentando a consistência do comportamento.

\subsubsection{Visão dos jogadores}

Além das entrevistas em profundidade, foram obtidas 23 respostas de jogadores do time profissional do Flamengo, através de um questionário que contemplou perguntas relacionadas a tempo como jogador profissional, conhecimento da história e da gestão do clube, conforme resultados apresentados a seguir.

\section{Gráfico 2: Quanto tempo joga profissionalmente?}

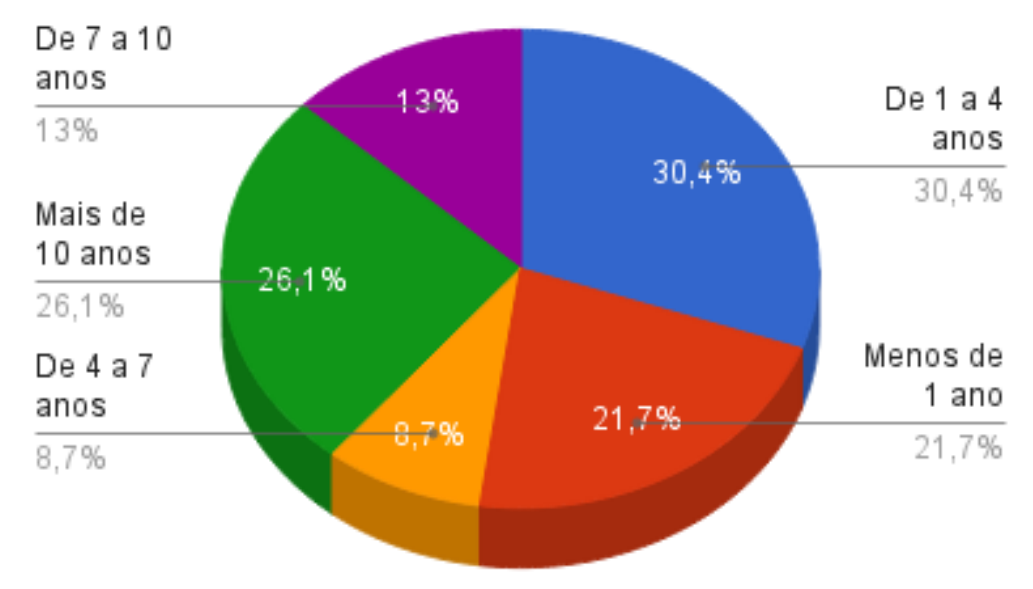

O gráfico acima representa o resultado da primeira pergunta do questionário. Com os 23 respondentes, a pesquisa conseguiu jogadores com bastante experiência, mais de 10 anos $(26,1 \%)$, e aqueles que ainda estão no inicio de suas carreiras , com menos de 1 ano (21,7\%). Portanto, a maioria dos respondentes possui menos de 4 anos de experiência profissional $(52,1 \%)$, porém um número considerável $(26,1 \%)$ possui mais de 10 anos de experiência como jogador profissional. 


\section{Gráfico 3: Quanto tempo joga no Flamengo?}

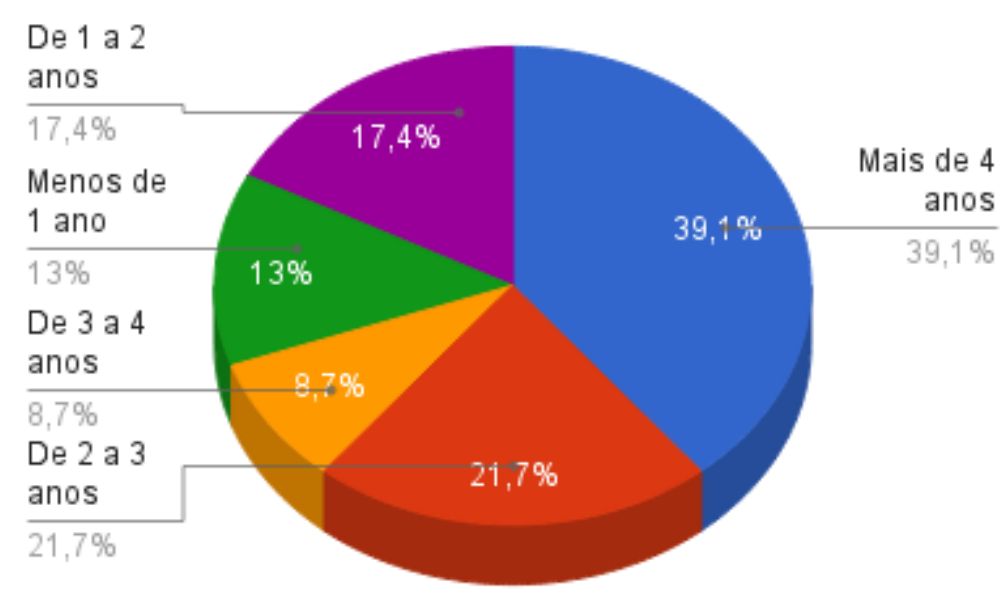

O gráfico acima corresponde à segunda pergunta do questionário, que tinha como objetivo saber a quanto tempo cada jogador já está no clube. Pode-se perceber, que a maioria dos jogadores está há menos de 3 anos no clube $(17,4 \%+13 \%+21,7 \%=52,1 \%)$, ou seja, no Flamengo só possuem a visão desta diretoria. Entretanto, isso também demonstra que eles estavam em outros clubes, e assim, podendo analisar comparativamente a atual gestão do Flamengo com a de outros clubes. Os que estão há mais de 3 anos no clube, contabilizam $47,9 \%$, isso significa que estes jogadores podem fazer uma comparação com antigas gestões do próprio Flamengo.

\section{Gráfico 4: Conhece a história do Flamengo?}

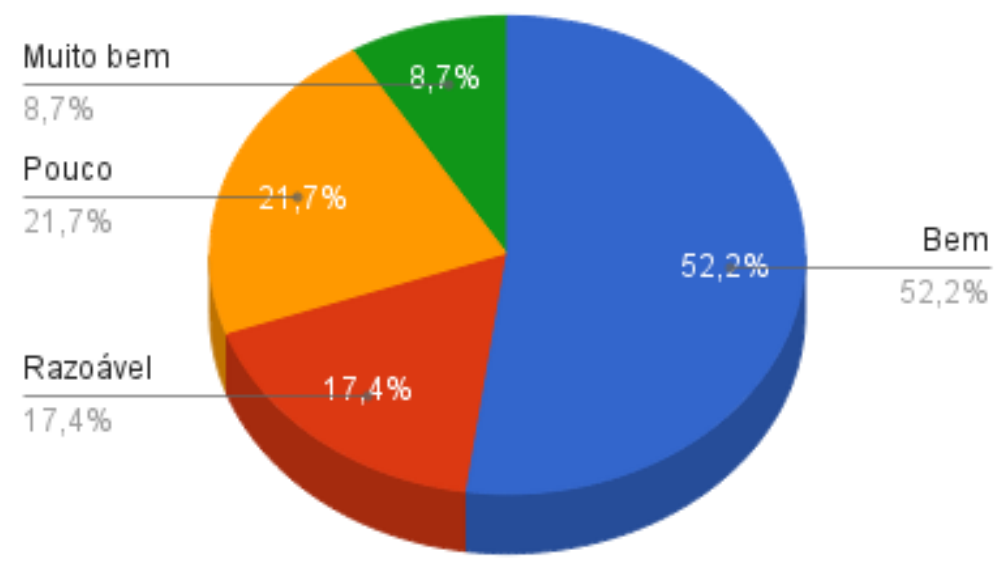

Nessa pergunta, os jogadores deveriam responder se conheciam a história do Flamengo, ou seja, títulos importantes do clube, ídolos do passado do Flamengo, cânticos da torcida. Então, a maioria deles respondeu que conhecia bem a historia do clube $(52,2 \%)$. Nenhum jogador respondeu que conhecia muito pouco da historia do clube. 
O objetivo dessa pergunta foi para servir de parâmetro para a cultura organizacional, pois um bom indicador é saber se os colaboradores conhecem a história, o passado da empresa.

\section{Gráfico 5: Objetivos e metas do Flamengo em 2015}

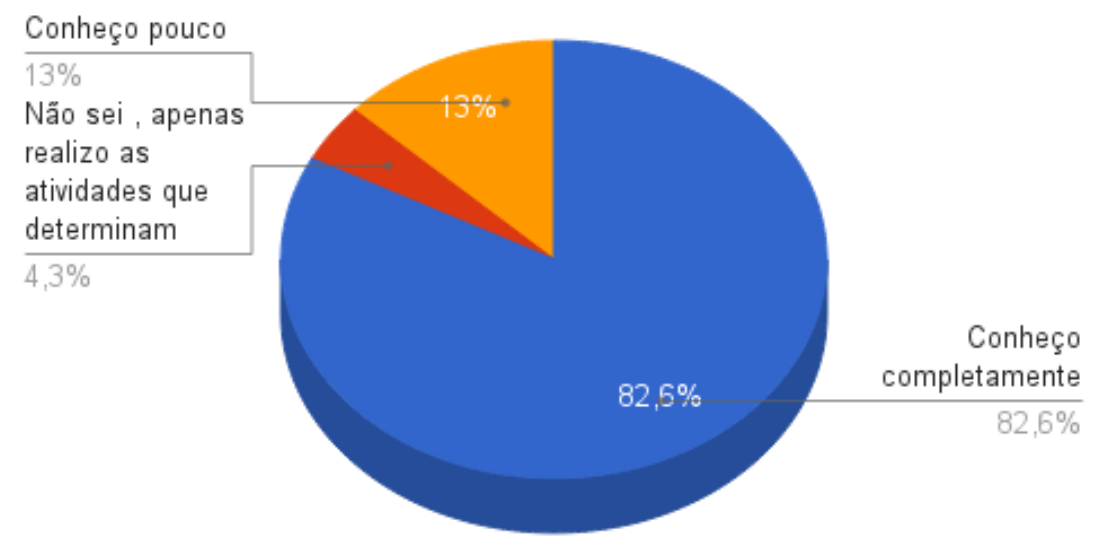

A pergunta do Gráfico 5 se refere à quarta pergunta do questionário. O objetivo dessa pergunta foi saber se os jogadores conheciam os objetivos e as metas do Flamengo em 2015. A grande maioria dos jogadores (82.5\%) respondeu que conhece completamente os objetivos e metas do Flamengo. Vale ressaltar que nenhum jogador respondeu que não se interessa pelas metas do clube.

\section{Gráfico 6: As orientações são claras e objetivas?}

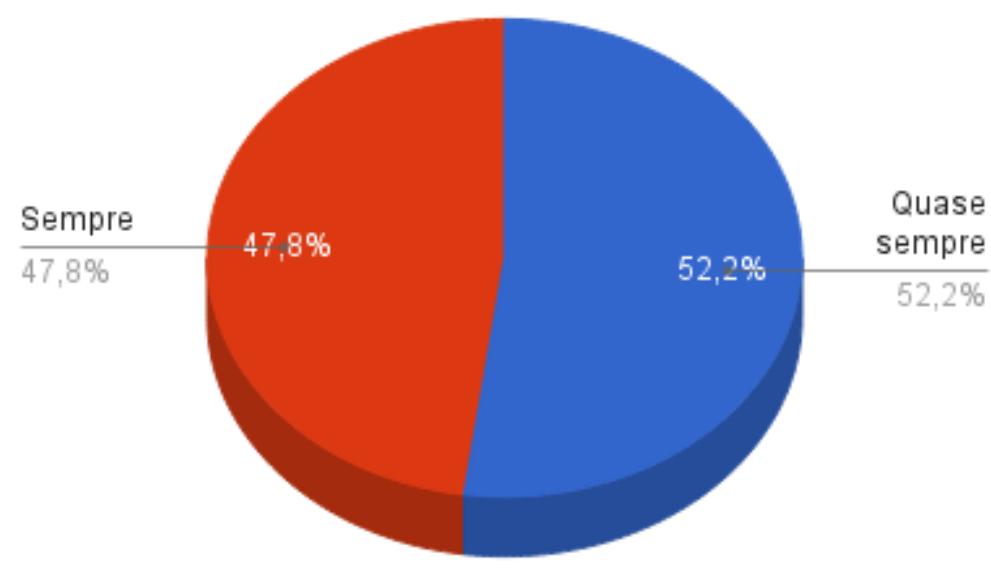

Analisando as respostas no gráfico acima, para a pergunta se as orientações sobre o trabalho são claras e objetivas, percebe-se que ficou dividido em "Sempre" (47.8\%) e "Quase sempre" (52.2\%). Podemos observar que a comunicação, na visão dos jogadores 
está boa, porém pode melhorar. Vale ressaltar que nenhum jogador marcou as opções "Raramente", "Nunca" e "Não tenho opinião".

Gráfico 7: 0 clube é aberto a receber e reconhecer as críticas, opiniões e contribuições de seus jogadores?

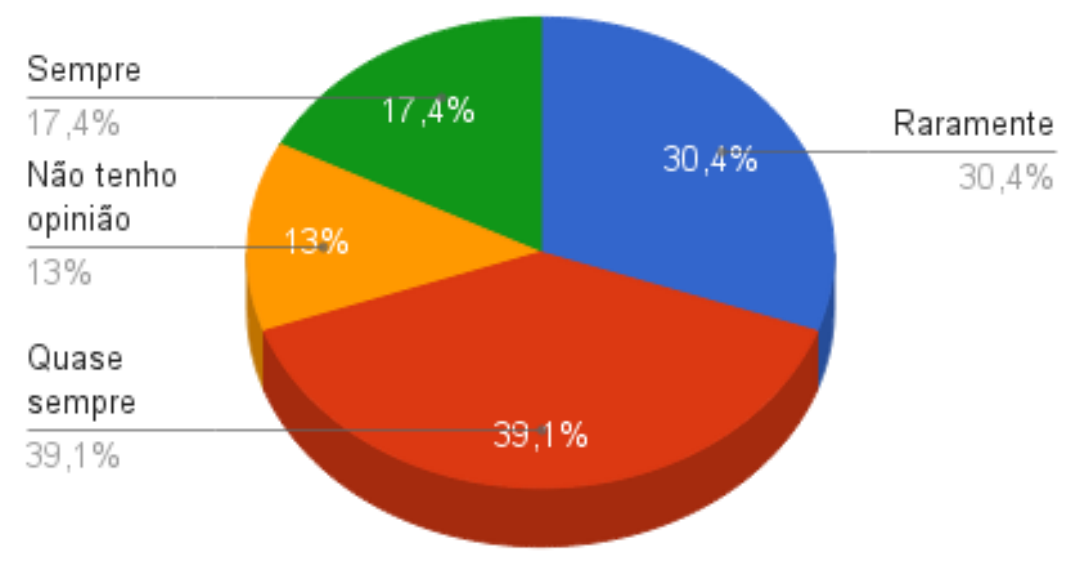

O gráfico 7 se refere à sexta pergunta do questionário. O objetivo dessa pergunta foi saber em relação tanto à comunicação ascendente, de baixo para cima, quanto em relação ao clima e cultura organizacional. Observamos que nenhum jogador respondeu que o clube nunca é aberto para receber e reconhecer as críticas. Entretanto, percebe-se um resultado bastante variado, onde "Quase sempre" $(39,1 \%)$ e "Raramente" $(30,4 \%)$ se sobressaíram. Isso demonstra que o clube pode melhorar nesse aspecto, dando mais espaço para que os jogadores opinem e ajudem no dia a dia, pois são membros de grande importância na organização.

Nesse sentido, a pergunta seguinte, foi feita para saber se os jogadores se sentem responsáveis pelo sucesso da organização, se faz parte do dever deles que a empresa tenha sucesso.

\section{Gráfico 8: 0 jogador tem a responsabilidade de contribuir para o sucesso do clube?}

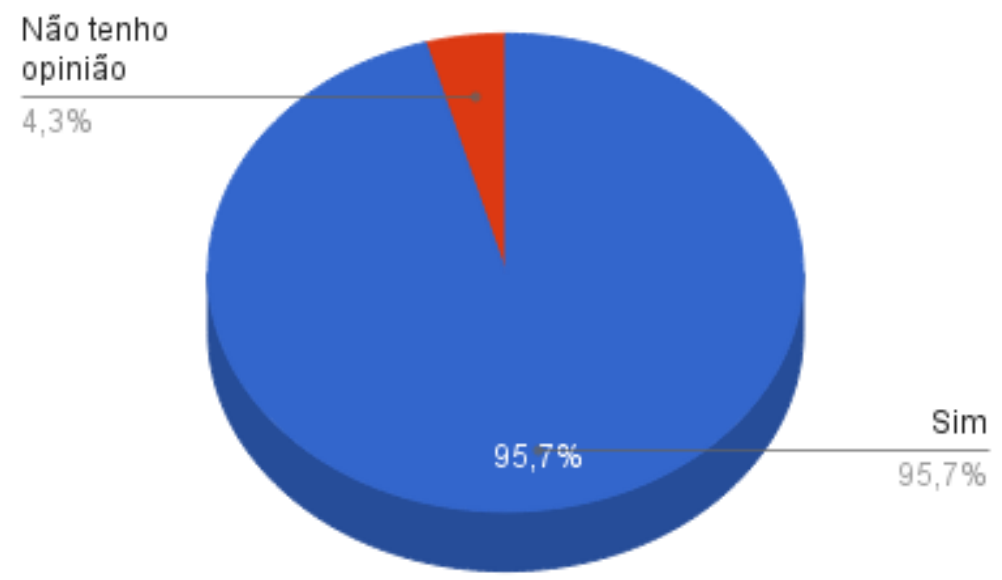


Analisando as respostas, vemos que quase todos os jogadores $(95,7 \%)$ consideram responsabilidade deles em fazer com que o clube tenha êxito. Demonstrando um grande comprometimento com a organização, impactando no clima organizacional.

\section{Gráfico 9: Relacionamento entre os jogadores}

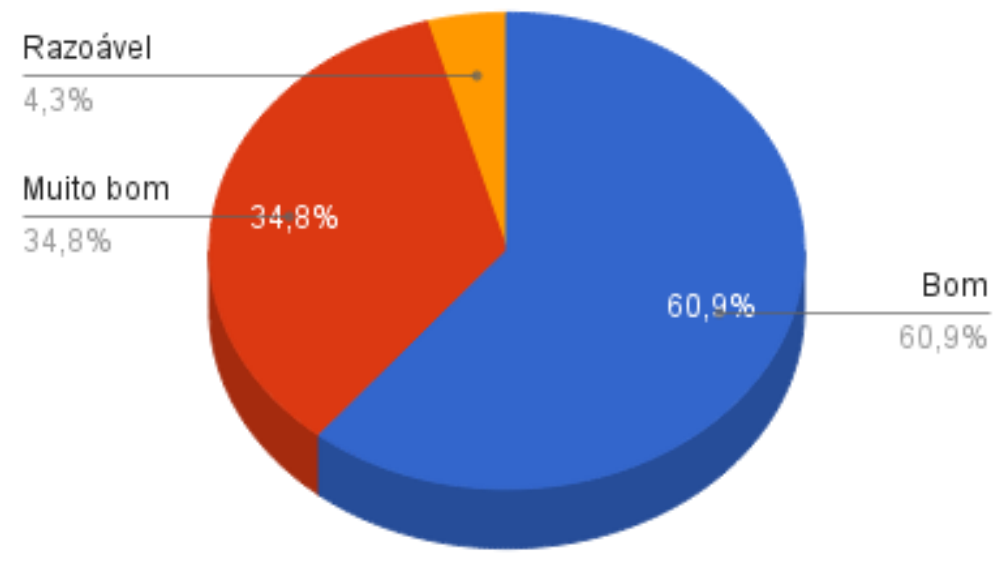

O gráfico acima se refere à oitava pergunta do questionário. $\mathrm{O}$ objetivo dessa pergunta foi saber como os jogadores avaliam o relacionamento interpessoal, a comunicação horizontal. Isso impacta diretamente no clima e na cultura organizacional. Segundo Luz (2001), o clima retrata o grau de satisfação material e emocional das pessoas no trabalho, influencia profundamente a produtividade do empregado Então, pelas respostas, podemos observar que quase todos os jogadores $(95,7 \%)$ consideram "Bom" ou "Muito Bom" o relacionamento entre eles. Assim, proporcionando um clima organizacional positivo.

\section{Gráfico 10: Estilos de liderança}

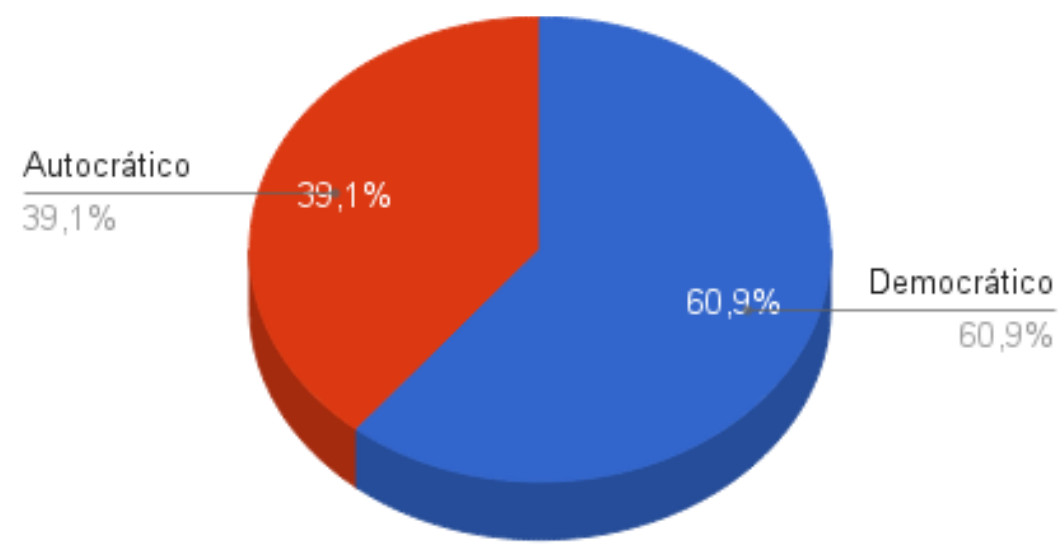


O gráfico 10 se refere à nona pergunta do questionário. Foi perguntado para os jogadores qual estilo de liderança mais agradava, entre "líder autocrático", o líder (técnico / diretor) que determina as tarefas a serem realizadas, exige que sejam feitas como pedido e cobra bastante; "líder liberal", o líder (técnico / diretor) que apresenta os objetivos e deixa com que faça como quiser e não acompanha de perto as tarefas; e "líder democrático", o líder (técnico / diretor) que apresenta os objetivos e deixa que as tarefas sejam realizadas por você, acompanhando e discutindo a melhor maneira de realizá-las, comportando-se como um igual. Curiosamente, nenhum jogador prefere o líder liberal. O líder democrático é o preferido dos jogadores $(60,9 \%)$. Sendo assim, um bom indicador para os líderes reconhecerem as preferências de características dos jogadores, e com essa informação, se adaptar para tornar-se um melhor comandante.

\section{Gráfico 11: Insatisfação Jogadores}

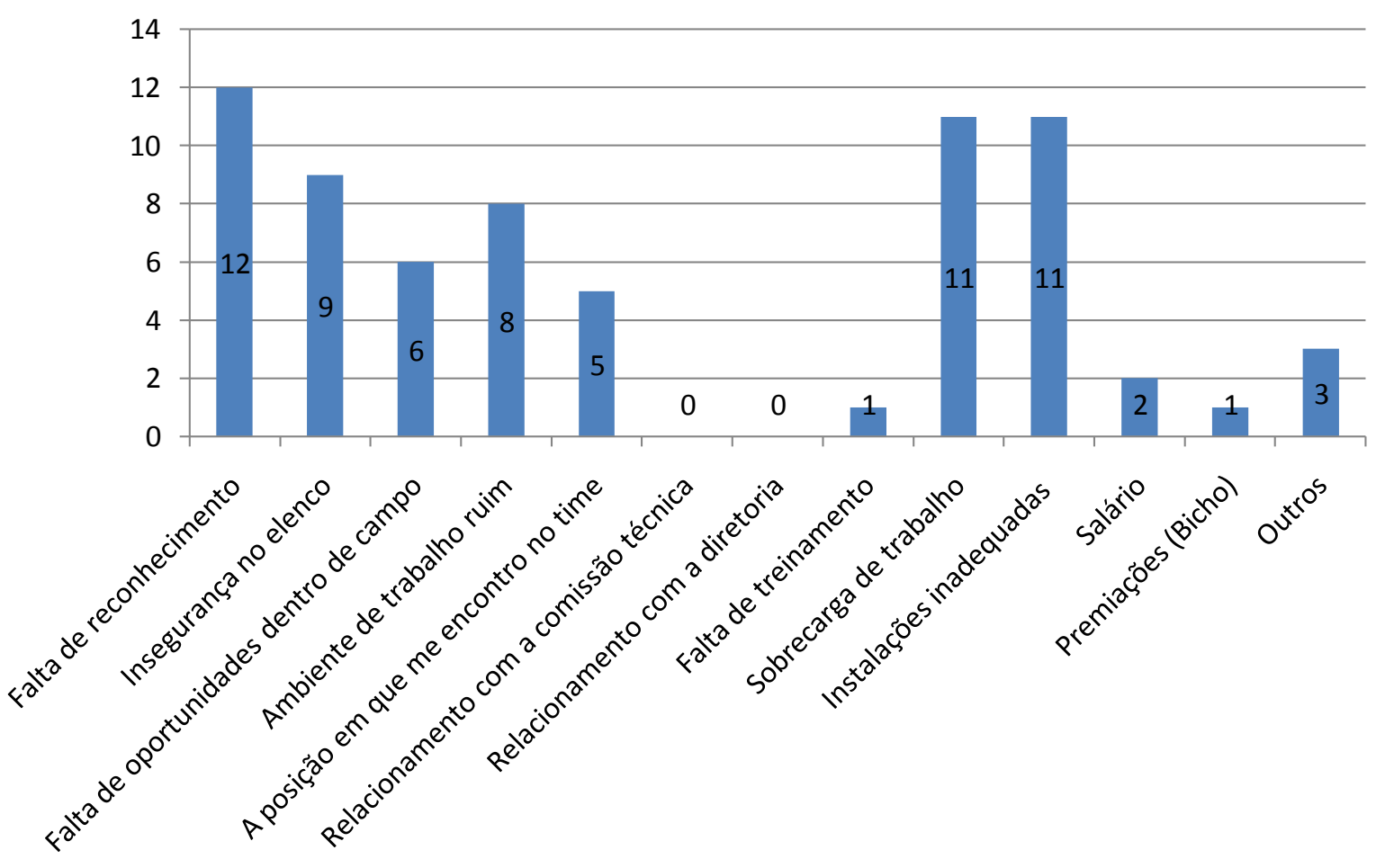

O gráfico acima está relacionado à pergunta 10 do questionário. Nela, cada jogador deveria apontar três fatores que mais geram insatisfação no seu trabalho.

Observando as respostas, podemos analisar o que mais gera insatisfação nos jogadores é a "Falta de reconhecimento", 12 jogadores marcaram como fator de insatisfação. Em seguida, também com um grande número de jogadores marcando, foram 
os fatores "Sobrecarga de trabalho" e "Instalações inadequadas", ambos com 11 atletas. Portanto, com essa pergunta o clube pode perceber o que mais faz um atleta ficar insatisfeito e assim, trabalhar em cima disso.

\section{Gráfico 12: Fatores de motivação dos jogadores}

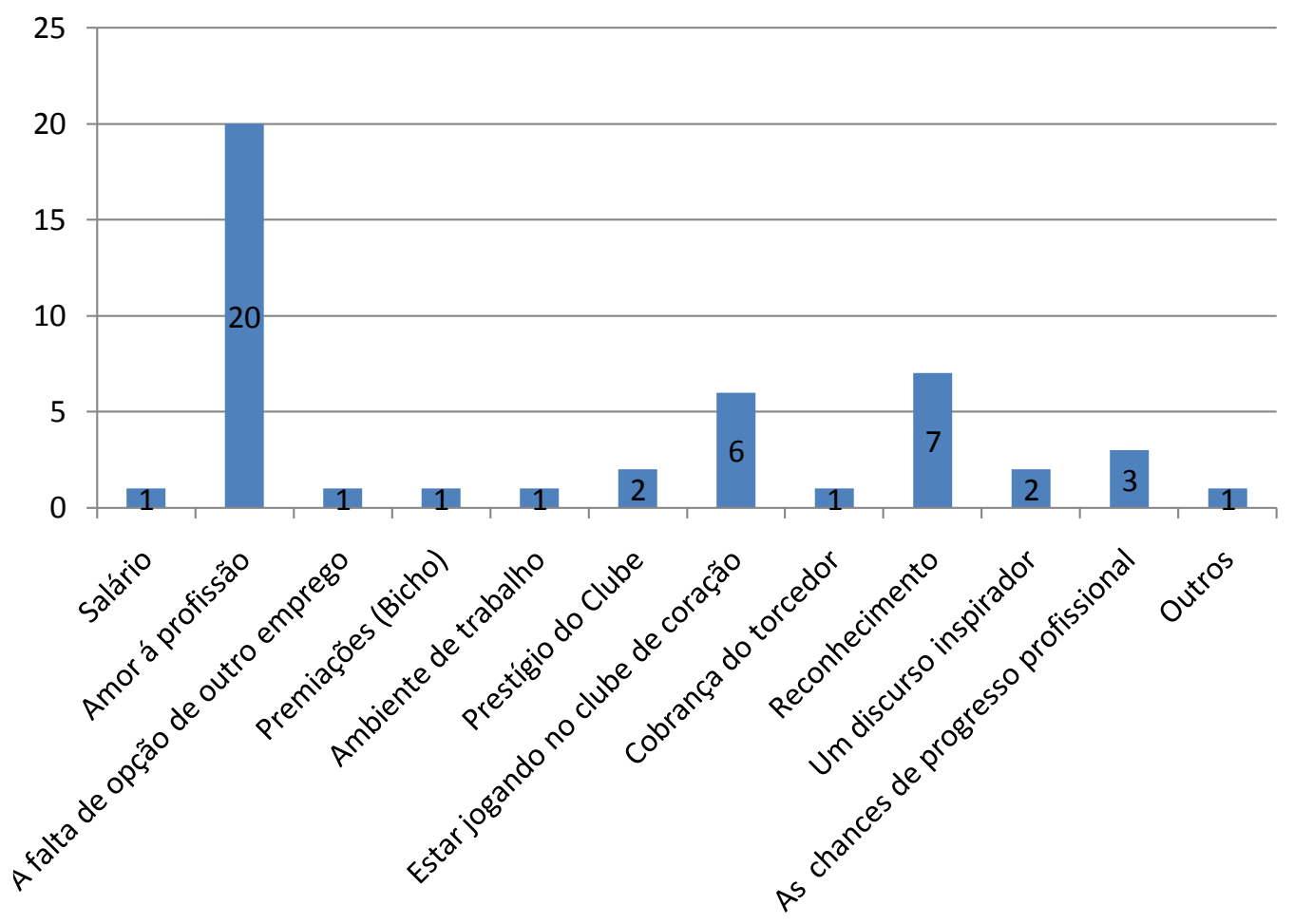

Já na pergunta 11 do questionário, foi perguntado aos jogadores os principais fatores de motivação para entrar em uma partida. Cada jogador devia marcar dois fatores que mais o faziam se sentir motivados.

Podemos observar que quase todos, 20 jogadores, marcaram que o "Amor á profissão" é a maior motivação deles para entrar em campo. Em seguida, os fatores "Estar jogando no clube de coração" e "Reconhecimento", com 6 e 7 jogadores assinalando essas opções, respectivamente. Dessa forma, o clube saberá aonde atuar para que o profissional fique mais estimulado para realizar a atividade.

A próxima pergunta procura saber do jogador se ele se sente realizado praticando esse esporte. Com isso, podemos observar se estão realizados profissionalmente, consequentemente, estão mais motivados e com isso impactando no clima organizacional. 
Gráfico 13: Se sente realizado jogando futebol?

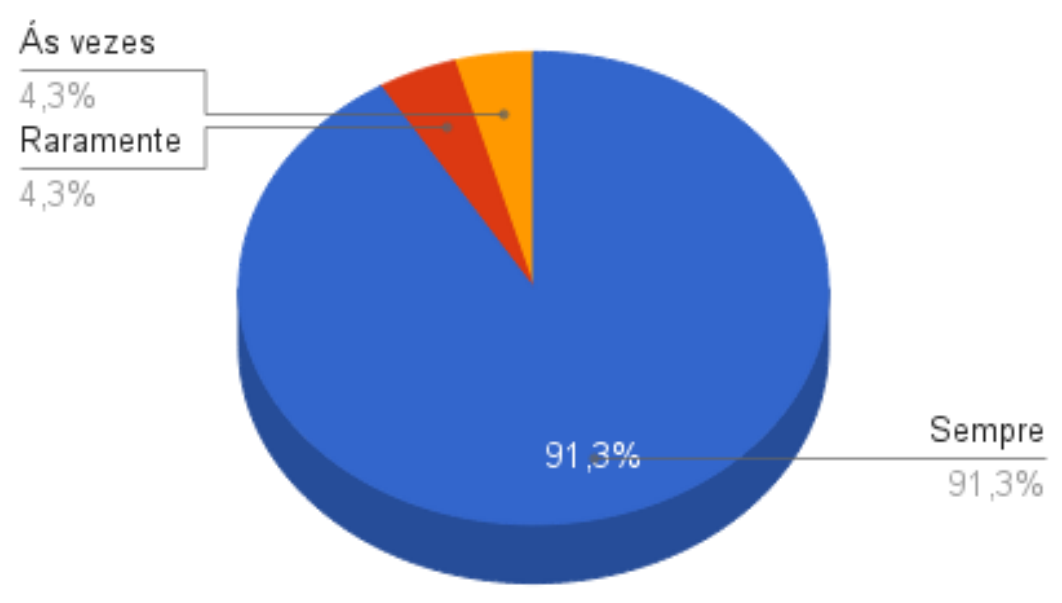

A grande maioria $(91,3 \%)$ está sempre realizada por estar praticando essa atividade, o futebol.

Nesse contexto, de realização com a profissão, a próxima pergunta procurou analisar se o jogador está satisfeito com o seu salário atual. Esse aspecto pode vir a gerar insatisfação do funcionário e, com isso, falta de motivação. Além disso, impactar o clima organizacional.

\section{Gráfico 14: Satisfação com o salário}

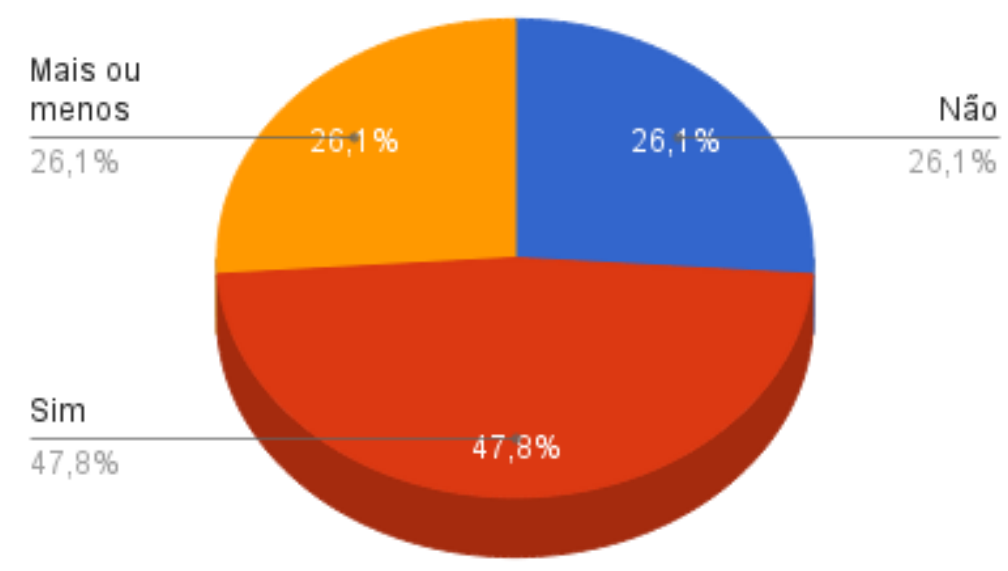

Percebe-se que $47,8 \%$ dos jogadores, ou seja, quase a metade, está satisfeita com o seu salário. $26,1 \%$ não estão nem satisfeitos, nem insatisfeitos com o salário. $E$ os outros $26,1 \%$ não estão satisfeitos com o salário. 
Gráfico 15: O Flamengo é um bom lugar para trabalhar?

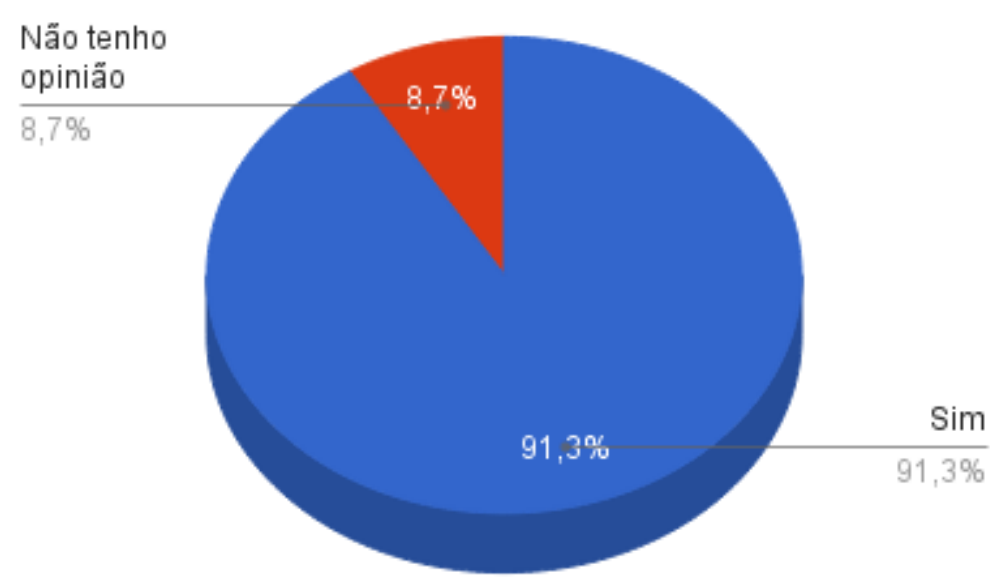

O gráfico acima está relacionado às respostas da questão 14 do questionário. Essa pergunta teve o objetivo de analisar a imagem do clube frente aos jogadores, assim como, o clima organizacional. Percebe-se que a grande maioria $(91,3 \%)$ respondeu que o Flamengo é um bom lugar para se trabalhar.

Já a pergunta seguinte, está relacionada à gestão do clube. Foi pedido para que os jogadores avaliassem a administração do clube, com o objetivo de analisar como os jogadores vêem essa administração, a imagem dela, o clima organizacional e, consequentemente, a cultura organizacional.

\section{Gráfico 16: Avaliação da atual gestão do Flamengo}

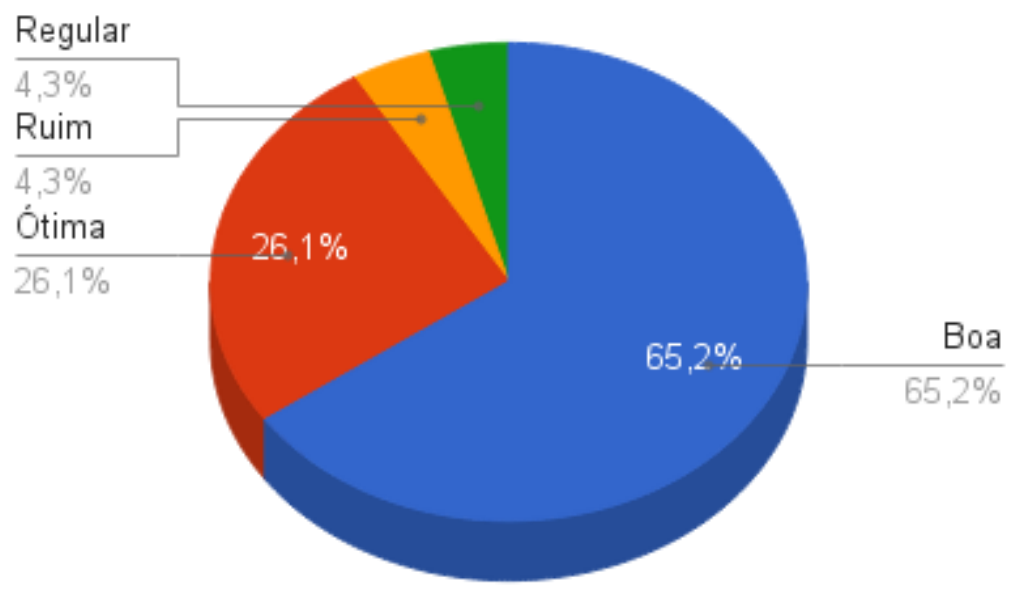


Percebe-se que os jogadores possuem uma boa imagem dessa atual gestão do Flamengo. $65,2 \%$ dos jogadores avaliaram como boa a atual gestão do Flamengo. Apenas $4,3 \%$ avaliaram como ruim e ninguém avaliou como muito ruim.

\subsubsection{Panorama Atual}

A partir dessa renovação da estrutura do clube com o alinhamento de sua gestão, o clube só cresceu e a tendência é que cresça cada vez mais. No início do mandato do Bandeira, no Flamengo, final de 2012, as receitas do clube eram de 212 milhões de Reais, já no final do ano de 2014 cresceram para 347 milhões de Reais, como mostra o gráfico abaixo. Vale ressaltar que ainda não publicaram os resultados desse ano, 2015, último ano

\section{Gráfico 17: Evolução de receitas do Flamengo entre 2009 e 2014 em Reais}

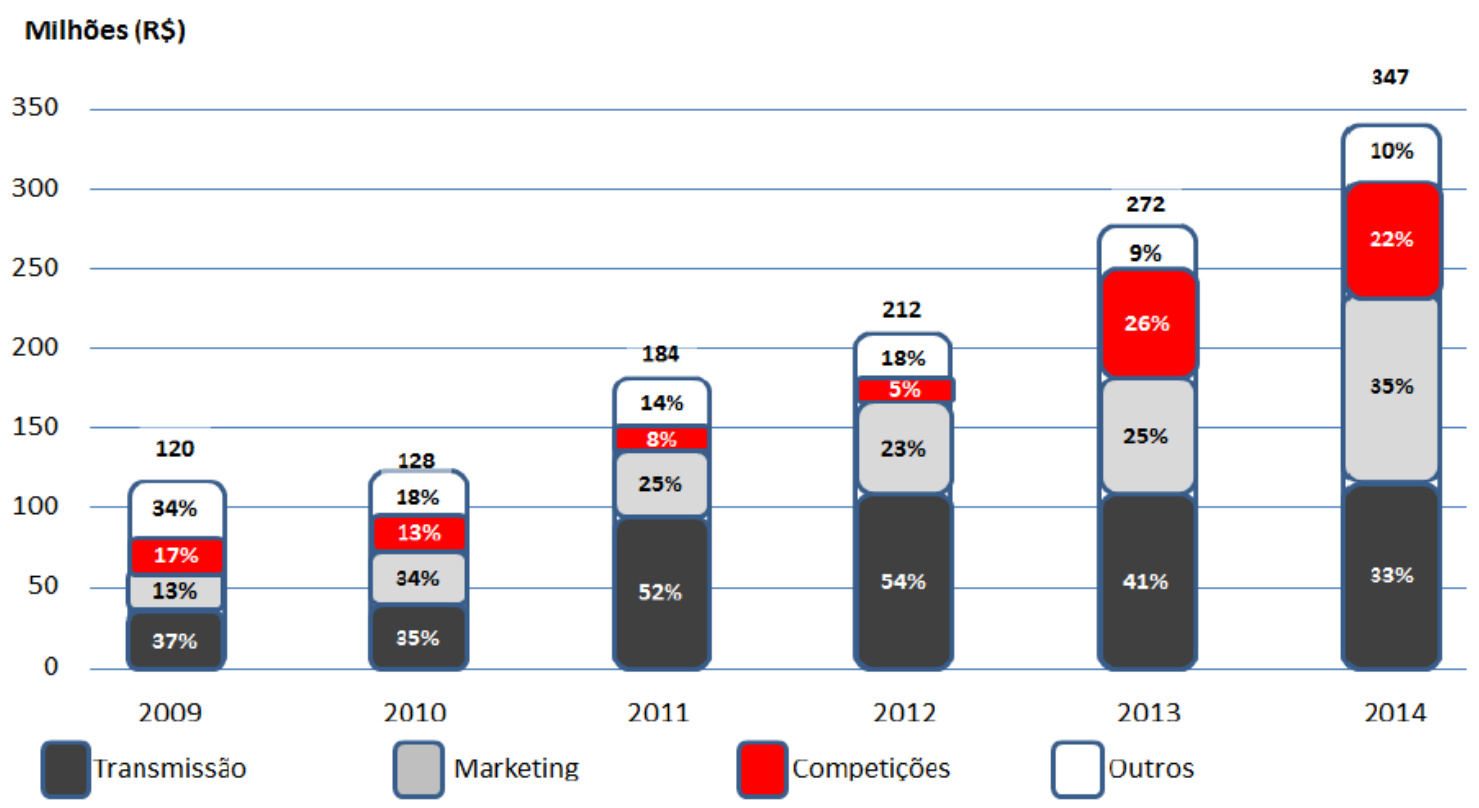

do mandato.

\section{Fonte: Flamego.com.br}

Segundo informação do site Globoesporte.com, o Flamengo é o clube que lidera o ranking de receitas de clubes de futebol no Brasil. Segundo informa a reportagem, o clube está usando o tripé fundamental para o equilíbrio: maximizar receita, controlar gastos e pagar dívidas. Assim, nos últimos quatro anos, o Flamengo foi o único que conseguiu crescer em todos e, além disso, reduzir suas dívidas. (Globoesporte.com, 2015) 
Em relação ao desempenho dentro de campo, o clube ainda não alcançou os objetivos desejados. Nos dois primeiros anos, não possuía um time dos mais competitivos. Porém, esse ano, onde o clube está mais estabilizado financeiramente, já está conseguindo fazer contratações de peso, como, por exemplo, Paolo Guerrero, atacante da seleção peruana. Assim, seguindo esse caminho, o clube espera conseguir vitórias e mais títulos para o Flamengo.

Portanto, como visto na análise acima, pode-se observar a importância de um planejamento estratégico junto com uma gestão profissional para um clube de futebol.

Gráfico 18: As 5 maiores receitas do Brasil em milhões de reais nos últimos 4 anos

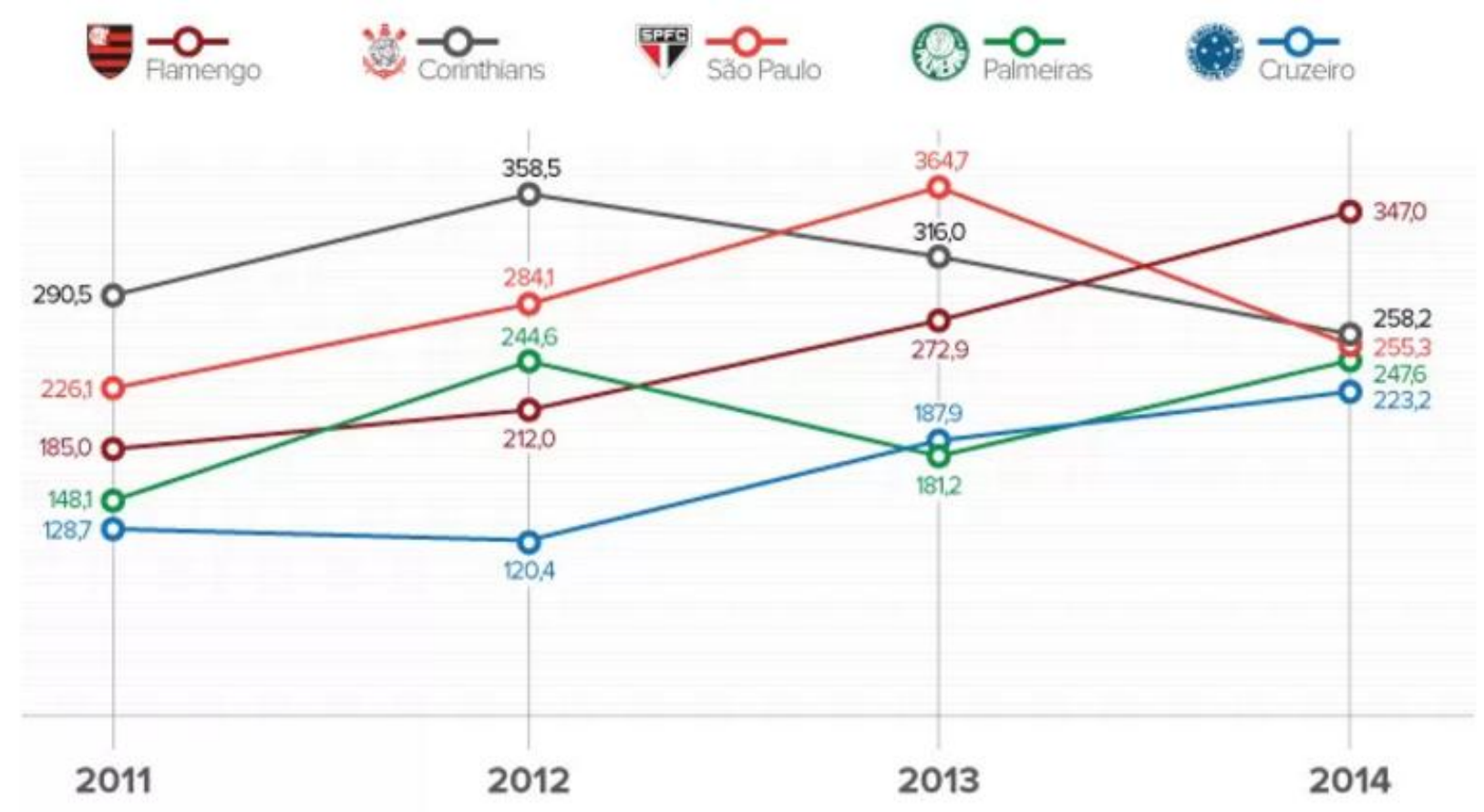

Fonte: Globoesporte.com 
Gráfico 19: As 5 maiores dívidas do Brasil em milhões de reais nos últimos 4

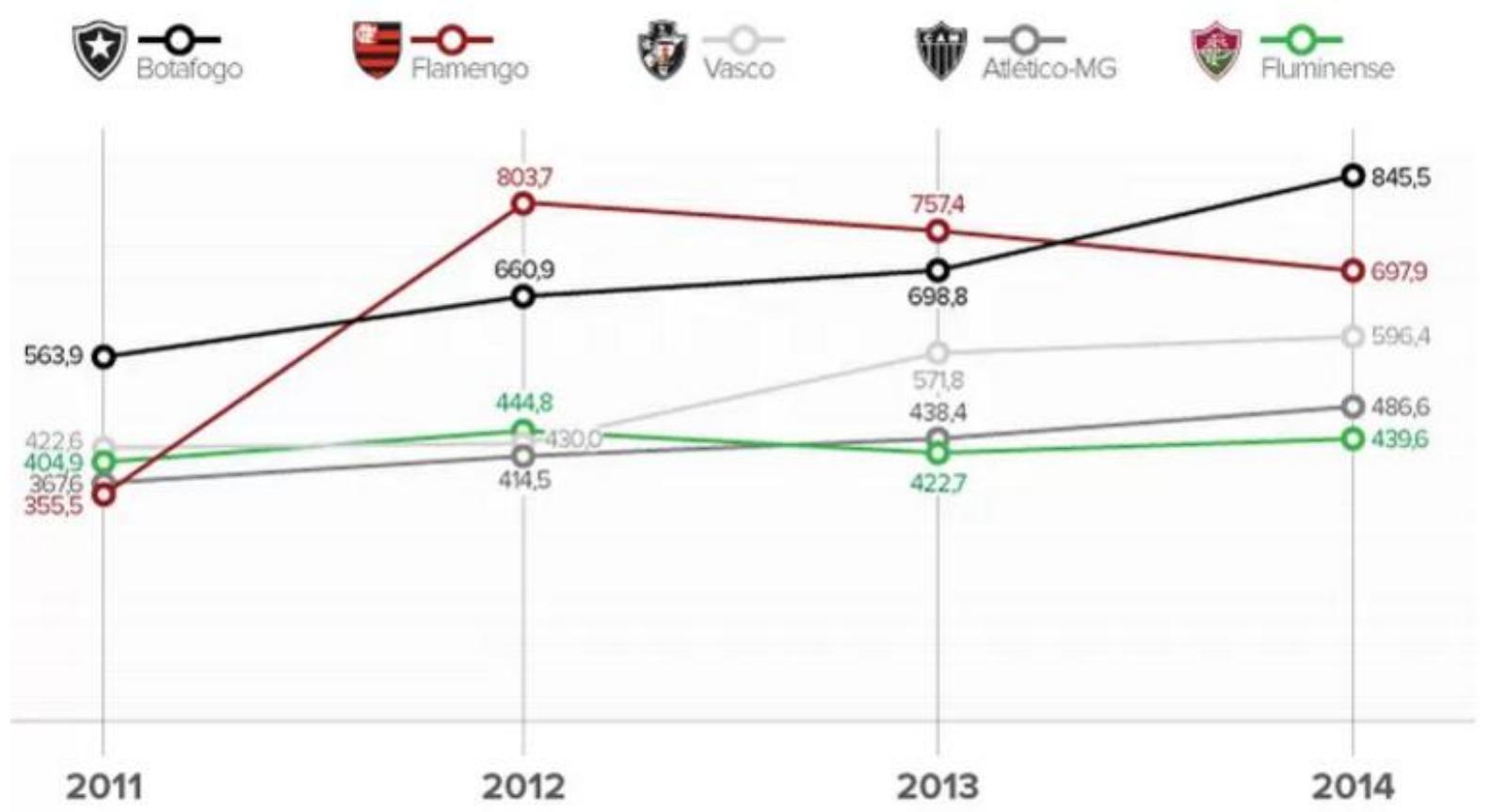

Fonte: Globoesporte.com

\subsection{Comparação entre Real Madrid e Flamengo}

1) Gestão Profissional

O Real Madrid, no ano de 2000, percebeu a necessidade de reestruturar o clube. Dessa forma, no ano consecutivo, o presidente eleito foi o Florentino Perez. Formado em engenharia civil, também atual presidente do grupo ACS (Actividades de Construcción y Servicios), com isso conseguimos notar que ele possui bastante experiência na área de administração. Além disso, ele assumiu o poder no Real Madrid com um discurso de reformar o modelo de comando do clube, tornando a gestão profissional, com novas estratégias e práticas. E assim foi feito e por sinal, bem feito. O clube, primeiro, conseguiu se estabilizar e depois crescer financeiramente.

No Flamengo, a situação foi parecida. Em 2012 o clube estava em uma situação financeira caótica. E então, nas eleições daquele ano, o presidente eleito foi o Eduardo Bandeira de Mello. Formado em administração de empresas, trabalhou mais de 30 anos no BNDES (Banco Nacional de Desenvolvimento Econômico e Social), com isso, percebemos que ele é bastante capacitado para uma função gerencial. Dessa maneira, Eduardo e sua chapa eleitoral assumiram o Flamengo com um discurso de transformar toda a 
administração do clube para uma gestão profissional, algo surpreendente tanto para o clube quanto para todos os clubes brasileiros.

Um fator que representa essa boa gestão é a avaliação que os jogadores fizeram. $65,2 \%$ dos 23 atletas entrevistados consideraram a atual administração boa, enquanto $26,1 \%$ consideram ótima. Portanto, percebe-se que a atual governança do clube possui uma imagem positiva.

Outro fator é o resultado que o Flamengo vem alcançando fora de campo, que é muito bom, reduzindo suas dividas, aumentando suas receitas, e assim, não terminando o ano no vermelho, fato que era bastante comum no clube.

Vale ressaltar a diferença no faturamento entre os dois clubes. Enquanto o Real Madrid obteve de receita 549,5 milhões de Euros, o Flamengo teve 347,4 milhões de Reais. Esse fato se deve pelo tempo em que o Real Madrid já se reestruturou, no final de 2006, e o continuo processo de administração profissional. Já o Flamengo está começando o seu processo, está atrasado cerca de 10 anos. Dessa forma, é importante que haja uma continuidade nessa profissionalização nos próximos mandatos do clube, para que algum dia, quem sabe, chegar a esses valores do Real Madrid.

2) Imagem do jogador

Uma das principais estratégias do Real Madrid foi a contratação de jogadores famosos, como, por exemplo, David Beckham, Ronaldo, Luis Figo, e com isso, além de melhorar a qualidade técnica do seu elenco, explorava comercialmente a imagem do atleta, assim, consequentemente, aumentava o valor da marca do clube.

Hoje em dia, o Flamengo já possui jogadores com certo impacto midiático, como Paolo Guerrero, Emerson Sheik, Paulo Victor. Entretanto, o clube, possuidor dos direitos de imagem dos atletas, não trabalha em cima da exploração da imagem desses jogadores. Seria interessante para o Flamengo isso.

3) Real Madrid como marca global

O Real Madrid teve uma grande preocupação em explorar sua marca além do mercado espanhol. Construiu parcerias internacionais, entrou em mercados emergentes do futebol, como a Índia, conquistando mais fãs, e assim, gerando mais receitas.

Porém, para que isso aconteça, é necessário que o clube possua atletas de qualidade e que, além disso, esteja participando de competições importantes.

O Flamengo, no momento, não apresenta uma preocupação em expandir sua marca para além do mercado brasileiro. 


\section{4) Estádio}

Com um estádio, a arrecadação é maior. Além de receita com bilheteria, o clube tem um ponto de relacionamento com os torcedores e também pode realizar outras atividades comerciais.

O Real Madrid já tinha um estádio, porém realizou uma completa reforma, modernizando suas instalações, com o objetivo de explorar ao máximo comercialmente. Foi uma iniciativa que deu certo e aumentou consideravelmente suas receitas.

Para o Flamengo, a questão do próprio estádio é bem complicada, devido à existência do Maracanã. Entretanto, exemplos como o do Real Madrid ou até mesmo do Palmeiras que conseguem lucrar notavelmente com a exploração da sua arena, é um aspecto a ser levado em conta.

\subsection{Comparação entre a visão dos gestores e jogadores do Flamengo}

Em qualquer empresa, tanto quanto em um clube de futebol, é importante que a mentalidade dos chefes, assim como a dos funcionários, estejam orientadas para a mesma direção. Dessa forma, a comunicação se torna um fator primordial nessa relação.

Analisando os dados, percebe-se que no Flamengo, as orientações sobre as tarefas ainda não são totalmente claras e objetivas. Os gestores e os jogadores confirmam essa informação. Quando metade dos jogadores entrevistados diz que "quase sempre" recebem orientações claras e, também, quando Oswaldo diz que o Flamengo precisa evoluir muito nesse aspecto.

Entretanto, em relação aos objetivos do clube há uma discrepância entre os pensamentos. Os jogadores dizem conhecer completamente, pelo menos aqueles direcionados a eles, ou seja, ganhar os jogos, evoluir, qual a meta para o campeonato, entre outros. Já os gestores, acreditam que não, principalmente quando Gerson diz que isso falta nos jogadores, que esses precisam ser mais atletas, mais responsáveis. Seria interessante que o clube corrigisse essa falha na comunicação.

Outra falha na comunicação está relacionada a recebimento e reconhecimento de criticas, opiniões e contribuições dos jogadores. Enquanto os gestores acreditam que o clube é aberto para receber essas informações, os jogadores analisam de outra maneira, onde "quase sempre" ou "raramente" o clube é aberto. Assim, o clube pode melhorar nesse assunto, dando mais espaço para que os jogadores opinem e ajudem no dia a dia, pois são membros de grande importância na organização. 
O clima organizacional no clube é considerado bom pelos gestores, assim como pelos jogadores, quando a grande maioria considera o Flamengo um bom lugar par se trabalhar. O relacionamento entre os atletas é considerado bom por ambos, do mesmo modo que o relacionamento entre atletas e dirigentes.

O estilo de liderança que mais agrada os jogadores é o democrático. Bem como, os gestores. Quando pedido para relacionar as principais características de um líder, os três citaram traços do mesmo líder escolhido pelos jogadores, o democrático.

As opiniões dos jogadores e dos gestores estão bastante alinhadas a respeito dos fatores que mais geram insatisfação e, também, que mais motivam. Quanto à insatisfação, citaram a falta de condições de trabalho e a falta de conhecimento. Já o que mais cativa esses jogadores a praticarem o esporte é o amor à profissão e o reconhecimento.

Portanto, percebe-se um grande nivelamento entre os pensamentos dos gestores e dos jogadores, o que é bom para a organização. Entretanto, algumas falhas de comunicação devem ser corrigidas para melhorar a integração entre eles. 


\section{Conclusões}

Nos últimos anos o futebol vem aumentando a visibilidade e aumentando seu poderio econômico. São diversas as receitas que o impulsionam transformando-o em negócio. A expectativa de promover ainda mais qualidade ao futebol demonstrou com clareza a ineficiência da gestão praticada atualmente nos clubes.

Dentro desse contexto este trabalho teve como objetivo analisar como uma gestão profissional dos clubes esportivos influencia os resultados de um time de futebol, através de uma análise comparativa entre a gestão consolidada de um clube europeu, Real Madrid CF, e a gestão do CR Flamengo, que inicia o seu processo de profissionalização.

Contribuindo para a análise proposta foram estudadas diversas abordagens conceituais de autores que são referência nesta temática de futebol, dentre eles Mattar, Soriano, Brunoro e Afif. Assim como, também foram abordados os temas planejamento estratégico, cultura organizacional, clima organizacional, comunicação, liderança e motivação.

Brunoro e Afif (1997) destacam a relevância do planejamento estratégico bem elaborado e essa abordagem contribui para a conclusão do presente trabalho, que ressalta como estratégias bem planejadas fazem a diferença no desempenho de um clube.

Para relacionar as informações da pesquisa feita com os dirigentes do Flamengo foi realizado um estudo do caso do Real Madrid a partir de um artigo, de acordo com o ponto de vista de Callejo e Forcadell e também pesquisa com os jogadores do Flamengo.

A metodologia de pesquisa do presente trabalho foi dividida em algumas etapas. Primeiramente, foi realizada uma pesquisa bibliográfica, através da análise de livros, sites, artigos e estudos científicos. Foi realizado um estudo do caso do Real Madrid, entre os anos de 2001 e 2006, de forma que suas estratégias pudessem contribuir para a análise do Flamengo.

Como complemento foram realizadas três entrevistas em profundidade com gestores do Flamengo. Também foi realizada uma pesquisa quantitativa com 23 jogadores do mesmo clube de futebol. A finalização dessa pesquisa foi uma análise cruzada entre: Real Madrid versus Flamengo e dirigentes do Flamengo versus jogadores do clube.

Os resultados mostram que o Flamengo valida a importância de se ter uma gestão ainda mais profissional, com um planejamento estruturado, de longo prazo e um modelo de 
gestão transparente, que privilegie o comprometimento com os resultados e geração de receitas.

Para tal, será necessário que este modelo de gestão iniciado em 2013 se perpetue, fortalecendo ainda mais a cultura organizacional, com ações estruturadas e focadas em um negócio que resulte ganhos para o clube.

Por um lado, uma das possibilidades de ação seria a exploração comercial da imagem dos seus jogadores, prática que o Real Madrid fez muito bem e obteve grandes retornos. Além disso, poderia trabalhar de forma mais efetiva a internacionalização de sua marca, para assim, conquistar mais torcedores e consequentemente, mais receitas. Também, se posicionar em relação a um estádio próprio, grande fonte de recurso e relacionamento com os fãs.

Por outro lado, manter o bom clima organizacional. Percebe-se um grande nivelamento entre os pensamentos dos gestores e dos jogadores, o que é bom para a organização. Entretanto, algumas falhas de comunicação devem ser corrigidas para melhorar a integração entre eles.

\subsection{Sugestões e recomendações para novas pesquisas}

Recomenda-se para estudos futuros o desenvolvimento de pesquisas que investiguem como o papel e a influência dos estilos de liderança dos profissionais, que ocupam posições de alta gestão de um clube, podem influenciar no desempenho e resultados do time.

Novos trabalhos podem ser elaborados contemplando temas como: estilos de liderança, suas práticas e contribuições na gestão e cultura de um clube; na formulação de estratégias; na estrutura e formação de equipes, de forma a impulsionar seus resultados. 


\section{Bibliografia}

ABBEY, A. \& DICKSON, J.W. $\mathbf{R}$ \& $\mathbf{D}$ work climate and innovation in semiconductors. Academy of Management Review, 1983.

BARDIN, L. A análise de conteúdo. Lisboa: Edições 70, 2004.

EXTRA.GLOBO.COM. Em cinco anos, CBF vê seu faturamento crescer $97 \%$, enquanto divida de clubes aumenta 103\%. Jornal Extra, Maio 2015. Disponível em: <http://extra.globo.com/esporte/em-cinco-anos-cbf-ve-seu-faturamento-crescer-97enquanto-divida-dos-clubes-aumenta-103-16310246.html\#ixzz3llj46elO> Acesso em: 01 set. 2015.

BASAGLIA, C.H. A cultura organizacional como estratégia de otimização dos clubes de futebol. $2012 . \quad$ Disponível em: <http://www.comtexto.com.br/convicomcomunicaCarlosBasagliaculturafutebol.html> Acesso em: 20 out. 2015.

BERGAMINI, C.W. Liderança: administração do sentido. São Paulo: Atlas, 1994.

BENNIS, W. A Formação do Líder. São Paulo: Atlas, 1996.

BRUNORO, J; AFIF, A. Futebol 100\% profissional. São Paulo: Gente, 1997.

BITTENCOURT, D. F. Gestão estratégica de pessoas nas organizações públicas: livro didático; design instrucional. Palhoça: UnisulVirtual, 2008.

BOYD; WESTFALL. Pesquisa Mercadológica. Rio de Janeiro: FGV, 1984.

CALLEJO, M.B.; FORCADELL, F. Real Madrid Football Club: A New Model of Business Organization for Sports Clubs in Spain. Global Business and Organizational Excellence, Estados Unidos, volume 26, p.51-64, Nov./ Dez. 2006. 
CARVALHO, A.F. Desenvolvimento do mercado do futebol: um estudo da relação entre gestão profissional e desempenho dos clubes. 2014, 64 f. Dissertação (Graduação de Administração) - Faculdade de Economia, Administração e Contabilidade, Universidade de São Paulo, São Paulo.

CASTELLANI, R.F. A liderança e coesão grupal no futebol profissional: o pesquisador fora do jogo. São Paulo, Setembro 2012. Dísponível em: < http://www.scielo.br/scielo.php?script=sci_arttext\&pid=S1807-55092012000300009>Acesso em: 20 out. 2015.

CHIAVENATO, I. Introdução à Teoria Geral da Administração. Rio de Janeiro: Campus, 2000.

CHIAVENATO, I. Introdução à Teoria Geral da Administração. 7. ed. rev. e atual.- Rio de Janeiro: Elsevier, 2003.

CHIAVENATO, I. SAPIRO, A. Planejamento estratégico. Rio de Janeiro: Elsevier, 2003

COOPER, D.R.; SCHINDLER, P.S. Métodos de Pesquisa em Administração. Porto Alegre: Bookman, 2002.

CORREIA, V. Aprenda a motivar os jogadores com 6 dicas especiais. Setembro 2013. Disponível em: <http://www.teoriadofutebol.com/apps/blog/show/32799422-aprenda-amotivar-os-jogadores-> Acesso em: 20 out. 2015.

DELOITEE. Deloitee Football Money League 2015. Janeiro 2015. Disponível em: <http://www2.deloitte.com/uk/en/pages/sports-business-group/articles/deloitte-footballmoney-league.html> Acesso em: 26 out. 2015.

DRUCKER, Peter F. O homem que inventou a Administração. Rio de Janeiro: Elsevier, 2006.

DRUCKER, P.F. O Melhor de Peter Drucker: obra completa. São Paulo: Nobel, 2002.

FACHADA, M. Psicologia das Relações Interpessoais. Rumo: Lisboa, 2003. 
FERRELL, O.C.; HARTLINE, M.D.; LUCAS, G,H; LUCK, D. Estratégia de Marketing. São Paulo: Atlas, 2000.

GEERTZ, C. A interpretação das Culturas. Rio de Janeiro: LTC, 1989.

GIL, Antonio Carlos. Com Elaborar Projetos de Pesquisa. São Paulo. Editora Atlas S.A., 2002.

GLOBO.COM. Senado instala a CPI do Futebol; Romário é eleito o presidente. Julho 2015. Disponível em: < http://g1.globo.com/politica/noticia/2015/07/senado-instala-cpi-dacbf-romario-e-eleito-presidente-por-aclamacao.html>. Acesso em: 22 ago. 2015.

GLOBOESPORTE.COM. Fla lidera ranking de receitas e é o único dos grandes a reduzir dívida. Maio 2015.2 Disponível em: <http://globoesporte.globo.com/futebol/noticia/2015/05/fla-lidera-ranking-de-receitas-e-eunico-dos-grandes-reduzir-divida-veja-lista.html> Acesso em: 06 nov. 2015.

GUERREIRO, L.E. Como as estratégias utilizadas pelo Barcelona podem ser aplicadas aos clubes brasileiros de futebol. 2014, 57 f. Dissertação - Graduação de Administração de empresas, Puc-Rio, Rio de Janeiro.

HARRISON, J. S. Administração estratégica de recursos e relacionamentos. Porto Alegre: Bookman, 2005.

HERSEY, P., BLANCHARD, K. Psicologia para administradores: a teoria e as técnicas da liderança situacional. São Paulo: E.P.U., 1986.

HOUSE, R. J. A 1976 Theory of Carismatic Leadership. IL: Southern Illinois University, 1977

HUNTER, James C. A review of The World's Most Powerful Principle: How to Become a Servant Leader. Editora Sextante: Rio de Janeiro, 2004.

KAPLAN, Robert; NORTON, David. A estratégia em ação: balancedscorecard. Rio de Janeiro: Campus, 1997.

KFOURI, J. A Gestão de Clubes de Futebol - Regulação, Modernização e Desafios para o Esporte no Brasil. Site UOL, Brasil, Julho de 2012. Disponível em < 
http://blogdojuca.uol.com.br/2012/07/a-gestao-de-clubes-de-futebol-regulacao-

modernizacao-e-desafios-para-o-esporte-no-brasil/> Acesso em: 22 ago. 2015.

KOTLER, J. P. Afinal o que fazem os líderes: a nova face do poder e da estratégia. Rio de Janeiro: Campus, 1999.

LANCENET.COM. Pesquisa Lance e Ibope. Abril de 2015. Disponível em: $<$ http://www.lancenet.com.br/minuto/Pesquisa-LANCE-lbope-FlamengoBrasil_0_1200480135.html>. Acesso em: 06 nov. 2015.

LEWIN, K. Action research and minority problems. Journal of Social Issues, n.2, p.34-36, 1946 Apud FRANCO, M.A.S. Educação e Pesquisa, São Paulo, v.31, n.3,p.483-502, set/dez.2005.

LOWE, K.; GARDNER, W. Ten years of the Leadership Quarterly: contributions andchallenges. Journal of Applied Psychology, 78. 1993.

LUZ, J. N. P. Metodologia para análise de clima organizacional: um estudo de caso para o Banco do Estado de Santa Catarina. Florianópolis, UFSC, 2001

MALHOTRA, N.K. Pesquisa de marketing: uma orientação aplicada. Porto Alegre: Bookman, 2001.

MARANGON, D. Futebol Brasileiro: origens e cultura. 2012. Disponível em: <http:/www.educacional.net/reportagens/futebol/default_imprimir.asp?strTitulo=> Acesso em: 22 ago. 2015.

MATTAR, M.F. Na trave: $O$ que falta para o futebol brasileiro ter uma gestão profissional. Rio de Janeiro: Elsevier, 2014.

MATTOS, R. Dívida dos grandes clubes supera $\mathbf{R} \$ \mathbf{5}$ bi. Maio 2015. Disponível em: $<$ http://rodrigomattos.blogosfera.uol.com.br/2015/05/01/dividas-dos-grandes-clubes-atinge-r5-bi-veja-ranking-dos-debitos/> Acesso em: 06 nov. 2015.

MAXWELL, J.C. A Arte e formar Líderes. Rio de Janeiro: Thomas Nelson Brasil, 2008.

OLIVEIRA, D.P.R. Estratégia Empresarial. São Paulo: Atlas, 1991. 
PLANALTO. Lei № 9.615, de Março de 1998. Disponível em: <http://www.planalto.gov.br/ccivil_03/leis/L9615consol.htm > Acesso em: 08 nov. 2015.

QUEROSERJOGADOR.COM.BR. Como motivar um jogador de futebol. Outubro 2014. Disponível em: <http://queroserjogador.com.br/como-motivar-um-jogador-de-futebol-queroser-jogador/> Acesso em: 20 out. 2015.

REDAÇÃO ABRIL. A cultura do Brasil é o Brasil do futebol. Site Abril, Setembro 2008. Disponível em: <http://www.abril.com.br/noticia/esportes/no_289220.shtml> Acesso em: 22 ago. 2015

ROBBINS, S.P. Fundamentos do comportamento organizacional. São Paulo: Prentice Hall, 2004.

ROBBINS, S.P., JUDGE, T.A., SOBRAL, T. Comportamento organizacional: Teoria e prática no contexto brasileiro. São Paulo: Pearson Prentice Hall, 2010.

RUDIO, F.V. Introdução ao Projeto de Pesquisa Científica. Rio de Janeiro: Vozes, 1986.

RUIZ, J.A. Metodologia Científica. Rio de Janeiro: Atlas, 1991.

SCHEIN,E.H. Organization culture and leadership. San Francisco, JosseyBass, 1986.

SEBRAE. Taxa de sobrevivência das empresas no Brasil. Outubro 2011. Disponível em: <http://www.sebrae.com.br/Sebrae/Portal\%20Sebrae/Anexos/Sobrevivencia_das_empresas _no_Brasil_2011.pdf> Acesso em: 26 out. 2015.

SEIXAS, T. Gestão dos clubes de futebol no Brasil: críticas e reflexões. Agosto de 2011. Disponível em < http://www.efdeportes.com/efd159/gestao-dos-clubes-de-futebol-nobrasil.htm>. Acesso em: 22 ago. 2015.

SEM AUTOR. SITE OFICIAL DO REAL MADRID. Disponível em: < http://www.realmadrid.com/>. Acesso em: 26 out. 2015.

SEM AUTOR. SITE OFICIAL DO FLAMENGO. Disponível em: < http://www.flamengo.com.br/>. Acesso em: 06 out. 2015. 
SEM AUTOR. Estatuto do Clube de Regatas do Flamengo. 1992. Disponível em: < http://www.flamengo.com.br/site/upload/editor/20130425102732_298189.pdf> Acesso em: 06 out. 2015.

SEM AUTOR. SITE OFICIAL DA CBF. Disponível em: < http://www.cbf.com.br/>. Acesso em: 20 out. 2015.

SEM AUTOR. Real Madrid é a equipe mais valiosa do mundo. Site Época negócios, Julho 2014. Disponível em: < http://epocanegocios.globo.com/Informacao/Acao/noticia/2014/07/real-madri-e-equipe-maisvaliosa-do-mundo.html > Acesso em: 26 out. 2015.

SEM AUTOR. BOM SENSO FC. Bom Senso F.C. por um futebol melhor para todos, 2013. Disponível em: < http://www.bomsensofc.org/>. Acesso em: 20 out. 2015.

SERRA, F.A.R.; TORRES, M.C.S.; TORRES, A.P. Administração Estratégica:conceitos, roteiro prático e casos.Rio de Janeiro: Reichmamm\&Affonso Editores, 2004.

SKANK. É uma partida de futebol. Site Vagalume, Brasil, sem data. Disponível em < http://www.vagalume.com.br/skank/e-uma-partida-de-futebol.html > Acesso em 22 ago. 2015.ROBBINS, S.P. Fundamentos do comportamento organizacional. São Paulo: Prentice Hall, 2004.

SOBRAL, F.; PECI, A. Administração: Teoria e prática no contexto Brasileiro. São Paulo: Pearson Prentice Hall, 2008

SORIANO, F. A bola não entra por acaso. Lafonte, 2010.

STONER, James A. O Que é Estratégia? 1985. Disponível em: acesso em 21 de setembro de2015.

THIOLLENT, Michel. Metodologia da pesquisa-ação. 4ed. São Paulço: Cortez Autores associados, 1988.

YIN, R. Estudo de Caso - Planejamento e Métodos. Porto Alegre: Bookman, 2001. P.32 e 35. YIN, Robert K. - Case Study Research - Design and Methods. SagePublications Inc.=, USA, 1989. 


\section{Apêndices}

\subsection{Roteiro de Entrevista com Gestores do Flamengo}

A pesquisa abaixo faz parte do trabalho de conclusão do curso de Administração da Pontifícia Universidade Católica do Rio de Janeiro.

1. Perfil do entrevistado

2. Qual a importância de uma gestão profissional para um time de futebol? Como impacta o desempenho dentro de campo?

3. Você acredita que o modelo do clube, associativo, prejudica ou beneficia uma gestão profissional?

4. Qual é a "Missão e a Visão" do CR Flamengo?

5. O clube define objetivos estratégicos? Quais são os critérios para se definir?

6. Como são medidas as estratégias, como sabem que deram resultado?

7. Você acredita que todos os jogadores conhecem os objetivos e metas do Clube?

8. Há algum planejamento para o Flamengo ter o seu próprio estádio?

9. O clube possui alguma ação de internacionalização da marca?

10. Como é feita a comunicação e o alinhamento estratégico entre os departamentos de Futebol, Marketing e Finanças

11. Como o clube se comunica com os jogadores?

12. O clube passa claramente e objetivamente as tarefas a serem cumpridas pelos jogadores?

13. O clube possui parceiros? Quais os principais? Como funciona a parceria? (Quais os benefícios gerados para o clube e para o parceiro)?

14. O Clube monitora o que os outros clubes estão fazendo para atingir melhores resultados?De que maneira?

15. De que maneira o Clube monitora as ações da CBF?

16. Como o clube monitora a satisfação e os desejos de seus torcedores?

17. Como funciona o programa de sócio torcedor? O que fazer para continuar vendendo mesmo se o time não obtiver bons resultados em campo?

18. Como você considera o relacionamento entre os jogadores? E entre jogadores e dirigentes/gestores?

19. Quais os principais fatores que impactam no clima organizacional do clube? 
20. Você considera o clube aberto a receber e reconhecer as críticas, opiniões e contribuições de seus jogadores?

21. Quais são as principais características de um líder no seu ponto de vista (gestor, técnico ou jogador)

22. Qual(is) fator(es) mais motiva(m) um jogador?

23. Quais as principais insatisfações dos jogadores?

\subsection{Questionário para Jogadores}

1- Há quanto tempo você joga profissionalmente?

( )Menos de 1 ano( )De 1 a 4 anos( )De 4 a 7 anos( )De 7 a 10 anos( )Mais de 10 anos

2- Há quanto tempo você joga no Flamengo?

( )Menos de 1 ano( )De 1 a 2 anos( )De 2 a 3 anos( )De 3 a 4 anos( )Mais de 4 anos

3- Você conhece a história do C.R. Flamengo (títulos importantes, principais jogadores, músicas da torcida, etc.)?

( ) Muito pouco ( )Pouco ( ) Razoável ( ) Bem ( ) Muito bem

4- $\quad$ Com relação aos objetivos e às metas do Flamengo no ano de 2015:

( ) Conheço completamente os objetivos e as metas do Flamengo

( ) Conheço pouco dos objetivos e das metas do Flamengo

( ) Não sei os objetivos e as metas do Flamengo, apenas realizo as atividades que me determinam

( ) Não me importo com os objetivos e metas do clube, somente o que se refere a mim.

5- $\quad$ As orientações que você recebe sobre o seu trabalho são claras e objetivas?

( ) Sempre ( ) Quase sempre ( ) Raramente ( ) Nunca ( ) Não tenho opinião

6- $\quad$ O clube é aberto a receber e reconhecer as críticas, opiniões e contribuições de seus jogadores?

( ) Sempre ( ) Quase sempre ( ) Raramente ( ) Nunca ( ) Não tenho opinião 
7- Você considera que é sua responsabilidade contribuir para o sucesso do clube?

( ) Sim ( ) Não ( ) Não tenho opinião

8- Como você considera o relacionamento entre os jogadores do clube?

( ) Muito bom ( ) Bom ( ) Razoável ( ) Ruim ( ) Muito Ruim

9- Qual o estilo de liderança que mais te agrada?

( ) O líder (técnico / diretor) que determina as tarefas a serem realizadas, exige que sejam feitas como pedido e cobra bastante

( ) O líder (técnico / diretor) que apresenta os objetivos e deixa com que você faça como quiser e não acompanha de perto suas tarefas.

( ) O líder (técnico / diretor) que apresenta os objetivos e deixa que as tarefas sejam realizadas por você, acompanhando e discutindo a melhor maneira de realizá-las, comportando-se como um igual.

10- Indique três principais fatores que geram mais insatisfação no seu trabalho.

( ) Falta de reconhecimento

( ) Insegurança no elenco

( ) Falta de oportunidades dentro de campo

( ) Ambiente de trabalho ruim

( ) A posição em que me encontro no time

( ) Relacionamento com a comissão técnica

( ) Relacionamento com a diretoria

( ) Falta de treinamento

( ) Sobrecarga de trabalho

( ) Instalações inadequadas (banheiros, vestiários, academia, campos etc.)

( ) Salário

( ) Premiações (Bicho)

( ) Outros:

11- Indique as duas principais razões pelas quais você se sente mais motivado para entrar em campo.

( ) Salário

( ) Amor á profissão 
( ) A falta de opção de outro emprego

( ) Premiações (Bicho)

( ) Ambiente de trabalho

( ) Prestígio do Clube

( ) Estar jogando no clube de coração

( ) Cobrança do torcedor

( ) Reconhecimento

( ) Um discurso inspirador

( ) As chances de progresso profissional (contratos melhores, seleção)

12- Você se sente realizado jogando futebol profissionalmente?

( ) Sempre ( ) Quase sempre ( ) Ás vezes ( ) Raramente ( ) Nunca

13- Você está satisfeito com o seu salário atual?

( ) Sim ( ) Não ( ) Mais ou menos

14- Considera o Flamengo um bom lugar para trabalhar?

( ) Sim ( ) Não ( ) Não tenho opinião

15- Em geral, como você avalia a atual Gestão do Flamengo?

( ) Excelente ( ) Ótima ( ) Boa ( )Regular ( ) Ruim ( )Péssima

\subsection{Transcrições das Entrevistas}

\section{Entrevista Gerson Biscotto}

- Qual a importância de uma gestão profissional para um time de futebol? Como impacta o desempenho dentro de campo?

"O resultado está claro, estou no Flamengo direto ou indiretamente a 20 anos. Comecei como diretor do futsal, depois fui para a base, fiquei 11,12 anos. Em 2003, fui candidato a Presidência do Flamengo, disputei com o Marcio, e no dia da eleição, ele me convidou para ser Vice Presidente de Remo, a principio não aceitei, pois não conhecia nada de remo, não iria assumir uma coisa que não entendo. Mas o grupo achou interessante que 
eu assumisse, e quando você não entende, tem que por gente que entende do seu lado. E eu fui muito feliz, pois coloquei o Ronaldo Carvalho, ao meu lado, medalhista de remo, e fizemos um bom trabalho. Depois, fui para a Vice Presidência de Esportes Olímpicos e em 2005, fui para a Vice Presidência de Futebol. Fiz todo esse histórico, pois hoje o Flamengo é completamente diferente. Hoje, o Flamengo está mais para uma empresa, e acredito que os clubes que não forem nessa linha de profissionalismo, como eu disse, era muito amadorismo, muitos diretores que passavam por lá sem saber o que estavam fazendo. Mas hoje não, hoje o Flamengo tem uma espinha dorsal de executivos aonde não pode voltar como que era. Estamos em uma nova maneira de administrar, e isso é muito importante.

- Você acredita que o modelo do clube, associativo, prejudica ou beneficia uma gestão profissional?

"Hoje em dia já caminhamos muito, porque antes o futebol era muito ligado ao clube, a Gávea. E hoje isso já saiu, está em Vargem Grande. Isso tem dois aspectos, primeiro desligar o social do futebol, e isso está acontecendo. Alem disso, o Flamengo tem muitas modalidades, nenhum clube do mundo tem tantas modalidades olímpicas. E pela localização do Flamengo na Zona Sul do Rio, ir separando um ao outro. Acredito que ainda deva fazer outra coisa, a receita do futebol ir para apenas o futebol, e a do clube ir apenas para o clube, como temos exemplos ali do Caiçaras, ser independente. Acredito que não prejudica não".

- O clube define objetivos estratégicos?

"O Flamengo tem um trabalho agora de você conscientizar o profissional, desde o chefe de cada setor e ir passando por todos, com objetivos e metas para cada um. Isso já se iniciou, e acredito que é muito importante. Para cada área, o chefe terá metas até o funcionário mais baixo que seja terá metas. E acredito que seja um progresso muito grande".

- Você acredita que todos os jogadores conhecem os objetivos e metas do Clube?

"Infelizmente não, e acredito que isso falta. Na verdade, o Flamengo é diferente, a torcida é diferente, a força é diferente e não basta você ser um bom jogador, com qualidade técnica, precisa de um algo mais. Precisa ser mais atleta. Acredito que seja importante que eles conheçam esses objetivos, até pelas responsabilidades, hoje a gente sente essa falta de responsabilidade, são poucos que tem perfil, potencial de ver e enxergar que muitos não tem. E para jogar no Flamengo, não adianta só ser bom de bola, o craque, tem que ter um perfil mais de responsabilidade, de atleta. 
- Há algum planejamento para o Flamengo ter seu próprio estádio?

"Estamos pertos em dois sentidos. Primeiro, o próprio Maracanã, o qual eu acho mais viável, mas existe outro projeto, com dois locais de projetos, com parcerias. Então, acredito que seja possível.

- O clube possui alguma ação de internacionalização da marca?

"Contratamos um consultor da empresa Exos, empresa de consultoria em performance. Essa empresa está na seleçao Alemã, seleção Americana. Ele ve tudo que a gente está fazendo, todos os nossos processos para melhorar e organizar. O Flamengo está evoluindo nesse entendimento e é um grande investimento. Ele ja mapeou tudo e ja fez criticas e sugestoes. E isso se nos conseguirmos será um grande avanço".

- Como é feita o alinhamento estratégico e a comunicação entre os departamentos de Marketing, Finanças e Futebol?

"Hoje nós temos vários comitês, pois temos as nossas reuniões de diretoria e as vezes, você perdia muito tempo em determinado assunto e a outra pasta de outra diretoria as vezes não tinha tempo. Foi dividido em vários comitês, desde o diretor daquela pasta com as pessoas que trabalham. Então, hoje o Futebol e o Marketing estão se alinhando, e é uma coisa que já evoluiu muito. Por exemplo, hoje em dia eu também sou Vice Presidente de Remo, e cada 15 dias, as quartas feiras nós nos reunimos, o marketing, os executivos da área para discutir. Então, essa integração tem melhorado muito. E o Marketing que a muitos anos aqui no Flamengo quase não se ouvia falar, hoje em dia está muito mais integrado ao futebol, pois um depende do outro".

- O Flamengo monitora o que os outros clubes estão fazendo para atingir melhores resultados? De que maneira?

"Sim, por exemplo, esse programa da Exos, já está no Atletico PR, eles mantêm três executivos em full-time lá. Estive agora no CT do Corinthians. E isso não é só no Flamengo, em qualquer empresa você tem que estar de olho no concorrente, se você não acompanhar, você vai ficando para trás.

- De que maneira o clube monitora as ações da CBF?

"Sinceramente não sei, pois hoje em está complicado. A CBF está uma bagunça, com vários escândalos e então não tem muito acompanhamento. Infelizmente, eles fazem o que querem e não tem muito o que o clube fazer não". 
- Como o clube monitora a satisfação e os desejos de seus torcedores/ clientes?

"Hoje está mais próximo, muito por causa do sócio torcedor. Acredito que o Flamengo está tentando da melhor maneira possível, através de mais contato, o que antigamente não existia e que hoje tem mais. Já é uma maneira de se aproximar e monitorar".

- Como você considera o relacionamento entre os jogadores?

"Isso é um pouco difícil de analisar, pois nem sempre o que você acha que é, é a realidade. A aparência é uma, mais no fundo não é bem assim. Hoje, apesar de ter alguns acidentes, acredito que os jogadores estao mais bem orientados pelos seus empresários. Mas acredito que ainda precisam melhor um pouco, serem mais profissionais. Entretanto, fazer essa analise é complicado, pois nem sempre o que parece é a realidade.

- E o relacionamento entre dirigente e jogador?

"Acredito que vá pelo mesmo caminho. Um atua de uma maneiro, eu atuo de outra. Você nunca sabe se está agradando ou não, então é difícil analisar".

- Quais os principais fatores que impactam o clima organizacional do clube?

"O Flamengo hoje possui uma moeda hoje muito forte que não existia antigamente. Como, por exemplo, em 2005, quando assumi, tive uma dificuldade absurda de contratar jogadores, pois ninguém queria jogar aqui, uma situação financeira muito ruim. Hoje os jogadores querem vir para o Flamengo, pois o Flamengo tem credibilidade, está pagando em dia, esta pagando suas dividas. Isso para você poder cobrar o profissional, seja atleta ou qualquer profissional você tem que fazer sua parte. Acredito que a credibilidade hoje do clube é um fator muito importante para o clima.

- Você considera o clube aberto a receber e reconhecer as criticas, opiniões e contribuições de seus jogadores?

"Sim, com certeza, ainda mais com o próprio sistema de hoje, sem duvidas".

- Quais as principais características de um líder no seu ponto de vista? (Gestor, técnico, jogador)

"Acredito que o líder já nasce, você tem um dom de ser líder. E antigamente, você comandava na força, e isso acabou hoje em dia. Hoje, é alguém que saiba comandar sem "bater", consegue ser líder conversando, ajudando, o que não era assim antigamente. Você era o xerife, você mandava. $E$ isso, não é mais assim". 
- Quais fatores mais motivam um jogador?

"Eu diria uma coisa mas acho que não devo dizer. Mas veja bem, não é pejorativo, é um direito, como qualquer trabalhador. Mas também, respeito, condições de trabalho. Entretanto, queira ou não salário em dia, não só jogador de futebol, você quer alcançar melhores cargos pois junto vem salários melhores, um incentivo melhor".

- O que mais gera insatisfação para o jogador?

"O contrário de tudo isso que falei, salário, salário atrasado, falta de respeito, condições de trabalho ruins".

\section{Entrevista Fred Luz}

- Qual a importância de uma gestão profissional para um time de futebol? Como impacta o desempenho dentro de campo?

"Em qualquer atividade econômica, empresarial, e o futebol não deixa de ser uma atividade empresarial, organizacional, você ter uma gestão profissional significa estar na busca dos melhores profissionais para executar aquela função do negócio. No caso do futebol, é o desempenho esportivo, a empatia com a torcida, quer dizer, o desenvolvimento da torcida, os fans, que é a grande fonte de recurso do futebol, e de você ir criando uma escola de aprendizado. O profissionalismo diz isso, é uma especialização para determinados assuntos. Quando você fala de uma gestão armadora, você está falando de pessoas que amam aquilo, aquela atividade, mas que não tem a experiência continuada no exercício. Um dos maiores custos do aprendizado é o erro, para você aprender, você comete erros. É assim, na medida em que você tem uma filosofia de administração armadora, você tem um rodízio das pessoas sem criar os degraus necessários de aprendizado. Enquanto quando você tem um profissional em qualquer atividade, esse vai se especializando, vai possuindo uma exposição aos problemas e assim o aprendizado é continuado. Por isso que é melhor sempre, a longo prazo, você ter um profissional cuidando das tarefas do que você ter um armador em qualquer atividade".

- Você acredita que o modelo do clube, associativo, prejudica ou beneficia uma gestão profissional?

"O fato de ser associativo não atrapalha, mas o estatuto do clube provavelmente terá que ser revisto, porque o estatuto do clube prevê ainda uma administração armadora. Então, nesse sentido, atrapalha um pouco sim. O grande desafio é que na medida em que 
você consiga os melhores profissionais, conseguir mantê-los na organização. A rotação da Presidência do clube a cada 3 anos anos, poderia levar a uma instabilidade da equipe profissional. No caso do Flamengo, ainda não está estabelecida, instituímos isso a partir de 2013, e estamos no processo de aprendizado ainda nessa relação entre os dirigentes profissionais e os dirigentes armadores, que são os estatutários. Na verdade, na medida em que o clube for construindo o processo da participação dos armadores em um tipo de conselho de administração, que dá os objetivos, as metas, aprova os orçamentos para que o grupo de executivos profissionais entregue, iremos chegar em um modelo que concilia a questão da propriedade, que é a dos sócios, representados por uma diretoria, uma administração escolhida por eles, com uma equipe profissional. É isso que o Flamengo está tentando montar. Na medida em que seja montado, o fato de ser uma instituição associativa não prejudica em nada".

\section{- Qual é a "Missão e a Visão" do CR Flamengo?}

"O Flamengo ainda não tem. Nós temos uma visão e uma missão, mas ainda não está devidamente aprovada pela diretoria. Nessa administração tentamos fazer os primeiros passos de um planejamento estratégico, o que acabou que não aconteceu. Está nos nossos objetivos a gente fazer essas seções de definição estratégica do Flamengo, aonde você define a missão, a visão, os valores, em 2016, já estamos criando as condições para isso".

\section{- O clube define objetivos estratégicos? Quais são os critérios para se definir?}

"O clube define sim, metas olhando o médio prazo e as metas para o curto prazo, que falamos que é a do próximo exercício. Essa é a segunda onda desse nosso processo de administração do Flamengo. Na primeira onda, entramos em uma casa em chamas e você tem que entrar com o extintor e apagar o incêndio porque se não a casa vai cair. Então, nos primeiros dois anos, foram basicamente apagando incêndios. Hoje, ainda temos algumas brasinhas em algum cantinho o outro. Agora está na hora de reconstruir a casa, muito mais estruturante. Nós já estamos com um processo estruturado de acompanhamento das nossas metas ainda de 2015, já treinamos mais de 100 pessoas para o Flamengo, do grupo profissional para aprenderem a registrar o acompanhamento de seus objetivos. Esses objetivos são os objetivos do Flamengo, que tem objetivos do futebol profissional, objetivos do futebol de base, objetivos da área de finanças, objetivos da área de marketing, objetivos dos esportes olímpicos, aonde que cada diretor dessas áreas conhece seus objetivos, negociou esses objetivos. O departamento de futebol, você desdobra, objetivos que são do técnico, desempenho desportivo, da área de logística, otimização da sistemática de viagens, redução de custos, otimização, conforto para os jogadores. Tem os objetivos das categorias 
de base, formação de atletas de base, número de atletas de base nas seleções das categorias. Como você tem objetivos financeiros, como marketing, você tem uma meta de receitas, tem que ter $X$ milhões de receita de patrocínio, $X$ milhões de receita de sócio torcedor, $\mathrm{X}$ milhões de receita de bilheteria dos jogos e assim você começa a ver que possui uma interligação entre esses objetivos. Na medida em que o time desempenha melhor, você possui uma possibilidade maior de ter rendas de bilheteria maior, tem uma adesão maior de sócio torcedor, na medida em que o time desempenha melhor. É uma coisa puxa a outra, o chamado ciclo positivo, na medida em que você gera mais receita, você consegue ter atletas de melhor qualidade, ou manter esses atletas de melhor qualidade, time desempenha melhor, você consegue mais receitas e vai girando a roda. Mas hoje, já possuímos essas metas todas, e estamos no momento de montar essas metas para 2016 e o orçamento. O orçamento que é uma peça importantíssima de planejamento, onde ali o clube tem quanto ele vai ganhar e onde ele vai gastar o dinheiro para que ele tenha um melhor desempenho".

\section{- Você acredita que todos os jogadores conhecem os objetivos e metas do Clube?}

"Acredito que os jogadores ainda não conhecem, isso ainda não chegou aos jogadores. Isso é muito importante que chegue primeiro aos gestores, diretores. Acho até que os jogadores não precisam conhecer que o Flamengo tem que ganhar tanto. Existem coisas mais importantes que o jogador precisa conhecer, em que estamos montando. Estamos falando, o que considero particular para os jogadores e para o técnico, desempenho esportivo. Estamos montando um centro de excelência e perfomance. $O$ objetivo desse centro é aumentar a performance individual desse atleta. Também, prevenir contusões dos atletas e propiciar que a recuperação do atleta seja muito mais segura e que seja muito mais rápida. Então, um atleta que tem um desempenho de performance melhor, ele vai desempenhar melhor esportivamente. Isso, chegará aos atletas rapidamente. Em relação a isso, contratamos o serviço de um consultor americano, da maior empresa de excelência em performance do mundo, empresa que se chama Exos, que está na seleção da Alemanha desde 2005. Então ele veio aqui, mapeou todos os nossos processos, fez várias críticas e sugestões. A gente visitou o CT do Corinthians na semana passada que está muito na nossa frente em termo da nossa estrutura e da preparação. Portanto, para o jogador vai chegar as metas do jogador, por exemplo, se amanhã você tem uma meta de melhorar sua performance em determinados assuntos, isso envolve a alimentação, a sua preparação, os horários em que você treina, envolve você melhorar determinadas habilidades. Ou seja, você terá metas. As metas esportivas, os jogadores já possuímos, que é ganhar o jogo, sempre tem a meta de ganhar o jogo. $O$ esporte tem essa facilidade, todo 
atleta tem uma meta específica que é o seu bom desempenho na competição e a melhoria, então é muito fácil para um atleta entender isso.

- O clube possui alguma ação de internacionalização da marca?

"Ele tem, ele tem hoje em dia mais uma intenção do que propriamente uma realização, mas por exemplo, o contrato com a Adidas já é uma baita de uma iniciativa porque a Adidas hoje distribui camisas do Flamengo em cerca de 1500 lojas espalhadas pelo mundo. Faz parte do contrato, é uma obrigatoriedade. Então se você for hoje na França, na Alemanha, na China encontrará lojas que vendem camisas do Flamengo. Nós acreditamos que os direitos internacionais da televisão, da propagação do esporte, futebol do Brasil, é muito pouco explorado. É difícil aparecer, mas é uma coisa que tem sido motivo de conversas nossas com a Tv Globo, quem detém os direitos, e é uma coisa que pretendemos melhorar bastante pro futuro. Nós tivemos perto de fazer uma pré-temporada nos EUA, acabou que não conseguimos viabilizar no formato que queríamos, mas vamos fazer, talvez ano que vem já conseguiremos fazer isso. O mercado americano é muito importante para nós. Estamos em uma discussão com um grupo de investidores, que está querendo montar uma liga, estilo Euro Liga, montar uma liga americana envolvendo os EUA, e o Flamengo tem todo o interesse em participar nisso, pois ajuda a propagar a marca do Flamengo. Alem disso, nós desejamos que as nossa divisões de base comece a ter alguns torneios fora do Brasil, já são iniciativas que o Atletico-Pr e o Fluminense já estão na nossa frente nesse sentido".

- Há algum planejamento para o Flamengo ter seu próprio estádio?

"A questão do próprio estádio está no nosso radar. Acredito que mais cedo ou mais tarde o Flamengo vai chegar lá. O que aconteceu com o Flamengo é que ao longo do tempo, ao invés dele ter construído valor, patrimônios, ele construiu dividas. $E$ assim, quem deve e não tem nenhuma certidão de bom pagador, não pode participar de nenhuma concorrência pública. Então, o Flamengo não era elegível a entrar em uma concorrência, por exemplo, para disputar o Maracanã, não tinha o dinheiro, tinha divida, não tinha capacidade de pagar, era reconhecido como mau pagador por não ter as certidões. Essa situação vem mudando, o Flamengo está se capacitando financeiramente, os últimos 2 anos o Flamengo pagou mais de 200 milhões de dívidas. Por exemplo, se um estádio custo 800 milhões, o Flamengo teria condições de pagar, pagando 100 milhões por ano, tem 8 anos, ele conseguiria pagar um estádio. Com um estádio, a arrecadação é bem maior, você tem vários ativos ligados a ter um estádio, como por exemplo, o sócio-torcedor, pontos de relacionamento com os sócios,o fato de o estádio também ser utilizado para outros atividades comerciais. Então, isso já está no radar e o Flamengo já está entrando numa fase 
de se capacitar a ter um estádio. Isso poderá ser o próprio Maracanã, pois tem toda a questão do contrato do consórcio do Maracanã que ele não consegue se viabilizar financeiramente, e no nosso entendimento, o Maracanã não se viabiliza sem o Flamengo. E se o Flamengo fizer um outro estádio sem ser o Maracanã, o que irá acontecer com o Maracanã? Então, essa é a discussão. Já temos alguns sites, grupos financeiros interessados em analisar projetos para o Flamengo, para o estádio".

- Como é feita o alinhamento estratégico e a comunicação entre os departamentos de Marketing, Finanças e Futebol?

"Isso ainda não está completamente integrado, estamos ainda ganhando a dinâmica. Por exemplo, a pré-temporada. O marketing tem um objetivo de fazer uma receita de bilheteria, o futebol tem toda sua estrutura da pré-temporada, mas esse período do ano como não temos jogos de campeonato oficial, estamos usando para fazer alguns amistosos que são extremamente rentáveis para o Flamengo. O clube tem uma característica especial de ser um clube nacional, onde tem torcedor em todos os cantos do pais. Assim, tenho uma grande oferta para fazer uma arrecadação de $X$ milhões de reais em 2 jogos em Teresina, o que é superior ao que ganho no Campeonato Carioca inteiro, então o Flamengo não pode abrir mão de fazer isso, mas tem que combinar o marketing com o diretor de futebol. $O$ marketing não pode ficar marcando partidas para o time de futebol sem estar alinhado, pois, primeiro, tem o objetivo financeiro e o outro tem o objetivo esportivo. Eventualmente, se você vai para gerar receita prejudicando o desempenho esportivo, não vale a pena, então temos que alinhar. Outros exemplos, são ações de jogadores com o sócio torcedor, venda de jogos que poderiam ser no Rio de Janeiro para outros estados. Como, quando tiramos o jogo do Rio de Janeiro e levamos para Brasília, não teríamos a mínima possibilidade de ter a renda que tivemos caso o jogo fosse aqui no Rio, pois aqui temos jogo sempre. $\mathrm{Na}$ medida em que você consegue considere que o Flamengo é realmente um time nacional, você terá que dividir um pouco isso, e assim, você ganha por todos os lados. Você ganha sócio torcedor porque o morador de outros estados sabe que terá jogo lá, aumenta a receita de bilheteria, aumentando essa receita, a gente aumenta a qualificação do time, podendo ter jogadores melhores, com salários melhores, investir mais na infra-estrutura de preparação. E isso ai, ainda não existe essa integração, e não existindo essa integração, os jogadores não entendem porque está tirando o jogo daqui e colocando em Brasilia? "É um transtorno, vou ficar longe da minha família". Então, essa integração, essa interdependência entre as áreas é uma coisa em que temos que evoluir bastante".

- O Flamengo monitora o que os outros clubes estão fazendo para atingir melhores resultados? De que maneira? 
"Sim, monitora. Visitamos o CT do Corinthians, semana que vem vamos visitar o CT do Atlético-PR. Essa empresa americana que estamos querendo contratar, enviaram uma proposta para trabalhar com a gente, já trabalham com o Atletico-PR desde janeiro. Estamos indo para ver, para aprender com eles. Toda essa nossa intenção de rever os processos das categorias de base começaram com uma visita que eu e o Fernando Gonçalvez fizemos ao Atletico-PR. Para mim, o Atletico é o melhor do Brasil em termo de geração de atleta de valor, se você for pegar a lista de jogadores brasileiros que tem valor alto fora do Brasil, uma grande parte passou pelo Atlético-PR, Internacional e Santos, esses são benchmarketing nessas áreas.

- De que maneira o clube monitora as ações da CBF?

"O presidente do Flamengo, assim como eu, vamos normalmente lá. Tem o lado das competições em si que são gerenciados pela CBF e pelas Federações Estaduais. Tem uma questão de regulamentação. No nosso entendimento, a estrutura de poder das Federações Estaduais está equivocado, temos que mudar isso, e isso se muda via Congresso Nacional, muito complexo e que tem a ver com a Lei Pelé, mudanças nessa lei. Dado que existe a Federação, a governança da Federação, o Flamengo atua para respeitar as regras, as regulamentações, os registros de jogadores, competições, as programações dos jogos. $E$ como membro dessas agremiações, o Flamengo também atuar de uma forma colaborativa, trazendo uma visão mais responsável, mais profissional para que essas entidades atuam dessa forma. É tudo interdependente".

- Como o clube monitora a satisfação e os desejos de seus torcedores/ clientes?

"Nós não temos muitas medidas ainda. Temos algumas pesquisas junto ao sócio torcedor, temos uma sensibilidade da pesquisa da torcida e fizemos ano passado uma pesquisa com os sócios do clube, que é o fórum de propriedade do grupo e quem elege. Como eles vem a Gavea? O que gostariam de ter de serviço aprimorados na Gavea? Para que a gente possa oferecer esses serviços. No caso do torcedor, existe institutos de pesquisa que fazem analises e observamos, que são o Pay per view, a gente recebe uma remuneração da Globo pelo Pay per view. E tem uma pesquisa regular que a Globo faz de evolução do Pay per view, quais clubes que estão evoluindo mais ou menos, e o Flamengo é o líder que mais tem crescido. A gente tem medidas que aparecem sobre crescimento de torcida por faixa etária, temos uma preocupação muito grande da nossa participação no público mais jovem, pois esse é a torcida do futuro. E o percentual de rubro negros nas faixas mais jovens é maior que o percentual das faixas mais velhas e isso significa que a nossa torcida está crescendo". 
- Como funciona o programa de sócio torcedor? O que fazer para continuar vendendo mesmo se o time não obtiver bons resultados em campo?

"Nós temos um foco muito grande no programa de sócio torcedor do Benfica, que o Internacional faz algumas coisas parecidas com que o Benfica fez, aqui no Brasil. A relação do sócio torcedor com o clube se da na medida em que ele consiga ter uma relação com o clube próximo da onde ele vive. Então, imagina o cara que mora em Manaus, onde mais de $50 \%$ da população é Flamengo, quase não tem jogo do Flamengo lá. Então, ele vai em um bar, ou algo do tipo para assistir os jogos. Dessa forma, o Flamengo tem que começar a criar uns ambientes do Flamengo em que o cara vá, e ai que eu consiga em uma Tv digital colocar os jogadores se comunicando de alguma forma com esses torcedores. E assim, o cara vai querer ir mais a esse bar do que a um bar comum, pois é um bar onde ele interage com o Flamengo. E assim, para ele ir, ele terá que ser sócio torcedor, e sendo sócio ele tem descontos, mesmo ele não tendo o jogo, ele tem a relação. Porque nem sempre se precisa estar ganhando para ter a relação. Agora, quando você não tem uma forma estruturada de ter essa relação, só sobra o jogo, e com isso, o resultado esportivo tem uma interferência direta nesse processo. Então, nossa visão é um clube de descontos, associado a pontos de relacionamento que vão alavancar o sócio torcedor. Estamos criando um instrumento básico de relacionamento que é um cartão pré-pago, que devemos lançar ainda esse ano, para todos os torcedores do Flamengo terem acesso, mesmo não sendo sócio torcedor.Com esse cartão, poderemos estabelecer um programa de milhagem, na medida que a pessoa faz transações com aquele cartão, ele começa a ter um bônus, ele pode até pagar o programa sócio torcedor com esse bônus. E a gente vai começar a montar redes de descontos regionais, em que a pessoa vai com aquele cartão, por exemplo, se for em uma drogaria com aquele cartão, ele terá desconto. Dessa forma, o Flamengo terá parcerias com as entidades comerciais. O Benfica fez, por exemplo, com uma rede de postos de gasolina, então a pessoa vai abastecer e terá desconto, com isso, já poderá pagar o programa de sócio torcedor dele.

- Como você considera o relacionamento entre os jogadores?

"Eu não interajo muito com os jogadores, tenho mais relação com o Rodrigo (diretor executivo), com o técnico e comissão técnica. Então, o que eu percebo é a partir dessas conversas que eu tenho com eles. $E$ assim, eu me baseio na opinião dessas pessoas. $O$ que eu acho que o Flamengo deverá desenvolver, também, é uma relação mais comercial com esses jogadores. O Flamengo detém o direito de imagem dos jogadores, e acredito que existe um espaço enorme para o Flamengo explorar isso em beneficio do clube e também dos jogadores. Porque a medida em que o jogador tenha um retorno comercial pelo fato de estar jogando no Flamengo, isso capacita o Flamengo a ter melhores jogadores, pois na 
hora em que o jogador for ver se vale a pena ou não trabalhar no clube, ele não vai olhar apenas o salário, vai o olhar o salário e mais os outros benefícios que você possa ter comerciais dessa relação. Diria que o Flamengo está hoje no começo do começo de uma visão estruturada que nunca fez.

- Quais os principais fatores que impactam o clima organizacional do clube?

"Acredito que o clima organizacional do Flamengo é bom, hoje o Flamengo tem um espírito de pessoas que são serias e corretas e que falam a verdade entre elas. Essa transição demora um pouco. Hoje em dia, todo mundo está focado em trabalhar com objetivos claros, cada vez mais esses objetivos estão sendo mais estruturados. Aqui no futebol, temos mais de 40 pessoas nesse processo de monitoramento de objetivos. Então, isso vai tornando a conversa mais real, e nós estamos aqui um para ajudar o outro. $\mathrm{Na}$ medida em que você tem um problema que não consiga resolver, o teu supervisor ou seu colega podem vir te ajudar a fazer. Mas falando claramente: "se você tomou um frango, você tomou um frango", a conversa não é se não falhou ou se falhou, a conversa que vale mais é: o que vou fazer para não falhar da próxima vez? Isso é o que gera o aprendizado. Então, um clima organizacional tem que estar sempre associado a gente conseguir enxergar onde estão as nossas oportunidades de melhoria, que significa onde estão minhas oportunidades de aprendizado, só assim que eu consigo evoluir. Acredito que a transparência, a honestidade, sinceridade são a mola mestra de um relacionamento saudável entre as pessoas".

- Você considera o clube aberto a receber e reconhecer as criticas, opiniões e contribuições de seus jogadores?

"Acredito que sim, mas não sei. Não sei como a comissão técnica, o treinador vêem isso. Mas acredito que se não é, deveria ser".

- Quais as principais características de um líder no seu ponto de vista? (Gestor, técnico, jogador)

"Conseguir passar com muita clareza quais são os objetivos coletivos e individuais, mas no fundo a missão, a visão, as metas. Segundo, ser um grande motivador, para tirar o melhor de cada pessoa. Acredito que as pessoas que se desenvolvem, não sou eu quem desenvolvo você, mas eu posso criar condições estimulantes para você se desenvolver. E condições estimulantes nem sempre é ser bonzinho com você, é passar a realidade como ela é, e assim, te estimular da seguinte forma, tem pontos a serem melhorados no seu desempenho. Então, esse acompanhamento, essa conversa verdadeira, acredito que 
estimula muito. Fundamentalmente, um líder também cria uma relação de confiança com seus liderados. Portanto, diria que é isso, passar os objetivos, motivar e acompanhar.

- Quais fatores mais motivam um jogador?

"Pessoalmente, o que mais motiva uma pessoa é ela perceber que ela está evoluindo e que está também em um grupo que é vencedor, que tem chances de ser vencedor. Se estiver em um ambiente onde você pense que o seu potencial não esteja sendo totalmente aproveitado, explorado e eu estou em um grupo perdedor, acredito que haverá uma baixa motivação. Caso contrário, onde o grupo é ótimo e eu conto, tenho desafios, estou melhorando, acredito que é o melhor lugar para estar.

- O que mais gera insatisfação para o jogador?

"Acredito que primeiro é não estar ganhando, o segundo não estar sendo reconhecido como ele acha que deveria estar sendo dentro daquele ambiente".

\section{Entrevista Oswaldo de Oliveira}

- Qual a importância de uma gestão profissional para um time de futebol? Como impacta o desempenho dentro de campo?

"Hoje em dia é fundamental, o futebol evoluiu muito principalmente nas questões administrativas. As disciplinas que envolvem o futebol são muitas e elas precisam ser administradas, geridas. E atuem de forma homogênea para fazer o futebol funcionar. Se nos pensarmos no futebol a 40 anos atrás, hoje é tudo diferente como era aquela época. As interferências buscando performance são cada vez melhores, cada vez mais com interferência da tecnologia. Houve um crescimento muito grande no aspecto de marketing e financeiro. Então, isso exige pessoas especializadas que conheçam não so o futebol mas todos esses detalhes que estão na orbita do futebol e sejam administrados. E então indo de encontro com a palavra, sendo geridas. Isso é importante pois interfere diretamente no desempenho dentro de campo. Se você conjugar a qualidade do jogador, do elenco, com a qualidade do trabalho que é feito em prol da performance do atleta, através da comissão técnica e os vários profissionais. Isso tudo conjugado na direção da performance tem um crescimento muito grande. Precisa-se realmente que haja uma administração, um conselho ou individuo gestor para dar essas condições. Estamos observando no futebol mundial que as equipes que tem esse processo já bem desenvolvido, estão mais próximos das vitorias. 
- Você acredita que o modelo do clube, associativo, prejudica ou beneficia uma gestão profissional?

"Há de se evoluir muito nas duas direções. O Flamengo é um caso a parte, pois é uma nação, é um clube que gera muito notícia, muito marketing, muita emoção, é uma massa muito grande para ser administrada. Então, precisamos ter consenso, aonde as duas evoluam homogêneas e na mesma proporção para que não haja disparidades".

- Você acredita que todos os jogadores conhecem os objetivos e metas do Clube?

"De forma geral sim. Ocorre que as mudanças são muito grandes, os elencos são mutáveis, a cada ano, as vezes nem anualmente, semestralmente jogador se vão e vem. Isso se torna esse conhecimento muito limitado. Os que permanecem mais tempo e conseguem transmitir aos companheiros, facilita muito".

- O clube passa claramente e objetivamente as tarefas a serem cumpridas pelos jogadores?

"Ainda não, nos estamos no caminho. O Flamengo está procurando evoluir, se desenvolvendo em seus diversos setores para que isso aconteça".

- O Flamengo monitora o que os outros clubes estão fazendo para atingir melhores resultados? De que maneira?

"Sim, estou aqui há 2 meses e tenho visto uma preocupação muito grande dos gestores do Flamengo, em seus níveis, procurando dar as melhores condições. E uma delas é procurando ter conhecimento do que se passa nos outros clubes também".

- Como você considera o relacionamento entre os jogadores?

"Muito bom. No Flamengo vemos uma coisa que nem em todo clube tem, um grande indicador disso é que nas concentrações, quando acaba as refeições, fica um grande numero de jogadores conversando, trocando idéias. Nem todo o clube tem essa prática, e acho isso muito importante".

- E o relacionamento entre dirigente/ comissão técnica e jogador?

"Excelente, vem melhorando a cada dia. Cheguei a pouco tempo, mas encontrei muita receptividade. E estou procurando retribuir".

- Quais os principais fatores que impactam o clima organizacional do clube?

"No Flamengo, é claro que é a torcida. A importância da torcida para o Flamengo é fundamental. Haja visto que o clube não vem em uma boa posição no campeonato e o 
Maracanã vive cheio. Fomos para Natal, Brasília e lotou os estádios. Em qualquer lugar que o Flamengo vai, sempre é um atrativo muito grande. Acho que isso é o fundamento do Flamengo e tudo deve se voltar para isso, uma administração que gere uma melhora técnica, melhora financeira, melhora administrativa, de marketing, tudo tem que ser fundamentado nessa massa enorme que o Flamengo tem."

- Você considera o clube aberto a receber e reconhecer as criticas, opiniões e contribuições de seus jogadores?

"Com certeza é sim. Alias, o Flamengo é o maior alvo de criticas e êxtase de emoção também, por ser esse atrativo enorme. O Flamengo tem procurado em seus departamentos, através de sócio torcedor, indiretamente através de suas torcidas. Os departamentos do clube tem procurado dar condições para que isso aconteça".

- Quais as principais características de um líder no seu ponto de vista? (Gestor, técnico, jogador)

"Principalmente tem que ser uma pessoa digna, para ter uma liderança, uma direção favorável a todo o grupo. Liderar não é fácil e ao mesmo tempo é um dom. Mesmo sendo uma aptidão, você pode desenvolver, melhorar isso. Então deve ser uma busca muito grande que essa liderança cresça e procure atuar realmente de uma forma positiva no grupo".

- Quais fatores mais motivam um jogador?

"Os jogadores são diferentes e tem motivações diferentes. Mas, vejo que o amor por aquilo que ele faz, o prazer de jogar futebol, de buscar vitorias é a grande motivação".

- O que mais gera insatisfação para o jogador?

"Acredito que tenha varias coisas que geram insatisfação em um jogador. Hoje, no esquema profissional, acredito que quando um arbitro erra injustamente e altera muito em um resultado do jogo, salários atrasados também mexem muito e também as concentrações são bem desagradáveis para quem joga 70 vezes por ano, é uma rotina bem desagradável". 